LBNL-53605

\title{
Duct Leakage Impacts on VAV System \\ Performance in California Large Commercial Buildings
}

\author{
Craig P. Wray and Nance E. Matson \\ Environmental Energy Technologies Division \\ Indoor Environment Department \\ Lawrence Berkeley National Laboratory \\ Berkeley, CA 94720
}

October 2003

This report describes work supported by the California Energy Commission through the Public Interest Energy Research program under contract no. 400-99-012-1, and by the Assistant Secretary for Energy Efficiency and Renewable Energy, Building Technologies Program, U.S. Department of Energy under contract no. DE-AC03-76SF00098. 
The Lawrence Berkeley National Laboratory, 1 Cyclotron Road, Berkeley, CA 94720 is a national laboratory of the U.S. Department of Energy managed by the Regents of the University of California for the U.S. Department of Energy under Contract Number DEAC03-76SF00098. This report was prepared as a result of work sponsored by the California Energy Commission (Commission). It does not necessarily represent the views of the Commission, its employees, or the State of California. The Commission, the State of California, its employees, contractors, and subcontractors make no warranty, express or implied, and assume no legal liability for the information in this report, nor does any party represent that the use of this information will not infringe upon privately owned rights. This report has not been approved or disapproved by the Commission nor has the Commission passed upon the accuracy or adequacy of the information in this report.

THE GOVERNMENT AND THE CONTRACTOR MAKE NO EXPRESS OR IMPLIED WARRANTY AS TO THE CONDITIONS OF THE RESEARCH OR ANY INTELLECTUAL PROPERTY, GENERATED INFORMATION, OR PRODUCT MADE OR DEVELOPED UNDER THIS AGREEMENT, OR THE OWNERSHIP, MERCHANTABILITY, OR FITNESS FOR A PARTICULAR PURPOSE OF THE RESEARCH OR RESULTING PRODUCT; THAT THE GOODS, SERVICES, MATERIALS, PRODUCTS, PROCESSES, INFORMATION, OR DATA TO BE FURNISHED HEREUNDER WILL ACCOMPLISH INTENDED RESULTS OR ARE SAFE FOR ANY PURPOSE INCLUDING THE INTENDED PURPOSE; OR THAT ANY OF THE ABOVE WILL NOT INTERFERE WITH PRIVATELY OWNED RIGHTS OF OTHERS. NEITHER THE GOVERNMENT NOR THE CONTRACTOR SHALL BE LIABLE FOR SPECIAL, CONSEQUENTIAL, OR INCIDENTAL DAMAGES ATTRIBUTED TO SUCH RESEARCH OR RESULTING PRODUCT, INTELLECTUAL PROPERTY, GENERATED INFORMATION, OR PRODUCT MADE OR DELIVERED UNDER THIS AGREEMENT. 


\section{ACKNOWLEDGEMENTS}

The largest debt of gratitude goes to former and current Energy Performance of Buildings staff members: Ellen Franconi (Nexant Corporation) for her development of the DOE-2/TRNSYS modeling approach and for implementing the duct models in a form that could readily be used in this project; and Brian Smith (LBNL) for computer applications support throughout the project.

LBNL staff members in the Building Technologies Department were also helpful and supportive of this work, particularly regarding the intricacies of DOE-2.1E. The authors wish to thank Joe Huang, Fred Winkelmann, and Fred Buhl.

Advice of Michaël Kummert at the Solar Energy Laboratory, University of Wisconsin-Madison regarding TRNSYS compiling issues was greatly appreciated.

This project evolved from the ideas and work of Mark Modera (LBNL), who was the original project lead. Even after he left the project, Mark continued to provide contributions and was a valuable resource for the project team.

Finally, the authors would like to acknowledge the support and contributions of the PIER Contract Manager, Martha Brook, and the Buildings Program team under the leadership of Nancy Jenkins. 


\section{TABLE OF CONTENTS}

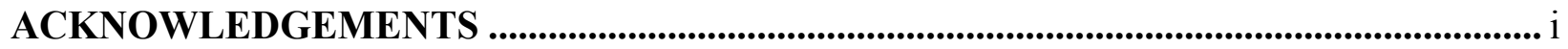

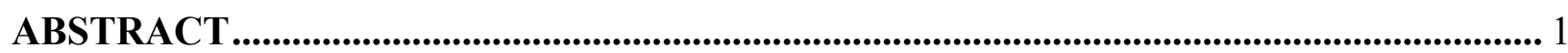

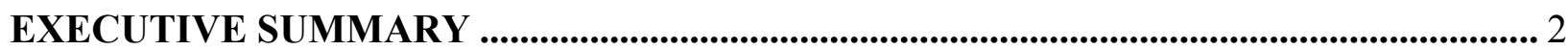

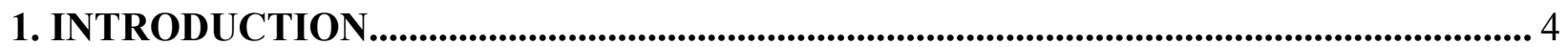

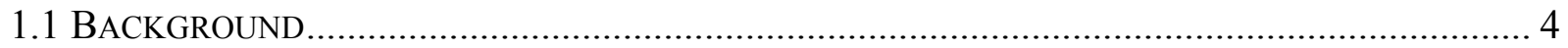

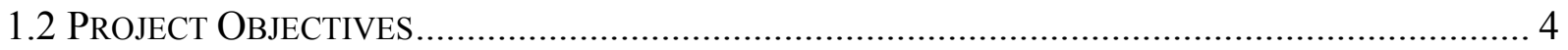

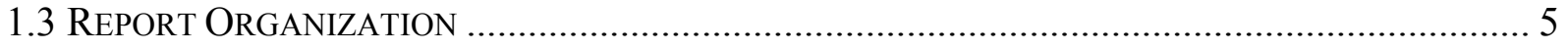

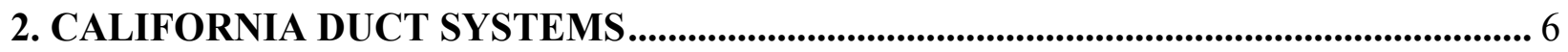

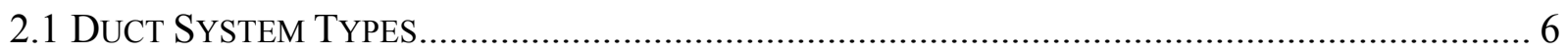

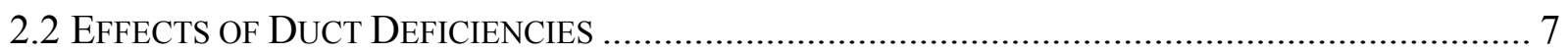

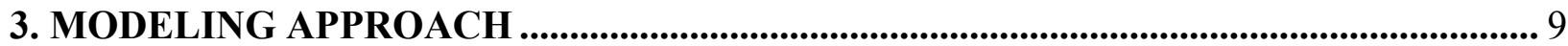

4. BUILDING AND HVAC SYSTEM CHARACTERISTICS ................................................ 10

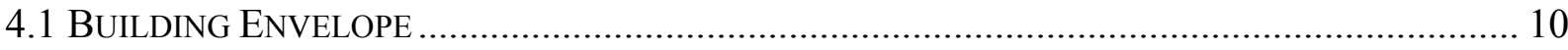

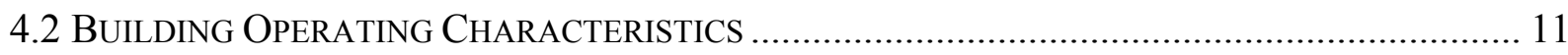

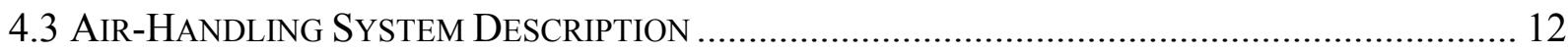

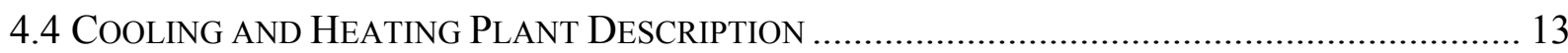

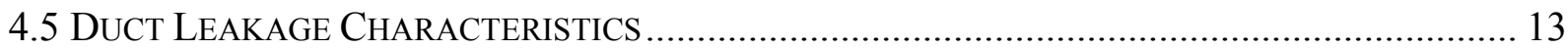

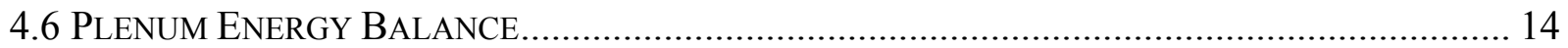

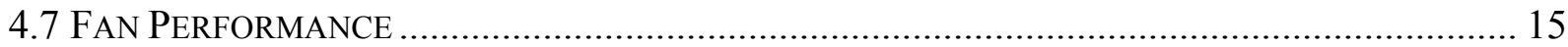

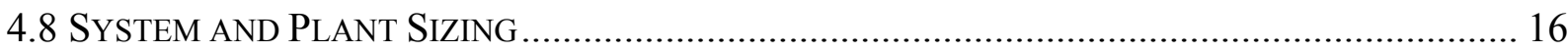

5. SYSTEM - PLANT ENERGY USE REGRESSIONS ........................................................... 18

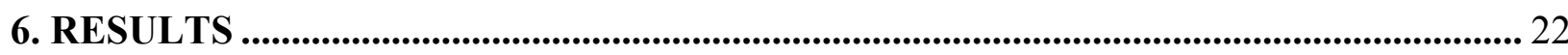

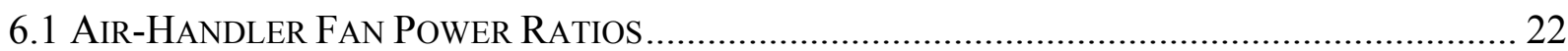

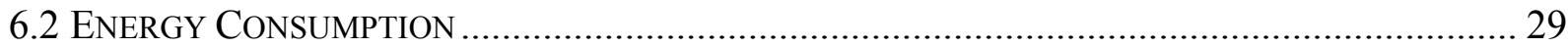

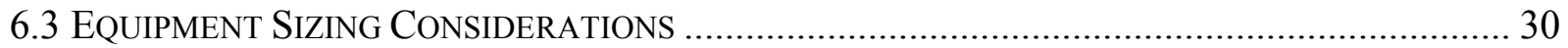

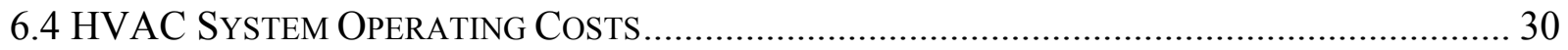

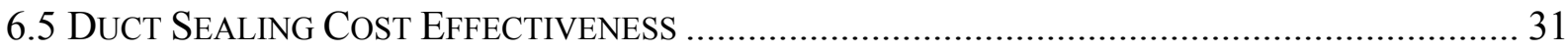

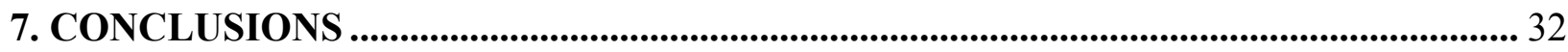

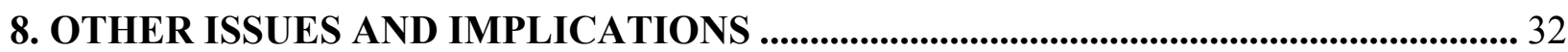

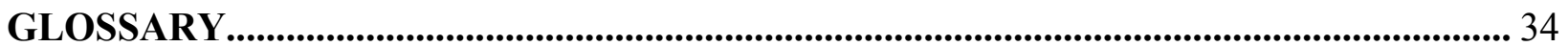

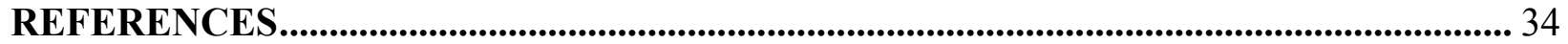

APPENDIX I: BUILDING SCHEDULES.................................................................................... 37

APPENDIX II: REGRESSION EQUATIONS AND COEFFICIENTS ............................... 40

APPENDIX III: ENERGY PERFORMANCE IMPACTS.......................................................... 46

APPENDIX IV: EQUIPMENT SIZING IMPACTS .................................................................. 49

APPENDIX V: OPERATING COST IMPACTS .................................................................. 51 


\section{ABSTRACT}

The purpose of this study is to evaluate the variability of duct leakage impacts on air distribution system performance for typical large commercial buildings in California. Specifically, a hybrid DOE-2/TRNSYS sequential simulation approach was used to model the energy use of a lowpressure terminal-reheat variable-air-volume (VAV) HVAC system with six duct leakage configurations (tight to leaky) in nine prototypical large office buildings (representing three construction eras in three California climates where these types of buildings are common). Combined fan power for the variable-speed-controlled supply and return fans at design conditions was assumed to be $0.8 \mathrm{~W} / \mathrm{cfm}$.

Based on our analyses of the 54 simulation cases, the increase in annual fan energy is estimated to be 40 to $50 \%$ for a system with a total leakage of $19 \%$ at design conditions compared to a tight system with 5\% leakage. Annual cooling plant energy also increases by about 7 to $10 \%$, but reheat energy decreases (about 3 to 10\%). In combination, the increase in total annual HVAC site energy is 2 to $14 \%$. The total HVAC site energy use includes supply and return fan electricity consumption, chiller and cooling tower electricity consumption, boiler electricity consumption, and boiler natural gas consumption.

Using year 2000 average commercial sector energy prices for California $(\$ 0.0986 / \mathrm{kWh}$ and $\$ 7.71 /$ Million Btu), the energy increases result in 9 to $18 \%(\$ 7,400$ to $\$ 9,500)$ increases in HVAC system annual operating costs. Normalized by duct surface area, the increases in annual operating costs are 0.14 to $0.18 \$ / \mathrm{ft}^{2}$. Using a suggested one-time duct sealing cost of $\$ 0.20$ per square foot of duct surface area, these results indicate that sealing leaky ducts in VAV systems has a simple payback period of about 1.3 years. Even with total leakage rates as low as $10 \%$, duct sealing is still cost effective. This suggests that duct sealing should be considered at least for VAV systems with $10 \%$ or more total duct leakage.

The VAV system that we simulated had perfectly insulated ducts, and maintained constant static pressure in the ducts upstream of the VAV boxes and a constant supply air temperature at the airhandler. Further evaluations of duct leakage impacts should be carried out in the future after methodologies are developed to deal with duct surface heat transfer effects, to deal with airflows entering VAV boxes from ceiling return plenums (e.g., to model parallel fan-powered VAV boxes), and to deal with static pressure reset and supply air temperature reset strategies. 


\section{EXECUTIVE SUMMARY}

Introduction. Despite the potential for significant energy savings by reducing duct leakage or other thermal losses from duct systems in large commercial buildings, California Title 24 has no provisions to credit energy efficient duct systems in these buildings. A substantial reason is the lack of readily available simulation tools to demonstrate the energy saving benefits associated with efficient duct systems in large commercial buildings. A related reason is that, although substantial energy increases due to duct leakage have been identified by recent field work and simulations, the variability of these impacts for the different building vintages and climates in California has not been established.

Purpose. The overall goal of the Efficient Distribution Systems (EDS) project within the PIER High Performance Commercial Building Systems Program is to bridge the gaps in current duct thermal performance modeling capabilities, and to expand our understanding of duct thermal performance in California large commercial buildings. As steps toward this goal, our strategy in the EDS project involves two parts: 1) developing a whole-building energy simulation approach for analyzing duct thermal performance in large commercial buildings, and 2) using the tool to identify the energy impacts of duct leakage in California large commercial buildings, in support of future recommendations to address duct performance in the Title 24 Energy Efficiency Standards for Nonresidential Buildings.

Objectives. The specific technical objectives for the EDS project were to:

1. Identify a near-term whole-building energy simulation approach that can be used in the impacts analysis task of this project (see Objective 3), with little or no modification. A secondary objective is to recommend how to proceed with long-term development of an improved compliance tool for Title 24 that addresses duct thermal performance.

2. Develop an Alternative Calculation Method (ACM) change proposal to include a new metric for thermal distribution system efficiency in the reporting requirements for the 2005 Title 24 Standards. The metric will facilitate future comparisons of different system types using a common "yardstick".

3. Using the selected near-term simulation approach, assess the impacts of duct system improvements in California large commercial buildings, over a range of building vintages and climates. This assessment will provide a solid foundation for future efforts that address the energy efficiency of large commercial duct systems in Title 24.

This report presents findings and recommendations that resulted from our modeling efforts related to duct thermal performance (Objective 3).

Outcomes. There are two principal outcomes from the work reported here:

Uniformity of Duct Leakage Impacts: A hybrid DOE-2/TRNSYS sequential simulation approach was used to model the energy use of a low-pressure terminal-reheat variable-air-volume HVAC system with six duct leakage configurations (tight to leaky) in nine prototypical large office buildings (representing 1980s, 1990s, and 2005 construction eras in three California climates where these types of buildings are common - Oakland, Pasadena, and Sacramento). Combined fan power for the variable-speed-controlled supply and return fans at design conditions was assumed to be $0.8 \mathrm{~W} / \mathrm{cfm}$.

Based on our analyses of the 54 simulation cases, we conclude that there can be substantial energy impacts due to duct leakage in this type of building. This finding is consistent with recent 
field measurements in a large office building in Sacramento. Our analyses indicate that a leaky VAV system (19\% total duct leakage) will use about 40 to $50 \%$ more fan energy annually than a tight system with 5\% leakage. Annual cooling plant energy also increases by about 7 to $10 \%$, but reheat energy decreases (about 3 to 10\%). In combination, the increase in total annual HVAC site energy is 2 to $14 \%$. The total HVAC site energy use includes supply and return fan electricity consumption, chiller and cooling tower electricity consumption, boiler electricity consumption, and boiler natural gas consumption.

Using year 2000 average commercial sector energy prices for California $(\$ 0.0986 / \mathrm{kWh}$ and $\$ 7.71 /$ Million Btu), the energy increases result in 9 to $18 \%(\$ 7,400$ to $\$ 9,500)$ increases in HVAC system annual operating costs. Our simulations also indicate that climate and building vintage differences do not cause significant variability in duct leakage impacts on fan energy use or on operating cost for leaky duct systems. This suggests that a single duct leakage threshold could be developed for use in the Title 24 prescriptive compliance approach and would not need to be climate or building age specific.

Duct Sealing is Cost Effective: Normalized by duct surface area, the increases in HVAC system annual operating costs are 0.14 to $0.18 \$ / \mathrm{ft}^{2}$ for the $19 \%$ leakage case. Using a suggested onetime duct sealing cost of $\$ 0.20 / \mathrm{ft}^{2}$ of duct surface area, these results indicate that sealing leaky ducts in VAV systems has a simple payback period of about 1.3 years. Even with total leakage rates as low as $10 \%$, duct sealing is still cost effective. This suggests that duct sealing should be considered at least for VAV systems with $10 \%$ or more total duct leakage.

Recommendations. Before duct performance in large commercial buildings can be accounted for in Title 24 nonresidential building energy standards, there are several issues that must be addressed and resolved. These include:

1. Specifying reliable duct air leakage measurement techniques that can be practically applied in the large commercial building sector.

2. Defining the duct leakage condition for the standard building used in Title 24 compliance simulations.

3. Assuring consistency between simulated duct performance impacts and actual impacts.

4. Developing compliance tests for the Alternative Calculation Method (ACM) Approval Manual (CEC 2001b) to evaluate duct performance simulations.

Three additional steps will be required to further develop duct-modeling capabilities that address limitations in existing models and to initiate strong market activity related to duct system improvements. We recommend that these steps include:

1. Implementing duct models in user-friendly commercially-available software for building energy simulation, validating the implementations with case studies and demonstrations, and obtaining certification for software use as a primary or alternative compliance tool in support of the Title 24 Nonresidential Standards.

2. Developing methodologies to deal with airflows entering VAV boxes from ceiling return plenums (e.g., to model parallel fan-powered VAV boxes), to deal with duct surface heat transfer effects, and to deal with static pressure reset and supply air temperature reset strategies.

3. Transferring information to practitioners through publications, conferences, workshops, and other education programs. 


\section{INTRODUCTION}

\subsection{Background}

Previous research suggests that duct systems in California commercial buildings suffer from a number of problems, such as thermal losses due to duct air leakage. For example, measurements by Diamond et al. (2003) in a large commercial building confirmed predictions by Franconi et al. (1998) that duct leakage can significantly increase HVAC system energy consumption: adding $15 \%$ duct leakage at operating conditions leads to a fan power increase of 25 to $35 \%$. Diamond et al. also estimated that eliminating duct leakage airflows in half of California's existing large commercial buildings has the potential to save about 560 to $1,100 \mathrm{GWh}$ annually $(\$ 60-\$ 110$ million per year or the equivalent consumption of 83,000 to 170,000 typical California houses), and about 100 to $200 \mathrm{MW}$ in peak demand.

California Title 24, Part 6 (CEC 2001a) is one of the most advanced energy codes in the United States. The impacts of duct thermal performance in residences are already addressed by Title 24 compliance procedures; duct-system energy efficiency requirements have recently been added for small commercial buildings with individual packaged equipment serving 5,000 $\mathrm{ft}^{2}$ or less where ducts are located in spaces between insulated ceilings and the roof, or outside the building; and new requirements for duct performance in other small commercial buildings are being developed. However, despite the potential for significant energy savings by reducing thermal losses from duct systems in large commercial buildings, Title 24 has no provisions to credit energy efficient duct systems in these buildings. A substantial reason is the lack of readily available simulation tools to demonstrate the energy saving benefits associated with efficient duct systems in large commercial buildings. A related reason is that, although substantial energy increases due to duct leakage have been identified, the variability of these impacts for the different building vintages and climates in California has not been established.

\subsection{Project Objectives}

The work reported here is part of the Efficient Distribution Systems (EDS) project within the PIER High Performance Commercial Building Systems Program. The EDS project goal is to bridge the gaps in duct system modeling capabilities, and to expand our understanding of duct thermal performance in California's large commercial buildings, by following through on the strategy outlined by Xu et al. (1999). As steps toward this goal, the project involves three specific technical objectives:

1. Identify a near-term whole-building energy simulation approach that can be used in the impacts analysis task of this project (see Objective 3), with little or no modification. A secondary objective is to recommend how to proceed with long-term development of an improved compliance tool for Title 24 that addresses duct thermal performance.

2. Develop an Alternative Calculation Method (ACM) change proposal to include a new metric for thermal distribution system efficiency in the reporting requirements for the 2005 Title 24 Standards. The metric will facilitate future comparisons of different system types using a common "yardstick".

3. Using the selected near-term simulation approach, assess the impacts of duct system improvements in California large commercial buildings, over a range of building vintages and climates. This assessment will provide a solid foundation for future efforts that address the energy efficiency of large commercial duct systems in Title 24. 
In support of Objective 1, Wray (2003) carried out a review of documents related to past HVAC system modeling efforts, which was supplemented by discussions with other simulation experts. Based on that work, he defined a set of modeling principles and published HVAC component models that can be used to guide duct thermal performance modeling for large commercial buildings. He also suggested that the best short-term approach for evaluating duct leakage impacts on HVAC system performance is to build upon past research that used DOE-2 and TRNSYS sequentially (Franconi 1999).

However, Wray (2003) concluded that DOE-2 is not a suitable platform for the long-term development of models to address duct system performance in large commercial buildings. $\mathrm{He}$ suggested instead that EnergyPlus, which is based in part on DOE-2, be developed to include component models like the TRNSYS ones identified for use in this project's duct leakage impact analysis task. Although EnergyPlus has no duct performance models, we expect that the recommended enhancements could be applied in a relatively straightforward manner.

Regarding Objective 2, the California Energy Commission has accepted the ACM change that Modera (2002) proposed for the 2005 Title 24 Standards to address HVAC distribution system efficiency in large commercial buildings. The metric of interest, HVAC Transport Efficiency, characterizes the overall efficiency of the thermal distribution system as the ratio between the energy expended to transport heating, cooling, and ventilation throughout a building and the total thermal energy delivered to the various conditioned zones in the building. Since the proposal is for a set of reporting changes, the ACM proposal should not require significant effort on the part of ACM providers to implement the changes in existing Title 24 non-residential compliance software.

Objective 3 is the focus of the work reported here. In particular, this report presents findings and recommendations that resulted from our modeling efforts to assess the impacts of duct thermal performance improvements.

This project contributes to the PIER program objective of improving the energy cost and value of California's electricity in two ways. One is by developing analytical methods to show that well designed duct systems in large commercial buildings can save much of the energy used to move and condition air. The other is by making progress toward new requirements for commercial duct system efficiency in future revisions of Title 24 . We expect that the new analytical capabilities and performance requirements will ultimately result in smaller capacity, more energy-efficient building systems, which will also reduce peak electrical demand from California's commercial building sector and improve the reliability and quality of California's electricity.

\subsection{Report Organization}

In Section 2, California Duct Systems, we briefly describe duct system types that are common in California large commercial buildings, and present an example to illustrate the effects of duct system deficiencies.

In Section 3, Modeling Approach, we summarize the DOE-2/TRNSYS simulation approach that we used to evaluate the impacts of duct leakage on VAV system performance.

In Section 4, Building and HVAC System Characteristics, we describe the characteristics of the prototypical large office building that we simulated, and summarize the 54 building vintage, climate, and duct leakage combinations that we used in this study. 
In Section 5, System - Plant Energy Use Regressions, we summarize our approach to translate TRNSYS air-handling system coil loads into cooling and heating plant energy use.

In Section 6, Results, we describe the impacts of duct leakage on building energy performance, based on the simulation results. To improve readability, the large data tables referred to in this section are located after the References section.

In Section 7, Conclusions, we present what we learned from the research.

In Section 8, Other Issues and Implications, we recommend future activities.

Following the Glossary and References, there are two Appendices:

"Appendix I, Building Schedules" lists the various operating schedules that we used in the simulations.

“Appendix II, Regression Equations and Coefficients" provides details about the system plant energy use regressions that we developed, and explains how they are used.

\section{CALIFORNIA DUCT SYSTEMS}

The information in this section briefly describes duct system types that are common in California large commercial buildings, and presents an example to illustrate the effects of duct system deficiencies. The intent of this section is to help the reader understand why we simulated VAV systems in large office buildings and to conceptualize how duct leakage can affect the performance of an HVAC system.

\subsection{Duct System Types}

Using survey data collected from 1988 through 1993 by or for California utilities and for the California Energy Commission, Modera et al. (1999) determined that there are three basic types of duct systems in California commercial buildings:

- Single-duct systems generate either a cool or warm air stream at the air-handler. The supply air is delivered to the conditioned zones through a single duct system connected to the air-handler. Reheat coils at individual terminal units can be used to add heat to the supply air when needed.

- Dual duct systems generate a cool air stream and a warm air stream at the air-handler. Each air stream is supplied to terminal boxes through a separate duct system. The terminal boxes mix the air streams before the supply air enters the zones.

- Multizone duct systems also generate a cool air stream and a warm air stream at the airhandler, but they use dampers at the air-handler instead of at a terminal box to mix the cool and warm air streams for each zone. Each zone's supply air is delivered through a separate duct system (this system is somewhat like several single-duct systems operating in parallel).

All of these duct systems use one of two methods to control the amount of energy supplied to each zone. A constant-air-volume ( $C A V$ ) system delivers a fixed quantity of supply air to the conditioned space and maintains desired conditions by varying the temperature of the supply air. A variable-air-volume ( $V A V)$ system maintains space temperature by varying the quantity of supply air, generally at a fixed temperature. 
Based on the floor area served by these duct systems (Modera et al. 1999), the most common system across different California building types is the single duct CAV system (71\%). The next most common system type is the multizone system (19\%). Single-duct VAV systems (8\%) and dual duct systems $(2 \%)$ serve the remainder of the floor area. Note that the fraction of multizone systems might be overrepresented by these data. Modera et al. indicated that the survey data may include some inappropriate affirmative responses for multizone systems. In some cases, the respondent may have called a system that serves more than one zone a multizone system, even though the system is not really a multizone system as described above. For example, some of the multizone systems might actually be single-duct VAV systems that serve multiple zones.

The fractions of floor areas served by CAV and VAV system types are difficult to determine, because the fractions for multizone and dual-duct systems are unknown. However, based on data from Modera et al. (1999) and EIA (2002), the fraction of VAV systems may be in the range of 8 to $34 \%$ of the total building floor area. The EIA data indicate that VAV systems serve $34 \%$ of the large commercial building floor area in the U.S. Pacific region, which includes California.

Although there are substantially fewer VAV systems than CAV systems in California, it is clear that VAV systems are used in a significant fraction of California buildings and need to be addressed when developing duct models for large commercial buildings. A reason to focus on VAV systems is that if one is able to model a VAV system, then a CAV system can also be modeled (it is a simplification of a VAV system). Another reason is that an EPRI study (Pietsch 1991) suggested a significant national trend over the past 30 years towards the use of VAV systems in new construction (e.g., about $75 \%$ of new duct systems in the period 1980 through 1990 were VAV systems).

Of the floor area served by single-duct VAV systems, the data from Modera et al. (1999) indicate that most (98\%) of it is in large office buildings; the remainder $(2 \%)$ is primarily in hotel and retail buildings. For this reason, we focused on large office buildings in our study.

\subsection{Effects of Duct Deficiencies}

In large commercial buildings, duct systems and the effects of deficiencies in these systems are much more complex than in most residential and small-commercial buildings. As an example to illustrate the effects of duct system deficiencies, consider a large commercial building equipped with a single-duct terminal-reheat VAV system that has leaky supply ducts located within a ceiling return air plenum.

When conditioned air leaks from the supply ducts, the heating or cooling energy associated with leakage heats or cools the return air and changes its temperature (and enthalpy). Depending on the temperature difference across each surface that separates the plenum from adjacent conditioned spaces and the outdoors, some of the energy associated with the leakage airflow is transferred from the plenum by conduction across these surfaces. The energy transferred by conduction between the plenum and adjacent zones may be beneficial or detrimental to zone loads. For example, when there is simultaneous heating of perimeter zones and cooling of the core zone, the heating energy associated with leakage from ducts that serve the perimeter zones will tend to increase plenum temperatures; the cooling energy associated with leakage from ducts that serve the core zone will tend to decrease plenum temperatures. A net increase in plenum temperatures will increase the core-zone cooling load and decrease the perimeter-zone heating loads. Conversely, a net decrease in plenum temperatures will decrease the core-zone cooling load and increase the perimeter-zone heating loads. 
If the VAV boxes deliberately induce airflows from the ceiling plenum (driven by induction effects or by VAV box fans), the change in return air enthalpy affects the mixed supply air enthalpy within and downstream of the VAV box. This in turn affects the energy that is transferred to the conditioned spaces by these airflows. It can also affect VAV box reheat coil loads (e.g., reduced return air enthalpy due to cool supply air leakage upstream of the VAV box or from other ducts reduces the VAV box mixed air enthalpy and increases reheat coil loads).

A change in return air temperature due to duct leakage will also change cooling coil loads when the economizer is not operating. For example, consider an air-handler with an economizer that is controlled based on dry-bulb temperatures (rather than on enthalpies). When the outdoor air temperature is above the return air temperature high-limit set point, the amount of outdoor air entering the air-handler is the minimum required for ventilation. The remainder of the mixed airflow entering the air-handler (same flow rate as the supply airflow) is return air. Mechanical cooling is used to maintain the desired supply air temperature. In this case, the change in return air enthalpy due to duct leakage will affect the mixed air enthalpy entering the air-handler coils, and therefore will affect the cooling coil loads (e.g., reduced return air enthalpy due to cool supply air leakage reduces mixed air enthalpy and therefore reduces cooling coil loads). To maintain the desired air pressure differentials across the building envelope, some return air is discharged outdoors. This means that some of the heating or cooling energy associated with leakage is discharged to outdoors and is not recaptured at the air-handler.

When the outdoor air temperature is between the desired supply air temperature and return air temperature high-limit set point, the economizer operates with $100 \%$ outdoor air and no return air enters the air-handler (all of the return air is discharged outdoors). In this case, even though mechanical cooling is used as a supplement to maintain the desired supply air temperature, the change in return air enthalpy due to duct leakage does not affect mixed air enthalpy or cooling coil loads. When the outdoor air temperature is below the desired supply air temperature, there is no mechanical cooling and duct leakage again has no impact on air-handler coil loads. However, to maintain the desired supply air temperature in this case, a change in return air temperature (e.g., due to duct leakage) will cause the economizer to alter the amounts of return air and outdoor air that enter the air-handler.

In the case of a VAV box with leaky downstream ducts, the duct leakage means that insufficient heating or cooling energy is delivered to the conditioned spaces. As a result, the thermostat call for heating or cooling is not satisfied and the thermostat calls for more air to be supplied through the VAV box. To deliver more supply air, the VAV box primary air damper opens further, which in turn reduces the resistance to airflow in the duct system. Consequently, to maintain the main duct static pressure at its set point, the supply fan airflow must increase to compensate for the downstream leakage airflows. Upstream leakage has a similar effect on supply fan airflow, but no effect on VAV box flows (unless the supply fan is too small to maintain duct static pressure in the leaky duct system).

Because the relationship between fan power and airflow is somewhere between a quadratic and cubic function (Wray 2003), the increase in supply airflow to compensate for duct leakage means that supply fan power consumption increases significantly, with a large fraction of this fan power used just to move the leaking air. Increasing the fan power also increases cooling coil loads when mechanical cooling is being used to maintain the desired supply air temperature (when the economizer is operating at $100 \%$ or minimum outdoor air). This occurs because the heat created by the increased fan power tends to increase the supply air temperature downstream of the fan. In 
response, the cooling coil water valve open furthers to provide more cooling to maintain the desired supply air temperature.

\section{MODELING APPROACH}

To evaluate the impacts of duct leakage on VAV system performance in large office buildings, we modeled a prototypical office building with different characteristics that represent three building vintages in three California climates with six different duct leakage configurations (54 cases), using DOE-2.1E (Winkelmann et al. 1993a, 1993b) and TRNSYS (Klein et al. 1996). Our modeling approach involves a three-step quasi-steady-state process in which the distribution system simulation is uncoupled from the loads and plant simulations of DOE-2, in the same manner that DOE-2 itself uses. The difference is that the TRNSYS system simulation expands beyond DOE-2 modeling capabilities to offer more flexibility in modeling duct thermal performance. The three steps in our modeling approach are as follows:

1. Hourly zone loads (heat extraction and addition rates) and zone air temperatures are calculated using DOE-2, for a constant air volume (CAV) system that has no duct leakage. These results are then output to a data file, which is read as input by TRNSYS. The data file also includes the corresponding hourly weather conditions, latent heat gains in conditioned spaces, and heat input to the ceiling plenum from lights. DOE-2 simulates all 8760 hours in a year.

2. TRNSYS generates hourly HVAC system fan and coil energy consumption data using interconnected detailed component models for the heating and cooling coils, fans, ducts, terminal boxes, economizer, and return plenum. The solution for each hour involves numerous iterations that terminate when convergence is achieved; convergence occurs when the error tolerances associated with component input and output variables are satisfied. Various duct leakage configurations are modeled at this stage. The TRNSYS analysis considers only hours when the HVAC system is operating. These hours (as defined in Appendix I) are: Monday through Friday, 6 a.m. to 8 p.m., and Saturday, 6 a.m. to 3 p.m.; they exclude Sundays and holidays (system is off on these days).

3. Regression analyses based on correlations that we developed between DOE-2 system and plant energy use are used to translate the TRNSYS system level coil load data to plant level energy use; energy costs are subsequently calculated based on this energy use.

In our evaluation, all but two of the effects described in Section 2.2 were modeled. The VAV box induction flows, as well as the impact on conditioned space loads of plenum temperature changes caused by duct leakage, were not modeled. Modeling these effects requires the use of coupled zone load and HVAC system models, which are not yet available in simulation tools that address duct leakage. Wray (2003) describes our modeling approach in more detail, the duct performance principles on which it is based, and the TRNSYS component models that we used.

An advantage of using the DOE-2/TRNSYS approach in this project is that DOE-2 prototypical models for a large commercial California building are already available, as are the custom TRNSYS component models (Franconi 1999). Another advantage is that the duct leakage modeling approach and its results for a California building have already been validated by Franconi, and no substantial changes to the simulation tool are required to carry out our analyses. No other whole-building modeling approach to assess duct system performance for large commercial buildings is currently as advanced as this approach. 


\section{BUILDING AND HVAC SYSTEM CHARACTERISTICS}

In this study, we modeled a ten story, $150,000 \mathrm{ft}^{2}$ office building. Each story has a floor area of $15,000 \mathrm{ft}^{2}$ and is divided into five zones: four 15 - $\mathrm{ft}$ wide perimeter zones and one core zone. Each set of five zones has a ceiling plenum above them that serves as the return air plenum. The mechanical plant is located in a below-grade basement.

\subsection{Building Envelope}

We modeled three construction eras (1980s, 1990s, and 2005) in three California climates where large commercial buildings are common (Oakland, Pasadena, and Sacramento). The building envelope thermal characteristics are listed in Table 1 for the 1980s and 1990s era buildings and in Table 2 for the 2005 era building. The general characteristics of the 1980s and 1990s era buildings were determined in a previous study (Huang and Franconi 1999). The 2005 era building is based on the requirements of the proposed 2005 California Title 24 Nonresidential Energy Standards (CEC 2003a).

In each case, the intermediate floors are 4 in. thick lightweight $\left(80 \mathrm{lb} / \mathrm{ft}^{3}\right)$ concrete slabs, covered with a carpet and fibrous pad. The basement floor is a 6 in. thick heavyweight concrete slab on top of soil. The exterior walls are $1 \mathrm{in}$. thick stone $\left(140 \mathrm{lb} / \mathrm{ft}^{3}\right), 2$ in. $\mathrm{x} 4$ in. steel studs (16 in. on center), insulation in the wall cavities, and 5/8 in. thick sheet rock. Windows are double-glazed. The bottom of each ceiling return plenum (conditioned space ceiling) is 3/4 in. thick, $2 \mathrm{ft}$. $\mathrm{x} 4 \mathrm{ft}$. acoustic ceiling tiles laid in a steel T-bar frame. The roof assembly above the top story's ceiling return plenum consists of built-up roofing, 4 in. thick lightweight concrete, and insulation. The R-values and U-values that are listed in Tables 1 and 2 are for entire assemblies, not including air films.

Table 1. Building Envelope Characteristics - 1980s and 1990s Construction Based on Huang and Franconi (1999)

\begin{tabular}{|c|c|c|}
\hline & $\begin{array}{c}1980 \mathrm{~s} \\
\text { Construction }\end{array}$ & $\begin{array}{c}1990 \mathrm{~s} \\
\text { Construction }\end{array}$ \\
\hline \multicolumn{3}{|l|}{ Roof } \\
\hline Assembly R-value $\left(\mathrm{h} \cdot{ }^{\circ} \mathrm{F} \cdot \mathrm{ft}^{2} / \mathrm{Btu}\right)$ & 13.1 & 14.5 \\
\hline \multicolumn{3}{|l|}{ Walls } \\
\hline Assembly R-value $\left(\mathrm{h} \cdot{ }^{\circ} \mathrm{F} \cdot \mathrm{ft}^{2} / \mathrm{Btu}\right)$ & 3.1 & 6.6 \\
\hline \multicolumn{3}{|l|}{ Windows } \\
\hline Assembly U-value $\left(\mathrm{Btu} /\left(\mathrm{h} \cdot{ }^{\circ} \mathrm{F} \cdot \mathrm{ft}^{2}\right)\right)$ & 0.72 & 0.60 \\
\hline Relative Solar Heat Gain (RSHG)* & 0.69 & 0.62 \\
\hline Shading Coefficient** & 0.77 & 0.71 \\
\hline Window/Zone-Wall Area Ratio & $40 \%$ & $50 \%$ \\
\hline
\end{tabular}

* RSHG is a function of the solar heat gain coefficient $\left(\mathrm{SHGC}_{\text {win }}\right)$, the window orientation, and the size and position of overhangs. Because the prototypes modeled do not have overhangs, RSHG=SHGC.

** Shading Coefficient $=\mathrm{SHGC} / 0.87=\mathrm{RSHG} / 0.87$. 
Table 2. Building Envelope Characteristics - 2005 Title 24

Based on the Draft 2005 Title 24 Standards (CEC 2003a)

\begin{tabular}{|c|c|c|c|}
\hline & $\begin{array}{l}\text { Oakland } \\
\text { (CZ 3) }\end{array}$ & $\begin{array}{l}\text { Pasadena } \\
\text { (CZ 9) }\end{array}$ & $\begin{array}{c}\text { Sacramento } \\
\text { (CZ 12) }\end{array}$ \\
\hline \multicolumn{4}{|l|}{ Roof } \\
\hline Assembly R-value $\left(\mathrm{h} \cdot{ }^{\circ} \mathrm{F} \cdot \mathrm{ft}^{2} / \mathrm{Btu}\right)$ & 20.9 & 12.9 & 20.9 \\
\hline \multicolumn{4}{|l|}{ Walls } \\
\hline Assembly R-value $\left(\mathrm{h} \cdot{ }^{\circ} \mathrm{F} \cdot \mathrm{ft}^{2} / \mathrm{Btu}\right)$ & 5.4 & 5.4 & 5.7 \\
\hline \multicolumn{4}{|l|}{ Windows } \\
\hline Assembly U-value $\left(\mathrm{Btu} /\left(\mathrm{h} \cdot{ }^{\circ} \mathrm{F} \cdot \mathrm{ft}^{2}\right)\right)$ & 0.77 & 0.77 & 0.47 \\
\hline $\begin{array}{l}\text { Relative Solar Heat Gain (RSHG)* } \\
\text { North } \\
\text { Non-North }\end{array}$ & $\begin{array}{l}0.61 \\
0.41\end{array}$ & $\begin{array}{l}0.61 \\
0.34\end{array}$ & $\begin{array}{l}0.47 \\
0.31\end{array}$ \\
\hline Shading Coefficient (SC)** & & & \\
\hline North & 0.701 & 0.701 & 0.54 \\
\hline Non-North & 0.471 & 0.391 & 0.356 \\
\hline Window/Zone-Wall Area Ratio & $40 \%$ & $40 \%$ & $40 \%$ \\
\hline
\end{tabular}

* The CEC 2005 Title 24 Standards specify a maximum Relative Solar Heat Gain (RSHG) as listed above. RSHG is a function of the solar heat gain coefficient $\left(\mathrm{SHGC}_{\mathrm{win}}\right)$, the window orientation, and the size and position of overhangs. We used the RSHGs specified in the 2005 Title 24 Draft Standards. Because the prototypes modeled do not have overhangs, $\mathrm{RSHG}=\mathrm{SHGC}$.

** Shading Coefficient $=\mathrm{SHGC} / 0.87=\mathrm{RSHG} / 0.87$.

\subsection{Building Operating Characteristics}

Table 3 lists the operating characteristics that we used to model the building prototypes in DOE2. Schedules describing when these characteristics apply are listed in Tables I-1 through I-7 of Appendix I. These schedules are based on the draft 2005 Title 24 schedules (CEC 2003a).

Table 3. Building Operating Characteristics

\begin{tabular}{|l|c|c|c|}
\hline & $1980 \mathrm{~s}^{*}$ & $1990 \mathrm{~s}^{*}$ & $\begin{array}{c}2005 \text { Title } 24 \\
\text { Draft Standard** }\end{array}$ \\
\hline Infiltration (ach) & & & \\
\hline HVAC System Operating & 0 & 0 & 0 \\
\hline HVAC System Off & $0.30^{+}$ & $0.30^{+}$ & $0.075^{* * *}$ \\
\hline Minimum Outside Air (cfm/person) & 15 & 15 & 15 \\
\hline Occupancy $\left(\mathrm{ft}^{2} /\right.$ person) & 100 & 100 & 100 \\
\hline Lighting Intensity (W/ $\left.\mathrm{ft}^{2}\right)$ & 1.8 & 1.3 & 1.1 \\
\hline Equipment Load $\left(\mathrm{W} / \mathrm{ft}^{2}\right)$ & 0.75 & 0.75 & 1.34 \\
\hline
\end{tabular}

* Huang and Franconi (1999), Table 10.

${ }^{+}$Huang (2003).

** CEC (2003a).

*** Based on $0.038 \mathrm{cfm} / \mathrm{ft}^{2}$ of exterior wall area, as proposed in the 2005 Title 24 Draft (CEC 2003a).

Infiltration is assumed to be zero when the HVAC system is operating. When the HVAC system is off, the infiltration rate is assumed to be the air change rate listed in Table 3, as appropriate for each case. The "off hours" infiltration rate for the 1980s and 1990s era buildings ( 0.3 ach, Huang 
2003 ) is about midway in the range reported by Grot and Persily (1986) for eight 1980s era office buildings that they tested $(0.1$ to $0.6 \mathrm{ach})$. The hourly outdoor airflow rates modeled during system operating hours are based on the hourly occupancy schedules and the outdoor airflow rate requirements per person specified in the draft 2005 Title 24 standard (CEC 2003a).

Of the heat generated by the light fixtures, $45 \%$ is transferred to the occupied zones; the remainder goes to the ceiling return plenum (Huang 2003).

\subsection{Air-Handling System Description}

The single-duct VAV terminal-reheat air distribution system that we modeled in TRNSYS includes an airside economizer, a cooling coil, a variable-speed supply fan, five pressureindependent VAV-boxes (each with a discharge reheat coil), a ceiling return air plenum, and a variable-speed return fan. The system serves the five building zones on a single floor: four perimeter zones and one core zone. It is assumed that identical systems serve each of the ten floors in the building.

The system economizer uses the following control strategy:

- When the outdoor air temperature is above the return air temperature high-limit set point $\left(70^{\circ} \mathrm{F}\right.$ in Sacramento, and $75^{\circ} \mathrm{F}$ in Oakland and Pasadena, CEC 2003a), the amount of outdoor air entering the air-handler is the minimum required for ventilation. The remainder of the mixed airflow entering the air-handler (same flow rate as the supply airflow) is return air. Mechanical cooling is used to maintain the desired supply air temperature. To maintain a zero air pressure differential across the building envelope, the amount of return air discharged to outdoors is the same as the amount of outdoor air entering the air-handler.

- When the outdoor air temperature is between the desired supply air temperature and return air temperature high-limit set point, the economizer operates with $100 \%$ outdoor air and no return air enters the air-handler (all of the return air is discharged outdoors). Mechanical cooling is used as a supplement to maintain the desired supply air temperature.

- When the outdoor air temperature is below the desired supply air temperature, there is no mechanical cooling. In this case, the economizer mixes appropriate amounts of return air and outdoor air to maintain the desired supply air temperature.

In all cases, the minimum outdoor air ventilation rate is set to correspond to a minimum outdoor airflow of 2,250 cfm per floor at design conditions. This value is based on the occupant density of $100 \mathrm{ft}^{2} /$ person and the outdoor-air ventilation rate of $15 \mathrm{cfm} /$ person described in Table 3 . For each case, the minimum outdoor air ventilation rate is a constant fraction of the supply fan airflow, but this fraction is not necessarily constant from case to case because design supply airflows vary from case to case.

The cooling coil control is simple: a constant supply air dry-bulb temperature of $53^{\circ} \mathrm{F}$ is maintained downstream of the supply fan. This temperature was selected to achieve a $20^{\circ} \mathrm{F}$ supply air temperature difference relative to the $73^{\circ} \mathrm{F}$ cooling set-point temperature of the conditioned spaces.

All VAV boxes have the same flow fraction at their minimum turndown. For each box, this fraction is set at $40 \%$ of the design maximum flow rate entering the box to ensure that sufficient 
heat can be delivered to the zone, assuming a $180^{\circ} \mathrm{F}$ water temperature entering the reheat coils. In some cases, lower turndown fractions (e.g., 30\%) could have been used to satisfy heating requirements; however, for consistency, we used the same turndown fraction in all cases.

\subsection{Cooling and Heating Plant Description}

A water-cooled hermetic centrifugal chiller supplies chilled water to the air-handling system cooling coil. The chiller rejects heat outdoors using a cooling tower. A natural-gas-fired boiler supplies hot water to the VAV box reheat coils. We used the default DOE-2 plant equipment models for the chiller, cooling tower, boiler, and associated circulation pumps.

The heat gain associated with the boiler standby loss to the unconditioned basement $(\mathrm{Btu} / \mathrm{h})$ is calculated as 0.0057 times the boiler fuel efficiency ( $80 \%$ for the 2005 vintage, $79 \%$ for the others) times the total building occupied floor area (Franconi 1999). Combustion air to the basement for the boiler is assumed to be two air changes per hour (Huang 2003).

\subsection{Duct Leakage Characteristics}

\section{Upstream Leakage}

The supply and return fans in the VAV system have variable-speed-drive control. Although not modeled explicitly, we assume that the HVAC control system varies the supply fan airflow to maintain a constant duct static pressure upstream of the VAV boxes. In a VAV distribution system with constant static-pressure control, the pressure distribution along the ducts upstream of the VAV zone boxes is affected by several parameters, which include: the duct friction and fitting pressure drops, the system equipment (e.g., mixing dampers, cooling coil, air filters) pressure drops, the static-pressure set point, and the placement of the static-pressure sensor. The duct and system equipment pressure drops vary with airflow. Therefore, in general, the pressure differences across the upstream leaks when the fan operates at design conditions (maximum fan airflow) will differ from the pressure differences across the leaks during part-load fan operation (reduced fan airflow). In certain circumstances, upstream leakage airflow is not affected by partload fan operation and the average upstream duct air leakage is constant. This is only precisely true when all of the duct leaks are located at the same location as the pressure sensor, and pressure reset control is not in use.

The simplifying assumption that we used for modeling leakage upstream of the VAV boxes is that the upstream leakage airflow is constant and is not affected by the airflow through the fan. This implies that the fraction of the fan airflow that is leaking upstream of the VAV boxes increases as the fan airflow is reduced.

\section{Downstream Leakage}

Downstream of a VAV box, the duct pressure distribution is affected by the box damper position, which provides a variable flow resistance to control the downstream duct airflow. The pressure differences across the leaks in the downstream ducts can be related to the average pressure drop through these ducts. If turbulent flow through the duct is assumed, the airflow rate affects the duct pressure drop according to the square law. If it is also assumed that there is a square root relationship between leakage flow and pressure difference across the duct leaks, then the fraction of the VAV box airflow that leaks from the ducts downstream of the boxes remains approximately constant. However, the leakage airflow is not constant. 


\section{Nominal Leakage Fraction}

Based on the simplifying assumptions described above, two inputs are required to describe supply duct leakage in the TRNSYS simulation: upstream leakage fraction and downstream leakage fraction. The upstream leakage fraction is the upstream leakage flow, which is a constant for all part load ratios, divided by the supply fan design airflow. The downstream leakage fraction is a constant fraction of the VAV box airflow, which varies during system operation.

In the TRNSYS simulations, we used six leakage configurations in each of the three climates for each of the three building vintages ( 54 cases) to evaluate the variability of duct leakage impacts on HVAC system energy performance:

- $10+10$, which refers to a $10 \%$ leakage fraction upstream of the VAV boxes and a $10 \%$ leakage fraction downstream of the VAV boxes (about 19\% total leakage) at design flow;

- $7.5+7.5$, which refers to $7.5 \%$ leakage fractions upstream and downstream (about 14\% total leakage) at design flow;

- $10+2.5$, which refers to a $10 \%$ leakage fraction upstream and a $2.5 \%$ leakage fraction downstream (about 12\% total leakage) at design flow;

- $\quad 2.5+10$, which refers to a $2.5 \%$ leakage fraction upstream and a $10 \%$ leakage fraction downstream (also about 12\% total leakage) at design flow;

- $5+5$, which refers to $5 \%$ leakage fractions upstream and downstream (about $10 \%$ total leakage) at design flow; and

- $2.5+2.5$, which refers to $2.5 \%$ leakage fractions upstream and downstream (about 5\% total leakage) at design flow.

The last case represents a tight duct system, but not a perfect one with zero leakage. It is unlikely that real duct systems can be made perfectly tight.

Note that the sum of the upstream and downstream leakage fractions at design flow do not equal the total leakage fraction. This is because the upstream leakage is a fraction of the supply fan flow and the downstream leakage is a fraction of the flow entering the VAV boxes. For example, in the $10+10$ case, if the supply fan flow is $10,000 \mathrm{cfm}$, then the upstream leakage is $1,000 \mathrm{cfm}$ $(10 \%$ of $10,000 \mathrm{cfm})$ and $9,000 \mathrm{cfm}$ reaches the VAV boxes. The downstream leakage is therefore $900 \mathrm{cfm}(10 \%$ of $900 \mathrm{cfm})$ and $8,100 \mathrm{cfm}$ reaches the zones. This means that a total of $1,900 \mathrm{cfm}$ or $19 \%$ of the $10,000 \mathrm{cfm}$ supply fan flow has leaked from the ducts.

\subsection{Plenum Energy Balance}

In our TRNSYS model of the ceiling return air plenum, the zone return air passes through an open ceiling plenum and then to the return air ducts and fan. An energy balance is used to determine the return plenum air temperature. This energy balance accounts for the effects of supply-duct air leakage, plenum "floor" (zone ceiling) and "ceiling" (zone floor) conduction, plenum exterior wall conduction, heat gain from ceiling-mounted lights, and zone return airflow.

Our simulations show that the plenum is slightly cooler when there is duct leakage. For each hour in the leakiest case (19\% total duct leakage), the plenum temperature is 1 to $2^{\circ} \mathrm{F}$ cooler than the corresponding temperature in the "tight" (5\% total duct leakage) case. The largest plenum temperature reduction occurs when the cooling effect due to supply air leakage is largest, which is also when the largest net cooling load in the conditioned zones occurs. These plenum 
temperature changes are consistent with our field observations in an office building when 15\% leakage was added to a VAV system with 5\% leakage (Diamond et al. 2003).

Although we included the effects of plenum "floor" and "ceiling" conduction in calculating the return plenum air temperature, our uncoupled sequential approach to evaluate the zone loads and HVAC system performance ignores the impact of the plenum temperature changes due to leakage on heating or cooling loads and air temperatures in the conditioned zones. We ignored this effect because it is small compared to the impacts of other gains and losses in the conditioned spaces (e.g., solar loads; occupancy, equipment, and lighting heat gains; exterior wall and window conduction). For example, the largest plenum temperature reduction $\left(2^{\circ} \mathrm{F}\right)$ due to $19 \%$ total leakage, which corresponds with the largest net cooling load in the conditioned zones, would only reduce the cooling load by about 3\%. A more rigorous approach to account for this effect would involve a coupled simultaneous solution of the loads, system, and plant performance. In the future, EnergyPlus could be used for this purpose if the TRNSYS duct models were integrated with that program.

\subsection{Fan Performance}

In many hourly simulation programs, including DOE-2, the fan performance subroutines are based on a third-order polynomial relating the fan fractional shaft power to the fan part load airflow ratio (Brandemuehl et al. 1993). The form of the equation is:

$$
F P R=c_{0}+c_{1} \cdot P L R+c_{2} \cdot P L R^{2}+c_{3} \cdot P L R^{3}
$$

where

FPR: $\quad$ Fan power ratio, which is the dimensionless ratio of the fan shaft power at a particular time to the fan shaft power under design conditions;

PLR: $\quad$ Part load ratio, which is the dimensionless ratio of the fan airflow at the same time to the fan airflow under design conditions; and

$c_{0} \ldots c_{3}:$ Constant coefficients for the curve fit. The specific coefficients depend on the pressure drop, pressure control, and airflow characteristics of the system.

Table 4 defines the coefficients for various fan control schemes. These include: outlet damper control, inlet vane control, and variable speed control. There are two sets of coefficients listed for variable speed control. One is a set of coefficients used in DOE-2 and in the ASHRAE HVAC Toolkit for a generic fan, and produces a curve similar to the one used by Franconi (1999) for part load airflow fractions of one or less. The other set corresponds to the relation defined in the Title 24 Nonresidential Alternative Calculation Method (ACM) (CEC 2003b) for a variable speed drive with static pressure control. We used the Title 24 set of coefficients in our simulations.

Table 4. Polynomial Coefficients for Fan Performance Curves

\begin{tabular}{c|c|c|c|c}
\hline Fan Control Type & $\mathrm{c} 0$ & $\mathrm{c} 1$ & $\mathrm{c} 2$ & $\mathrm{c} 3$ \\
\hline Outlet Damper & 0.3507 & 0.3085 & -0.5414 & 0.8720 \\
Inlet Vane & 0.3707 & 0.9725 & -0.3424 & 0 \\
Variable Speed Drive (Generic) & 0.0015 & 0.00521 & 1.1086 & -0.1164 \\
Variable Speed Drive (Title 24) & 0.1021 & -0.1177 & 0.2647 & 0.7600 \\
\hline
\end{tabular}


Figure 1 shows the differences between the relationships. For fan part load airflow fractions greater than about 0.33 , the Title 24 curve results in the lowest fan power. In our simulations, fan part load flow fractions were typically concentrated in a range of 0.4 to 0.8 .

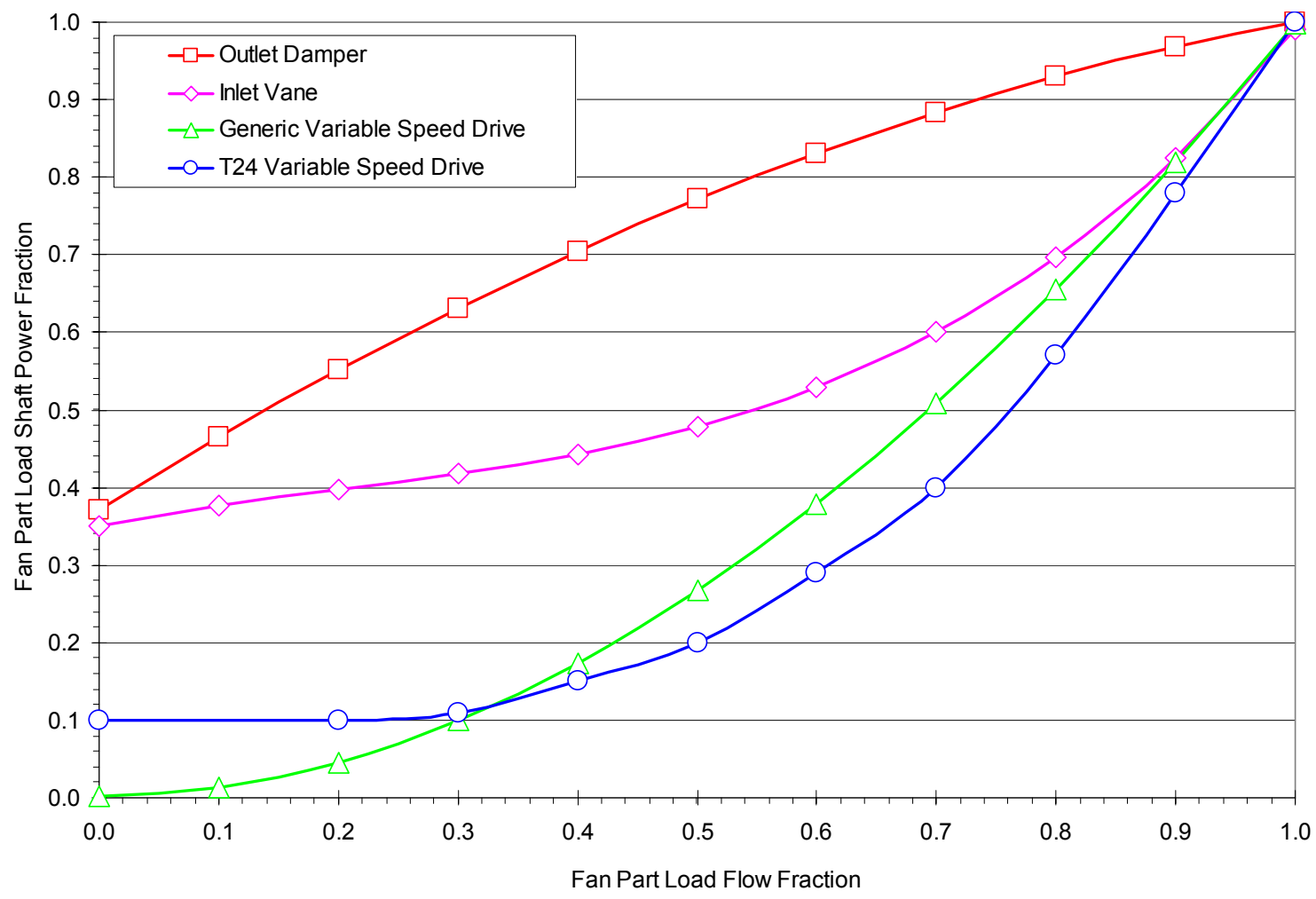

Figure 1. Comparison of Fan Performance Curves

\subsection{System and Plant Sizing}

The VAV system that we simulated in TRNSYS used the same size system and plant equipment for the various duct leakage cases in a given climate and for a given building vintage; however, the sizes varied over the nine building vintage and climate combinations.

The supply (and return) fan design airflow was determined by the high-leakage case $(10+10)$, because the maximum airflow occurs for that case. The intermediate-floor supply fan design airflows for each climate and building vintage combination are listed in Table 5, and are based on the calculated zone airflow requirements with leakage effects added. Supply and return fan power at design conditions are based on the design airflow, total pressure rises of 3 in. of water for the supply fan and $1 \mathrm{in}$. of water for the return fan, a combined fan and drive efficiency of $65 \%$ for each fan, and motor efficiencies of $90 \%$ for the supply fan and $88 \%$ for the return fan. Based on these fan parameters, the specific total fan electrical power is $0.8 \mathrm{~W} / \mathrm{cfm}$. These parameters represent a low-pressure system that serves a single floor. Systems with larger pressure rises will use more fan power, which will make duct sealing even more cost-effective. 
Table 5. TRNSYS Air-Handler Fan Design Parameters (Airflows and Electrical Power for Intermediate Floor)

\begin{tabular}{|c|c|c|c|c|c|}
\hline Climate Zone & Vintage & $\begin{array}{c}\text { Supply Fan } \\
\text { Airflow } \\
(\mathrm{cfm})\end{array}$ & $\begin{array}{c}\text { Supply Fan } \\
\text { Power } \\
(\mathrm{kW})\end{array}$ & $\begin{array}{c}\text { Return Fan } \\
\text { Power } \\
(\mathrm{kW})\end{array}$ & $\begin{array}{c}\text { Total Fan } \\
\text { Power } \\
(\mathrm{kW})\end{array}$ \\
\hline CZ3 & $1980 \mathrm{~s}$ & 13,000 & 7.8 & 2.8 & 10.6 \\
(Oakland) & $1990 \mathrm{~s}$ & 13,000 & 7.8 & 2.8 & 10.6 \\
& 2005 & 10,500 & 6.3 & 2.2 & 8.5 \\
\hline CZ9 & $1980 \mathrm{~s}$ & 21,100 & 12.7 & 4.5 & 17.2 \\
(Pasadena) & $1990 \mathrm{~s}$ & $23,700^{*}$ & 14.3 & 5.0 & 19.3 \\
& 2005 & 15,200 & 9.1 & 3.2 & 12.3 \\
\hline CZ12 & $1980 \mathrm{~s}$ & 16,800 & 10.1 & 3.6 & 13.7 \\
(Sacramento) & $1990 \mathrm{~s}$ & 16,300 & 9.8 & 3.5 & 13.3 \\
& 2005 & 12,100 & 7.3 & 2.6 & 9.9 \\
\hline
\end{tabular}

* Increased wall insulation and window solar heat gain in the 1990s changed the time (and therefore outdoor conditions) when peak loads occur in the Pasadena building. This resulted in increased indoor temperatures when the air-handling system is off, which in turn resulted in larger cooling loads at the start of the occupied (conditioned) periods.

The chilled-water coil and VAV-box reheat coils are also sized sufficiently to meet the maximum coil loads ( $20 \%$ oversizing). For sizing the cooling coils, we assumed a $12^{\circ} \mathrm{F}$ waterside temperature rise and an entering water temperature of $44^{\circ} \mathrm{F}$; for the reheat coils, we assumed the water-side temperature drop was $30^{\circ} \mathrm{F}$ and the entering water temperature was $180^{\circ} \mathrm{F}$.

Table 6 summarizes the cooling and heating coil sizes per floor that were generated by DOE-2 (for a CAV system), and which DOE-2 used to size the plant equipment for its plant energy use simulations (with no duct leakage). Table 6 also lists the corresponding coil sizes that we calculated and that were used in the TRNSYS VAV system simulations. The TRNSYS coil sizes differ from the DOE-2 sizes for three reasons:

1. The TRNSYS cooling and heating coil sizes account for the effects of duct leakage on coil loads.

2. The TRNSYS reheat coil sizes are for a VAV system rather than a CAV system, and VAV system reheat loads are smaller because supply airflows are lower during reheat for a VAV system.

3. The TRNSYS sizes are based on the zone loads and corresponding zone temperatures generated by DOE-2, but are determined using VAV system-sizing calculations independent of DOE-2. The calculations that we used are based on methods outlined by Knebel (1983), Kreider and Rabl (1994), and Pedersen et al. (1998). 
Table 6. Cooling and Heating Coil Sizes (kBtu/(h•floor))

\begin{tabular}{|c|c|c|c|c|c|}
\hline & & \multicolumn{2}{|c|}{ DOE-2 } & \multicolumn{2}{c|}{ TRNSYS } \\
\hline Climate Zone & Vintage & Cooling & Heating & Cooling & Heating \\
\hline CZ3 & $1980 \mathrm{~s}$ & 315 & 354 & 470 & 262 \\
(Oakland) & $1990 \mathrm{~s}$ & 308 & 331 & 458 & 236 \\
& 2005 & 252 & 271 & 407 & 202 \\
\hline CZ9 & $1980 \mathrm{~s}$ & 428 & 277 & 528 & 177 \\
(Pasadena) & $1990 \mathrm{~s}$ & 419 & 270 & 544 & 185 \\
& 2005 & 353 & 198 & 483 & 129 \\
\hline CZ12 & $1980 \mathrm{~s}$ & 450 & 438 & 598 & 337 \\
(Sacramento) & $1990 \mathrm{~s}$ & 434 & 397 & 576 & 294 \\
& 2005 & 339 & 249 & 483 & 180 \\
\hline
\end{tabular}

\section{SYSTEM - PLANT ENERGY USE REGRESSIONS}

As described in Appendix II, we determined that the whole-building heating and cooling plant hourly demands and annual energy consumption (electricity and natural gas) can be predicted based on the heating and cooling coil loads of a mid-height intermediate floor. In this analysis, we calculated hourly heating and cooling part load factors for the intermediate floor and for the whole building. For the intermediate floor, the five reheat coil loads were summed for each hour to obtain an hourly total heating coil load for that floor. The hourly total heating coil loads for the floor were then divided by the maximum of those values to obtain the intermediate-floor hourly heating part load ratios. We used the hourly total cooling coil loads for the same floor in a similar manner to determine the intermediate-floor hourly cooling part load ratios. Also, we used the whole-building hourly heating and cooling total coil loads in the same manner to obtain the whole-building heating and cooling part load ratios.

We used regression techniques to generate polynomial relationships between the intermediatefloor hourly part load ratios and the hourly whole-building plant energy demand (chiller electricity, cooling tower electricity, and boiler electricity and natural gas). Tables II-3a though II- $6 c$ in Appendix II provide the regression equations, equation coefficients, regression $\mathrm{R}^{2}$ values, and example predicted values. The $\mathrm{R}^{2} \mathrm{~s}$ for the regression equations for all three vintages and climate zones ranged from 0.9999 to 1.000 for the chiller electricity demand, 0.9338 to 0.9997 for the cooling tower electricity demand, 0.9990 to 1.0000 for the boiler electricity demand, and 0.9984 to 0.9997 for the boiler natural gas demand. The resulting equations were applied to the TRNSYS coil loads to predict whole building plant electricity and natural gas consumption for each of the various leakage cases modeled.

Figures 2 through 7 provide example regression plots to illustrate the relationships between the various parameters for the 2005 Title 24 compliant building in Sacramento (CEC Climate Zone 12). These plots are representative of the plots for other climate zones and building vintages. In particular, Figures 2 and 3 compare the whole-building part load ratios and the intermediate-floor part load ratios. Figures 4 through 7 show, for the same building prototype and climate, the chiller, cooling tower, and boiler electricity demand curves, and the boiler natural gas demand curve, all based on the intermediate-floor part load ratios. Compared to the other plant demand 
data, the cooling tower electricity data has more scatter. However, the annual cooling tower electricity consumption predicted using the regression equation was less than $1 \%$ different from the annual sum of the cooling tower electricity consumption reported by DOE- 2 .

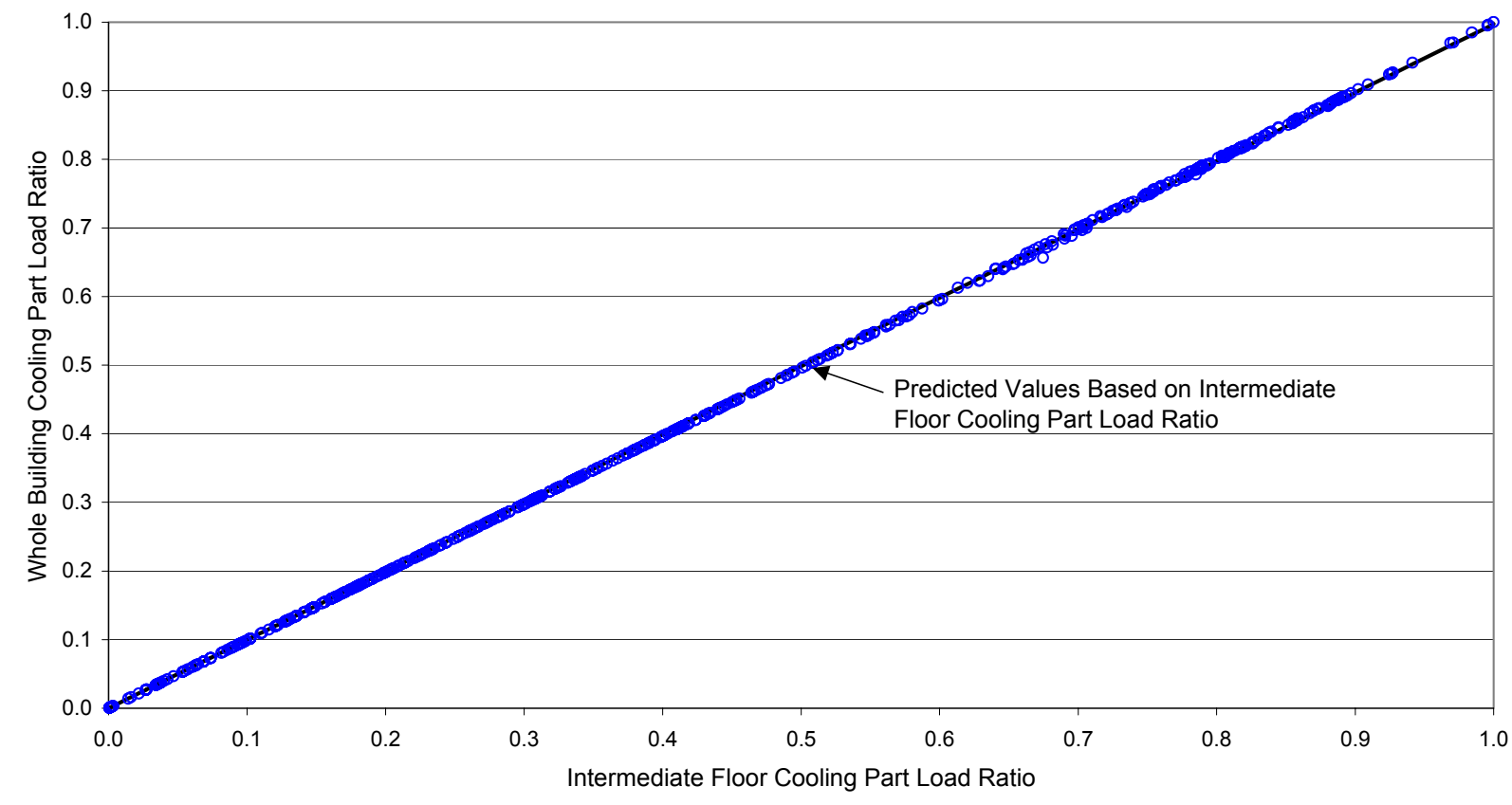

Figure 2. Building Cooling Part Load Ratio Regression CZ 12 (Sacramento) - 2005 Title 24 Compliant Large Office Building

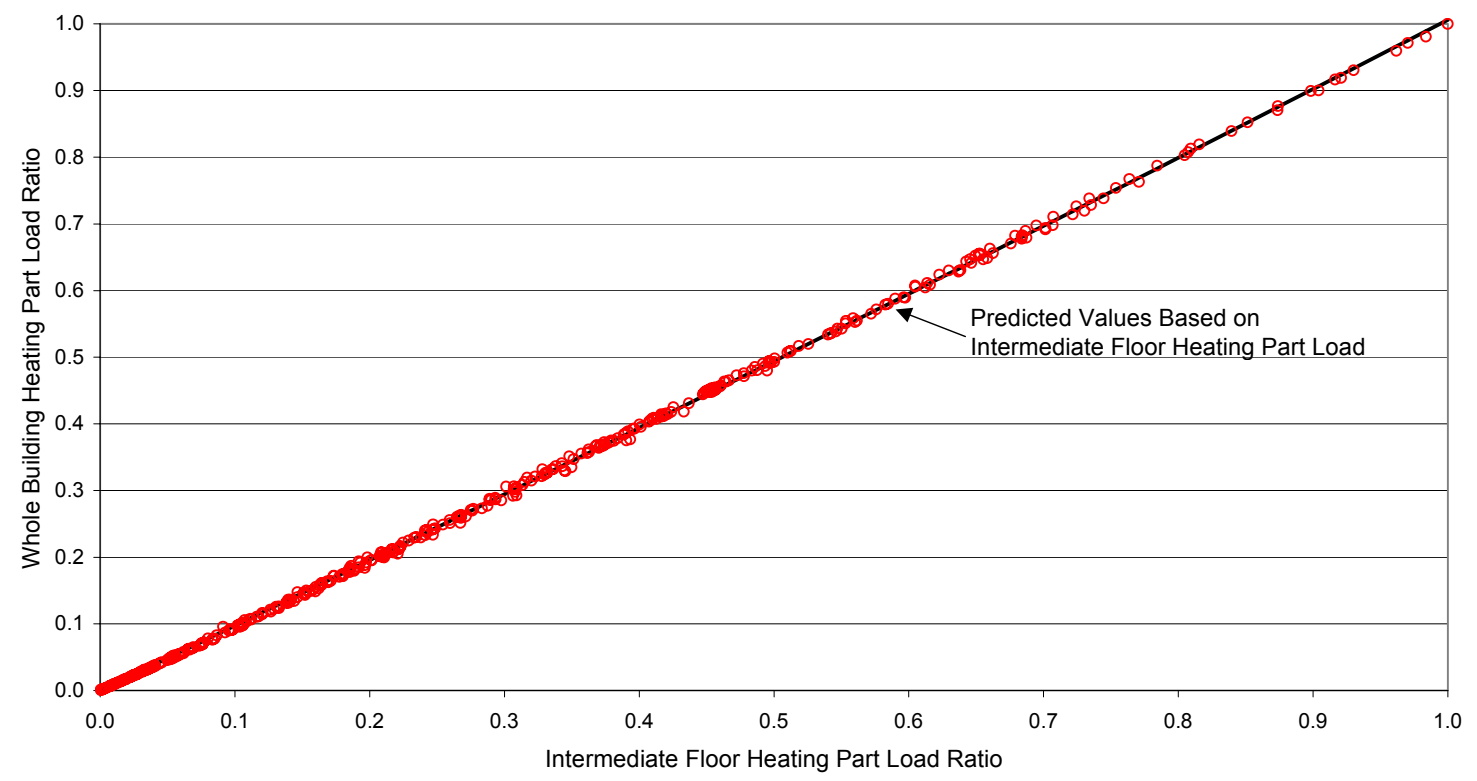

Figure 3. Building Heating Part Load Ratio Regression CZ 12 (Sacramento) - 2005 Title 24 Compliant Large Office Building 


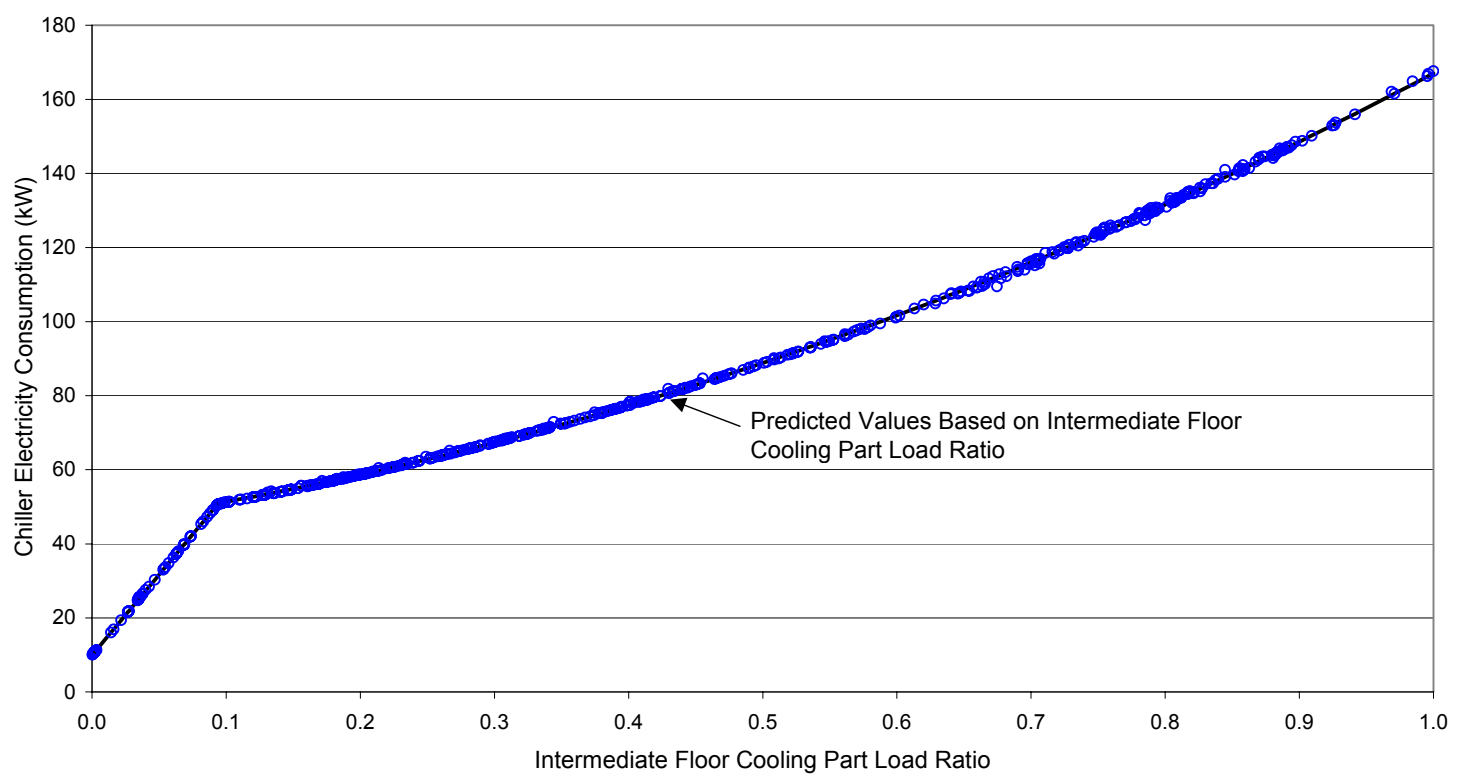

Figure 4. Chiller Electricity Consumption (kW) CZ 12 (Sacramento) - 2005 Title 24 Compliant Large Office Building

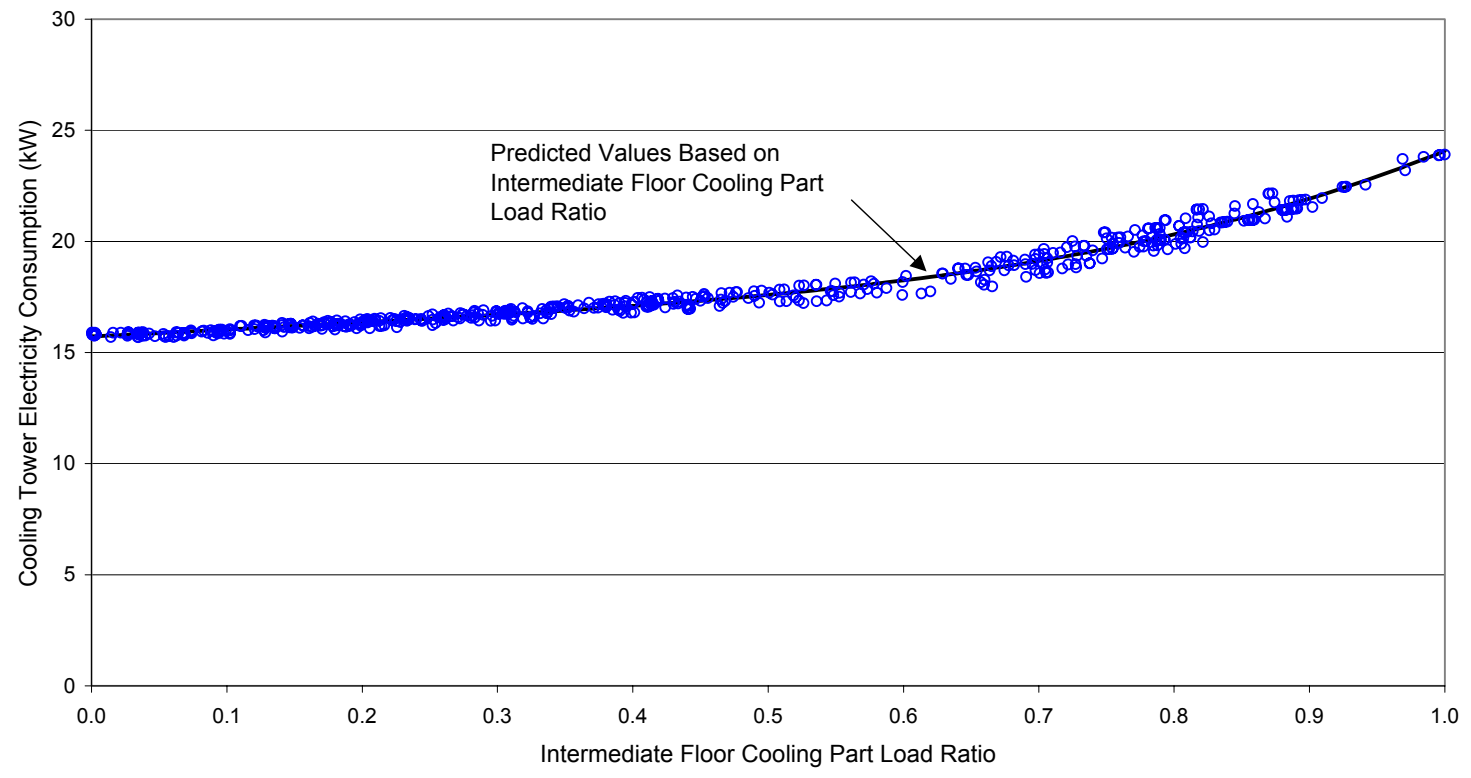

Figure 5. Cooling Tower Electricity Consumption $(\mathrm{kW})$

CZ 12 (Sacramento) - 2005 Title 24 Compliant Large Office Building 


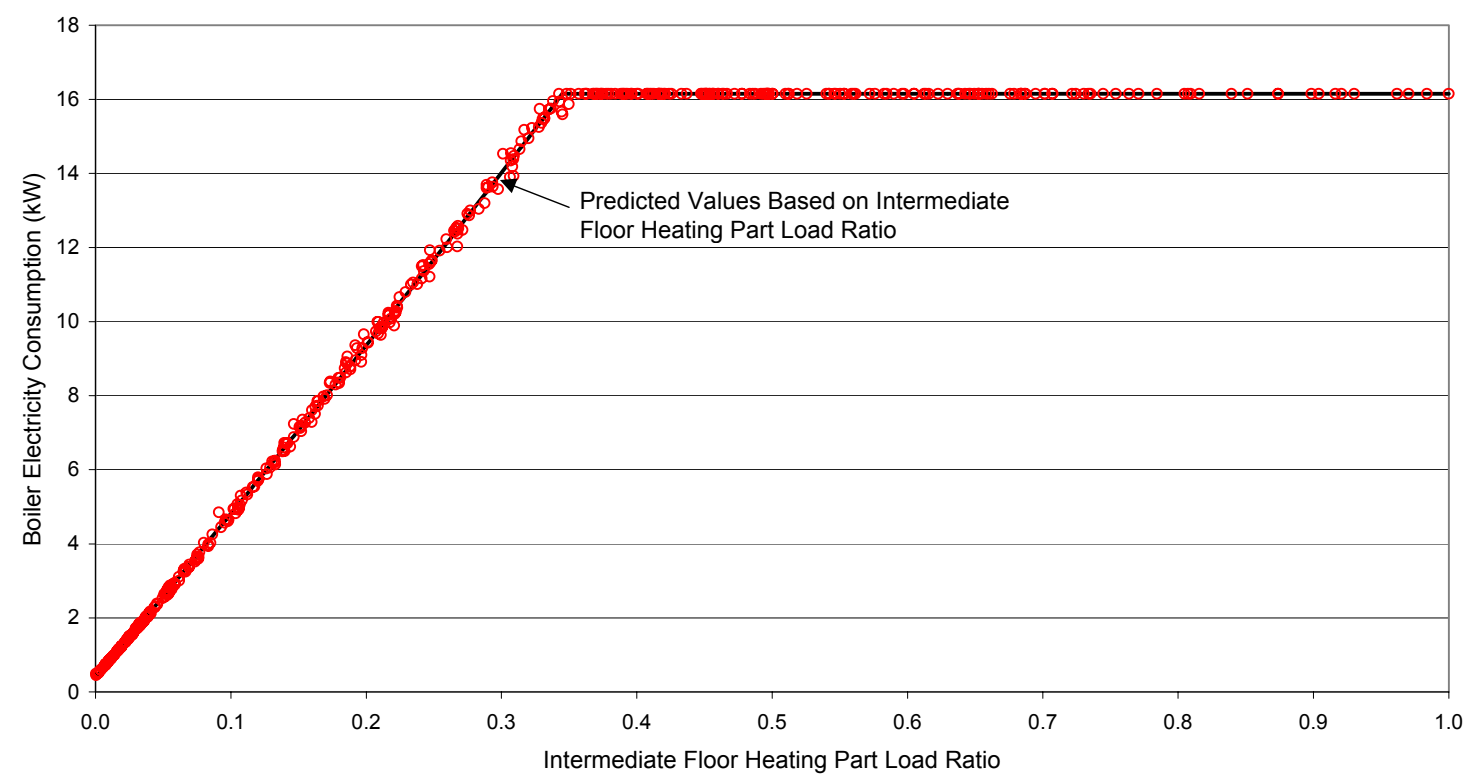

Figure 6. Boiler Electricity Consumption Regression (kW) CZ 12 (Sacramento) - 2005 Title 24 Compliant Large Office Building

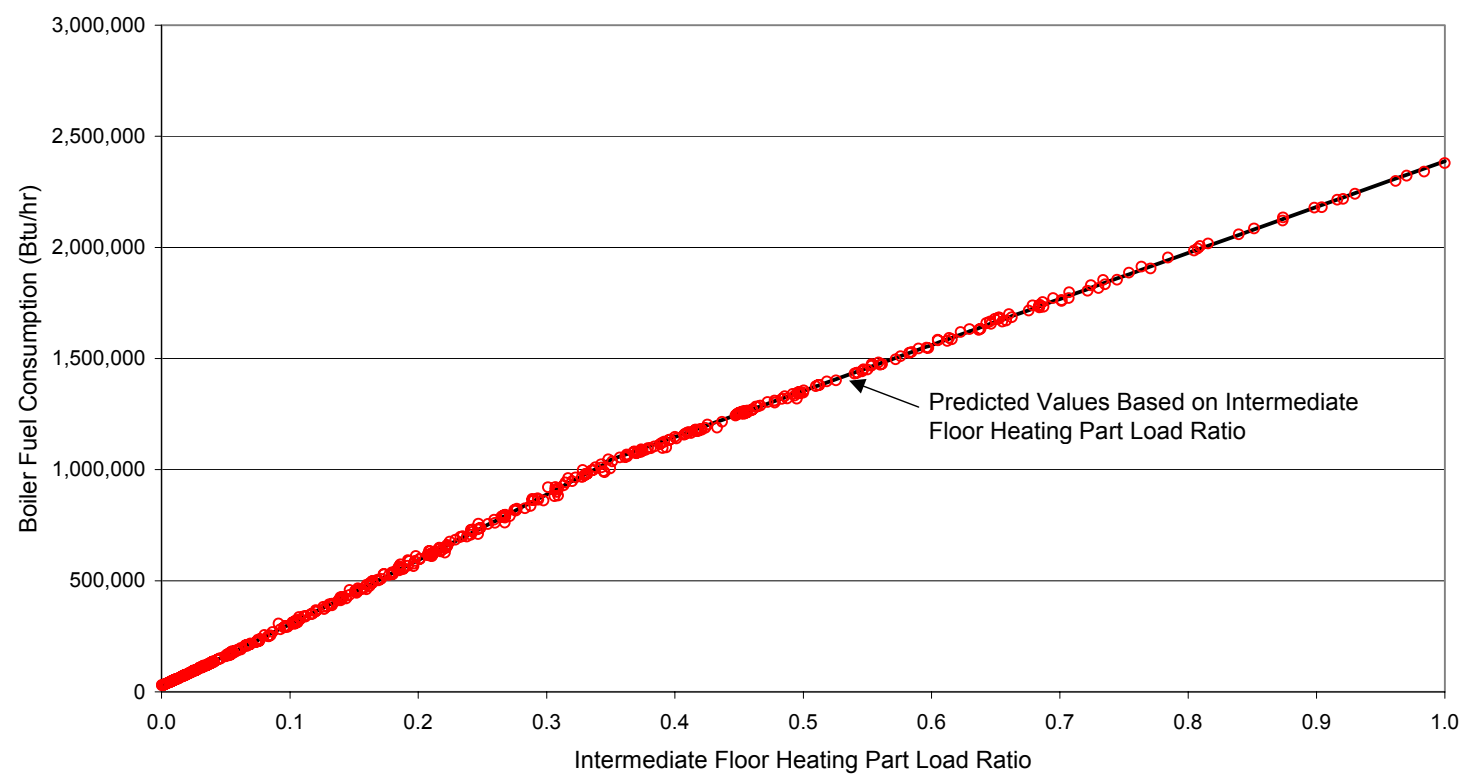

Figure 7. Boiler Fuel Consumption Regression (Btu/h) CZ 12 (Sacramento) - 2005 Title 24 Compliant Large Office Building 


\section{RESULTS}

The sequential DOE-2/TRNSYS modeling approach could best be described as "user hostile". It is unlikely this approach would be practical on a day-to-day basis for Title 24 compliance analyses or even ever used outside a research environment. To reduce the difficulty of using this approach, the authors have developed a spreadsheet-based "graphical interface" (not generated by TRNSYS itself) that organizes and displays various key input and output parameters of TRNSYS. This graphical aid greatly facilitates understanding the complex interactions between system flows, loads, and temperatures.

Figures 8 and 9 show two samples of the performance parameters calculated by TRNSYS for two different hours of VAV system operation in the 2005 Title 24 Sacramento building. Both cases represent a system with $10 \%$ duct leakage upstream and $10 \%$ duct leakage downstream of the VAV boxes at design conditions. Dashed lines leading from the ducts to the ceiling plenum show leakage paths.

Figure 8 shows the system performing on a cool January day under heating conditions, with the VAV boxes operating at or near their minimum flows, and with reheat being added to the supply air for all five zones. In this case, the economizer is partly open to mix outdoor air with return air and maintain the desired supply air temperature downstream of the supply fan, so that no heat needs to be extracted by mechanical cooling through the cooling coil. A supply air temperature reset strategy would reduce the reheat coil loads in this case, but our TRNSYS models for a VAV system do not include this capability.

In Figure 9, the system is performing with a large cooling load in every zone at the start of a warm July day. All VAV boxes are open part way to supply sufficient cool air to meet the zone loads. There is no reheat in this case. The economizer is open completely to reduce the mechanical cooling through the cooling coil. All return air is exhausted to outdoors.

\subsection{Air-Handler Fan Power Ratios}

The largest effect that duct leakage has on distribution system performance is to increase fan energy consumption. Using the DOE-2/TRNSYS simulation approach, we explored the impacts of upstream and downstream leakage independently and in combination.

Figures 10 through 14 show the hourly supply and return fan power ratios versus the fraction of design airflow delivered to the zones for the 2005 Title 24 Sacramento building. The fan power ratio is the hourly fan power for the leaky duct case relative to the fan power in the same hour for the tight duct system (about 5\% total leakage). Five cases are shown: $2.5 \%$ upstream leakage plus $10 \%$ downstream leakage, $10 \%$ upstream leakage plus $2.5 \%$ downstream leakage, $10 \%$ upstream leakage plus 10\% downstream leakage, 7.5\% upstream leakage plus 7.5\% downstream leakage, and 5\% upstream leakage plus 5\% downstream leakage. The upstream leakage is a fixed mass flow (specified fraction of supply fan design flow rate); the downstream leakage is a fixed fraction of VAV box flow, even under part-load conditions. The air mass flow through the return fan matches the air mass flow through the supply fan (return fan and supply fan volumetric flows differ due to air temperature differences between the two airstreams).

Plots for other climates and building vintage combinations are not shown, but are similar to the five included here. 


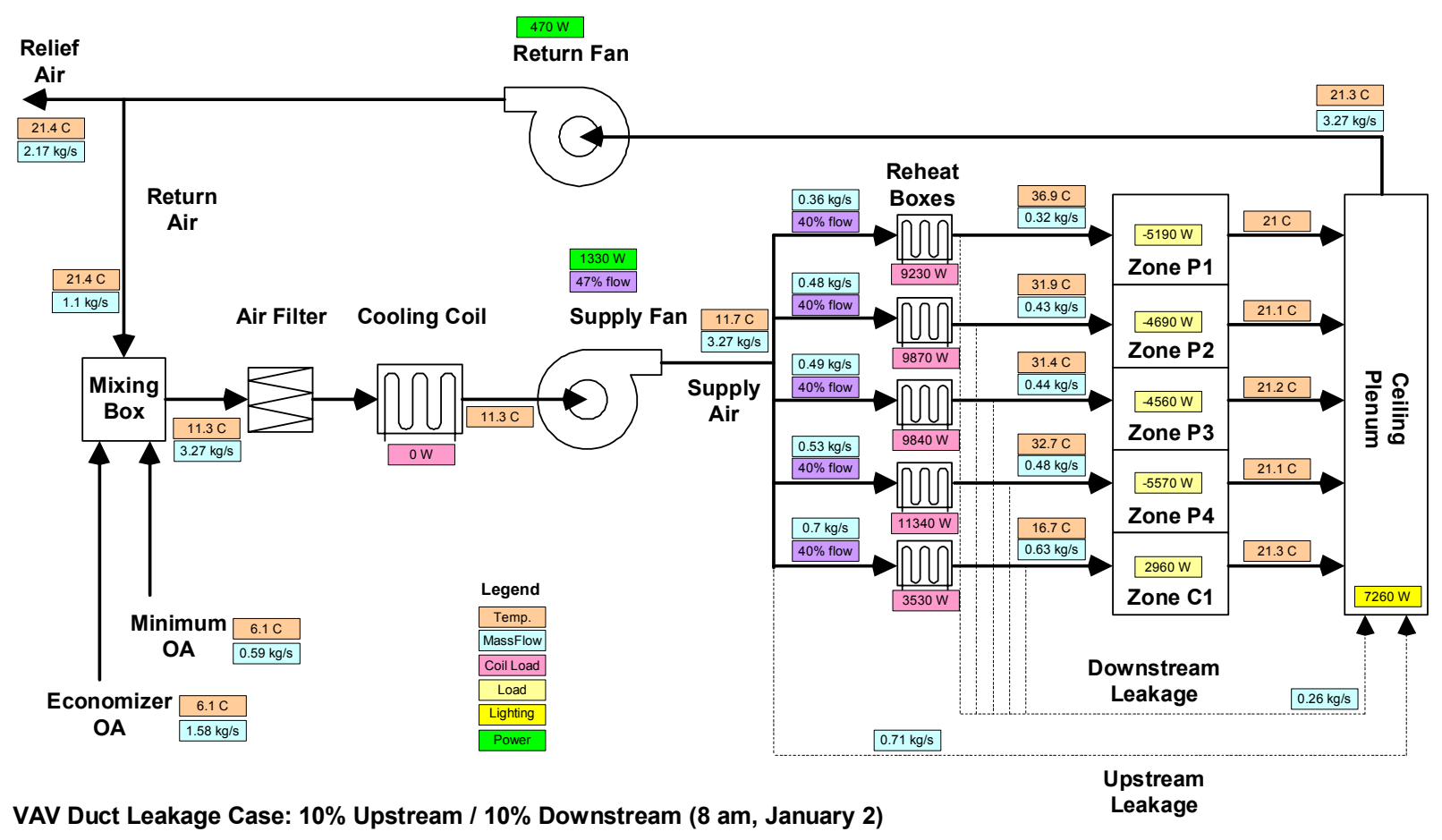

Figure 8. Sample TRNSYS Output - Heating Hour

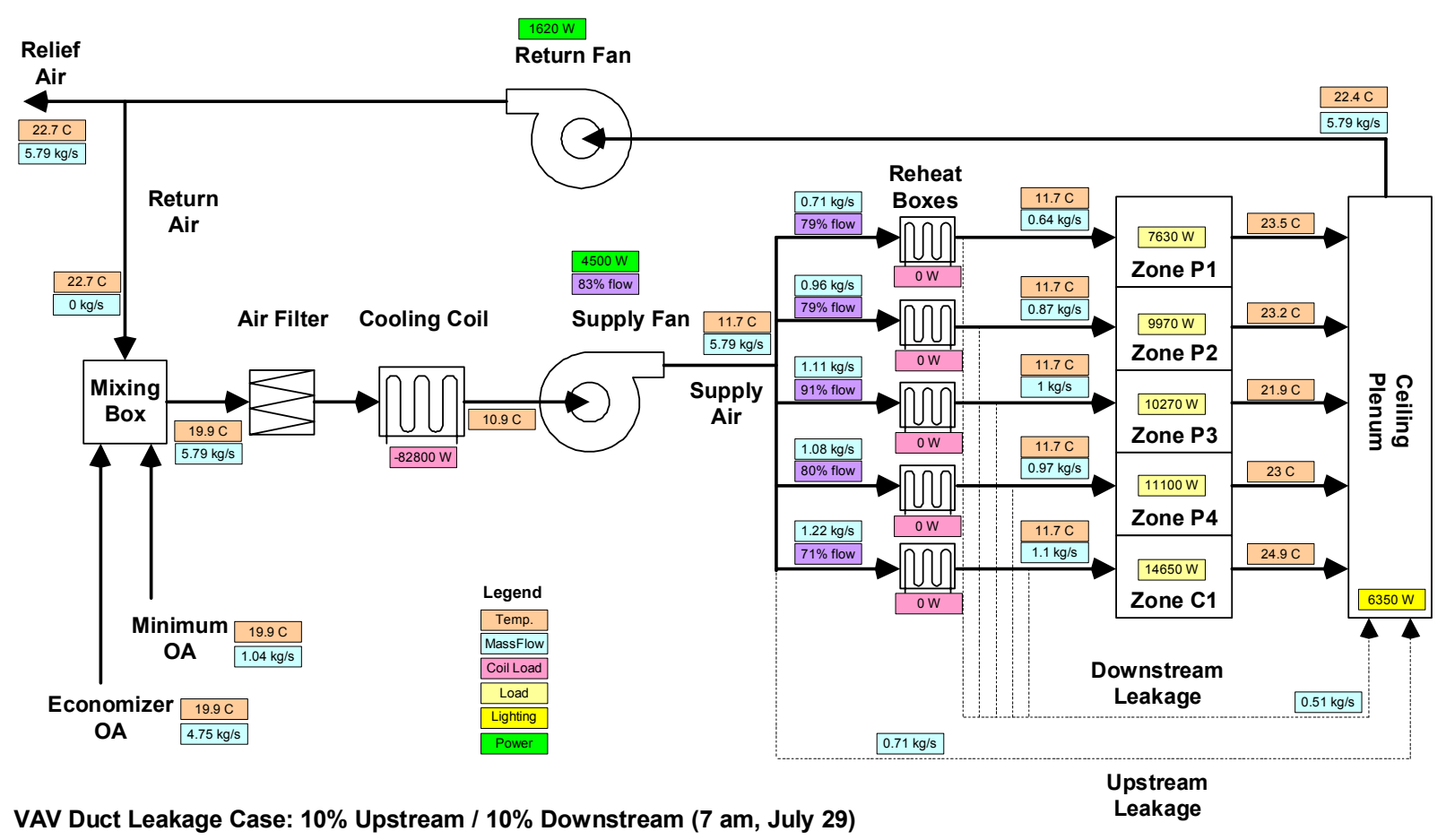

Figure 9. Sample TRNSYS Output - Cooling Hour 


\section{Dominant Downstream Leakage}

The effect on fan power of only increasing the downstream leakage is shown in Figure 10. In this case, the downstream leakage is increased from $2.5 \%$ leakage to $10 \%$ leakage, while the $2.5 \%$ upstream leakage remains unchanged. The total leakage with the increased downstream leakage is about $12 \%$.

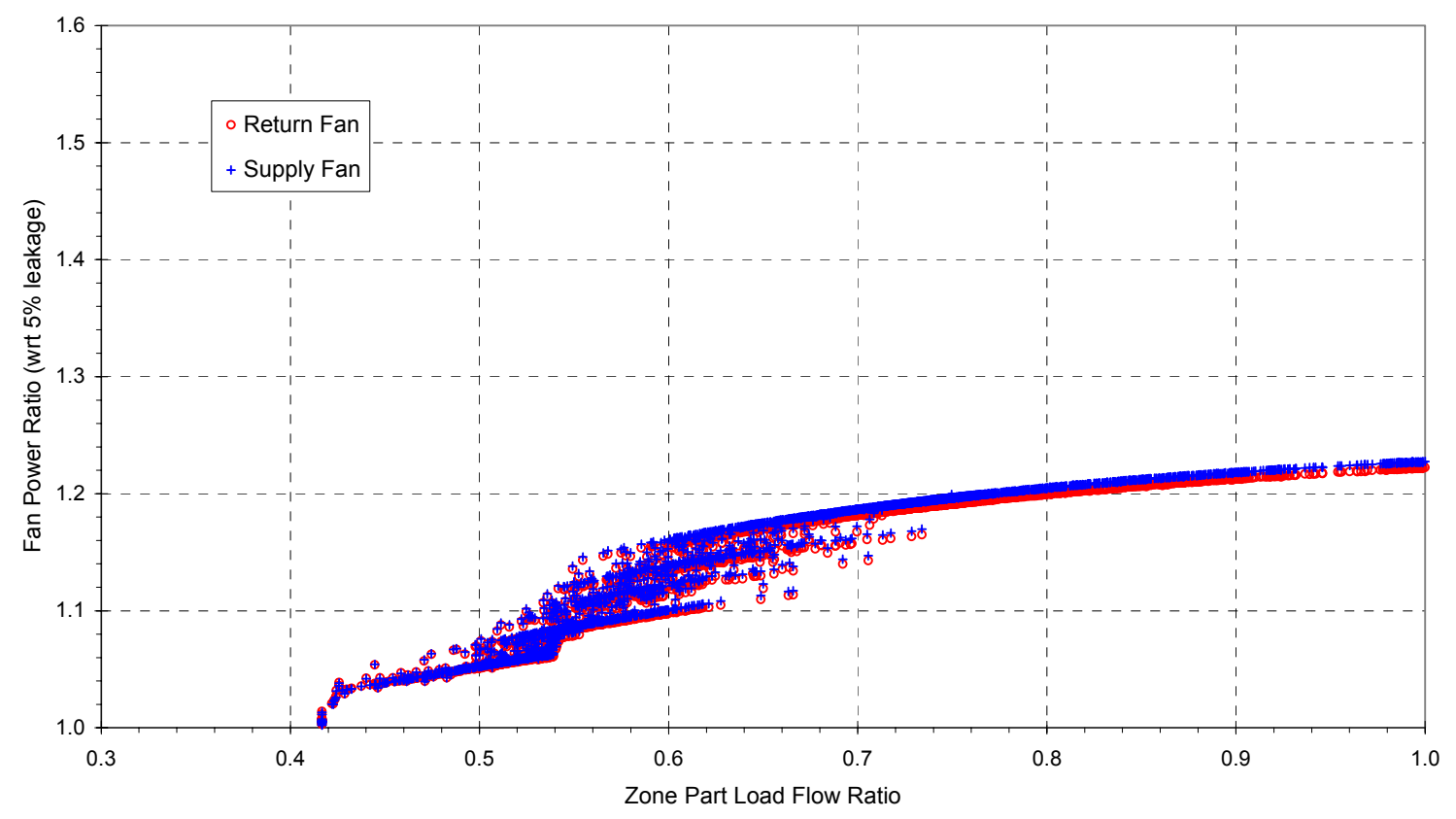

Figure 10. Dominant Downstream Leakage (2.5+10) - Fan Power Impacts

Compared to the tight duct system (5\% total leakage) at design conditions (zone part load flow of $1.0)$, Figure 10 shows that the added downstream leakage increases supply and return fan power about $23 \%$. The fan power increases are reduced as the zone-part-load-flow ratio decreases and, at part loads less than about 0.73 , the curves become quite scattered. At the average zone-partload-flow ratio (0.65), the power increases for both fans are in a broad range of about 11 to $18 \%$. Because the two fans behave similarly, the fractional increase in total fan power is similar to the average fractional increase for the supply and return fans at any particular zone-part-load-flow ratio. The average increase in total fan power for this dominant downstream leakage case is about $14 \%$.

The supply fan power ratios increase as the zone part load flow ratios increase, because as Figure 11 shows, the downstream leakage airflow and therefore supply fan airflows increase more with increasing part load than for the tight duct system (the downstream leakage is a fixed fractional flow, but not a fixed flow rate). Because the return fan mass flow (not shown in Figure 11) is the same as the supply fan mass flow, the return fan power ratios increase in a similar manner.

The scatter at a given zone-part-load-flow ratio occurs because there are some hours when no supply air reheating is needed and all the VAV boxes are supplying more than their minimum turndown flow, and there are other hours at the same zone-part-load-flow ratio when one or more of the zones requires reheat and the corresponding VAV boxes are providing only the minimum turn down flow. In the latter circumstance, because the VAV box airflow is constant, increased leakage flows downstream of these boxes do not increase the supply and return fan airflows, and 
therefore the leakage downstream of these boxes does not increase fan power. However, for the other VAV boxes that are not at their minimum turndown, increased leakage flows downstream of these boxes do increase the supply and return fan airflows, and therefore do increase fan power.

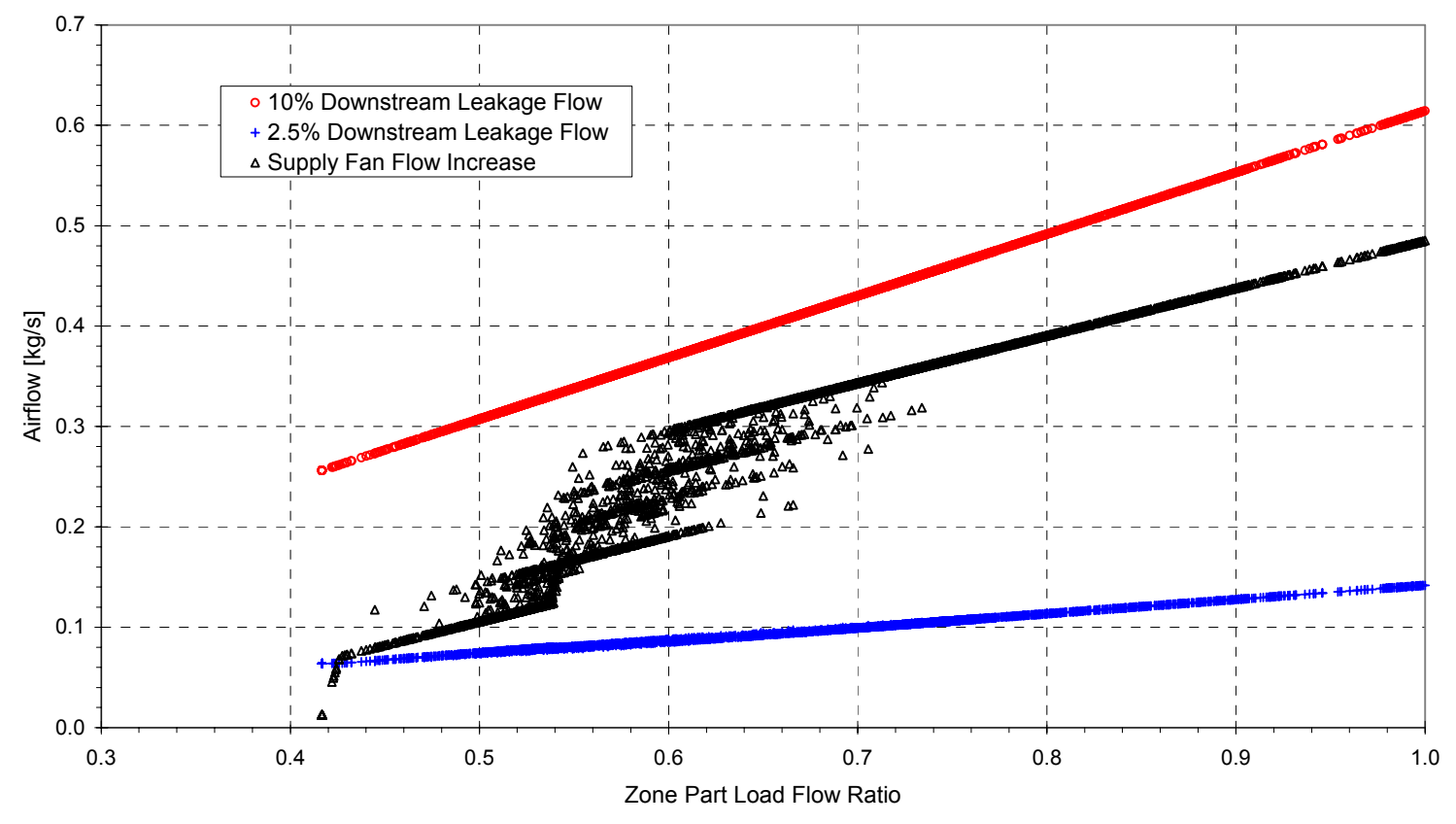

Figure 11. Dominant Downstream Leakage (2.5+10) - Airflow Impacts

To illustrate the behavior when there is some reheating, Figures 12 and 13 show a sample of the performance parameters calculated by TRNSYS for a cooling hour with reheat during January at the average zone-part-load-flow ratio (0.65), for the 2005 Title 24 Sacramento building. Figure 12 shows a tight duct system (about 5\% total leakage); Figure 13 shows the same system, but with leaky downstream ducts (about 12\% total leakage). In this example, the increase in total fan power with the increased downstream leakage is about $11 \%$.

A positive consequence of downstream duct leakage is that the amount of reheating required will be reduced for the leaky system, because the supply airflows entering the zones with reheat are less than for the tight system and less overcooling will occur due to the airflow entering the zone. This consequence of downstream leakage actually causes system reheat loads to decrease slightly, as shown in Figures 12 and 13 and as noted in the annual energy consumption comparisons discussed in Section 6.2. On the other hand, it is worth noting that some zones do not receive their required minimum outdoor air through the HVAC system for the leaky duct case.

\section{Dominant Upstream Leakage}

The effect on fan power of only increasing the upstream leakage is shown in Figure 14. In this case, the upstream leakage is increased from $2.5 \%$ leakage to $10 \%$ leakage, while the $2.5 \%$ downstream leakage remains unchanged. The total leakage with the increased upstream leakage is about $12 \%$. 


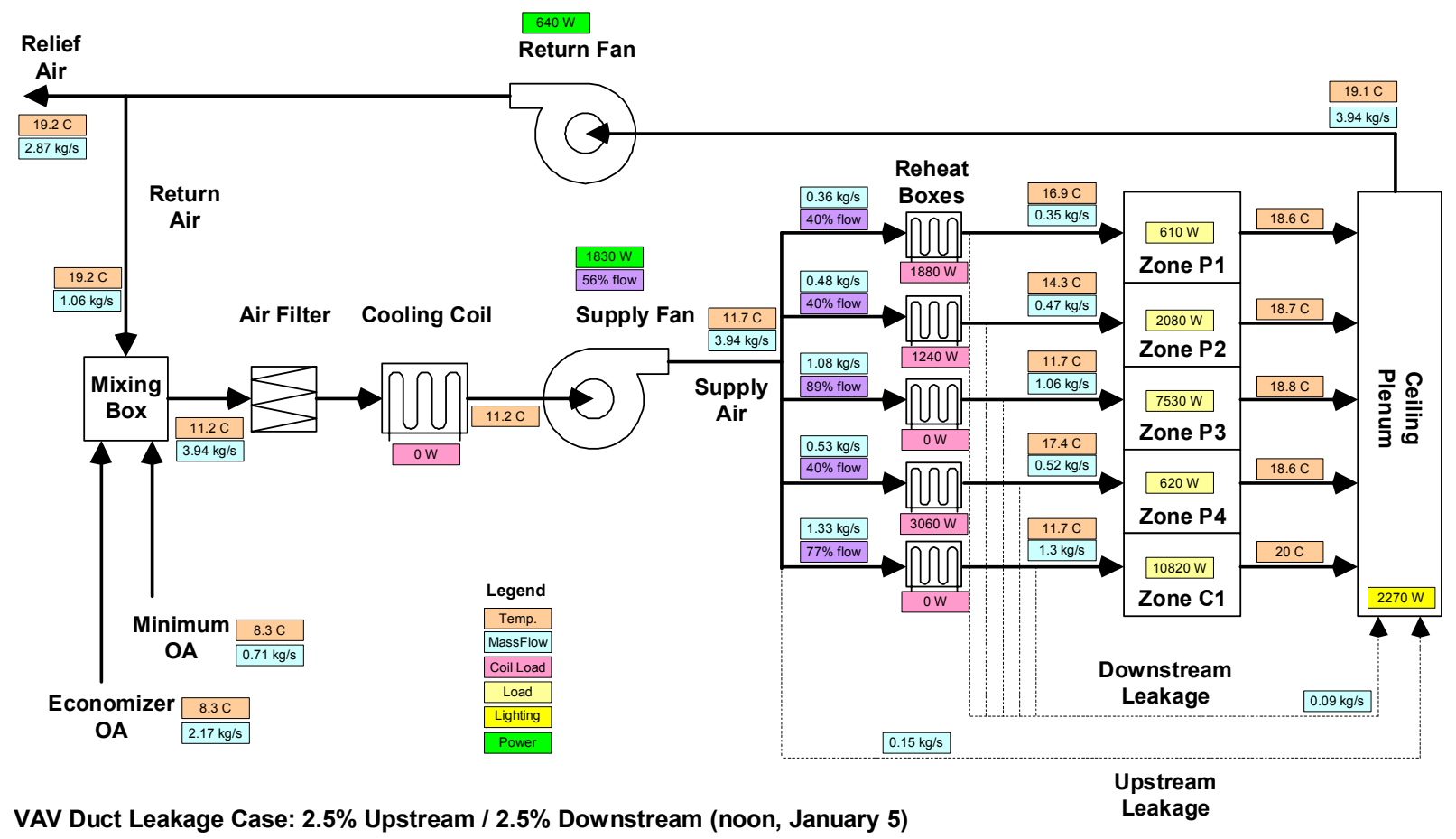

Figure 12. Tight Ducts $(2.5+2.5)$ - Cooling Hour with Reheat

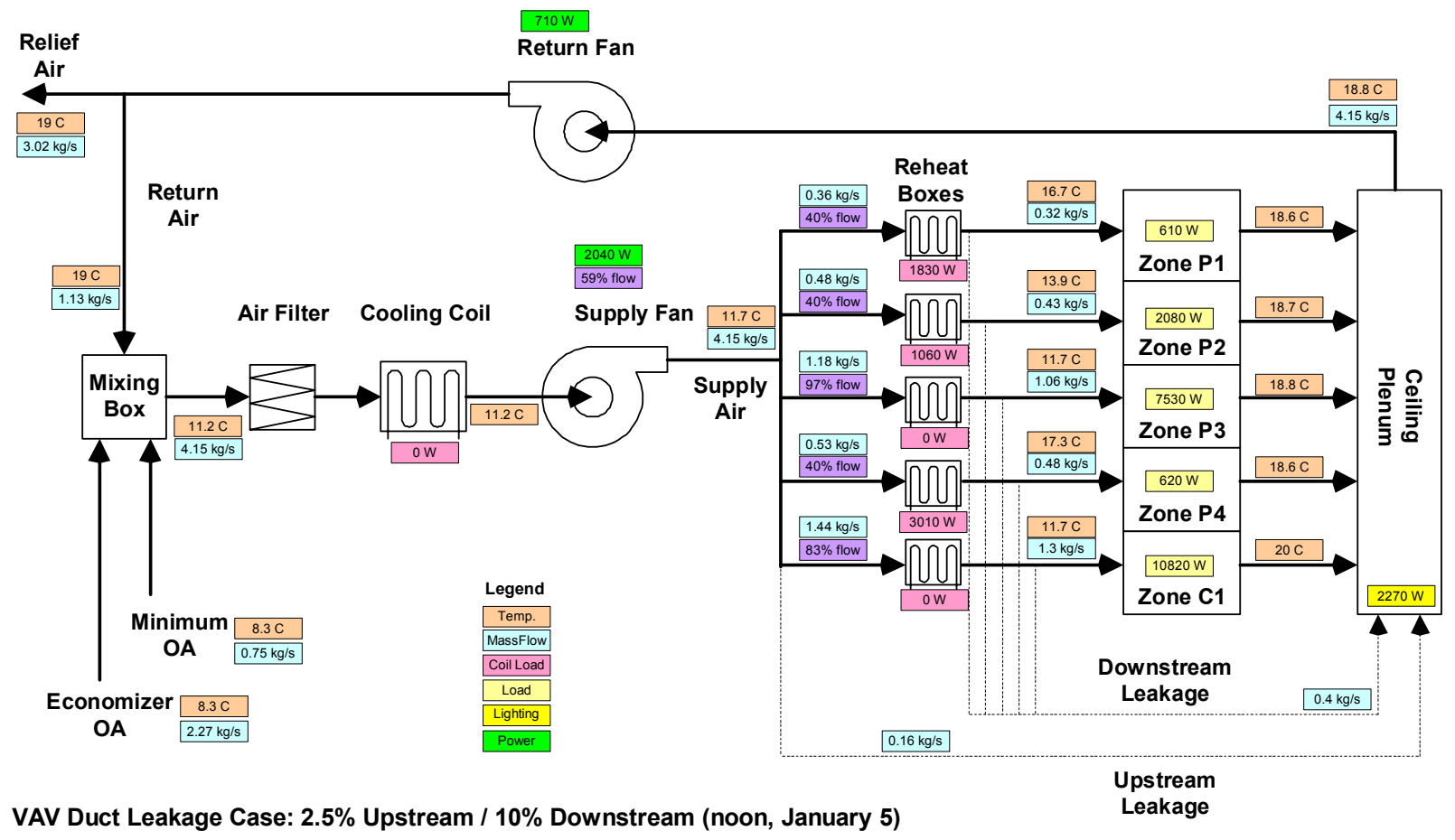

Figure 13. Dominant Downstream Leakage $(2.5+10)$ - Cooling Hour with Reheat 


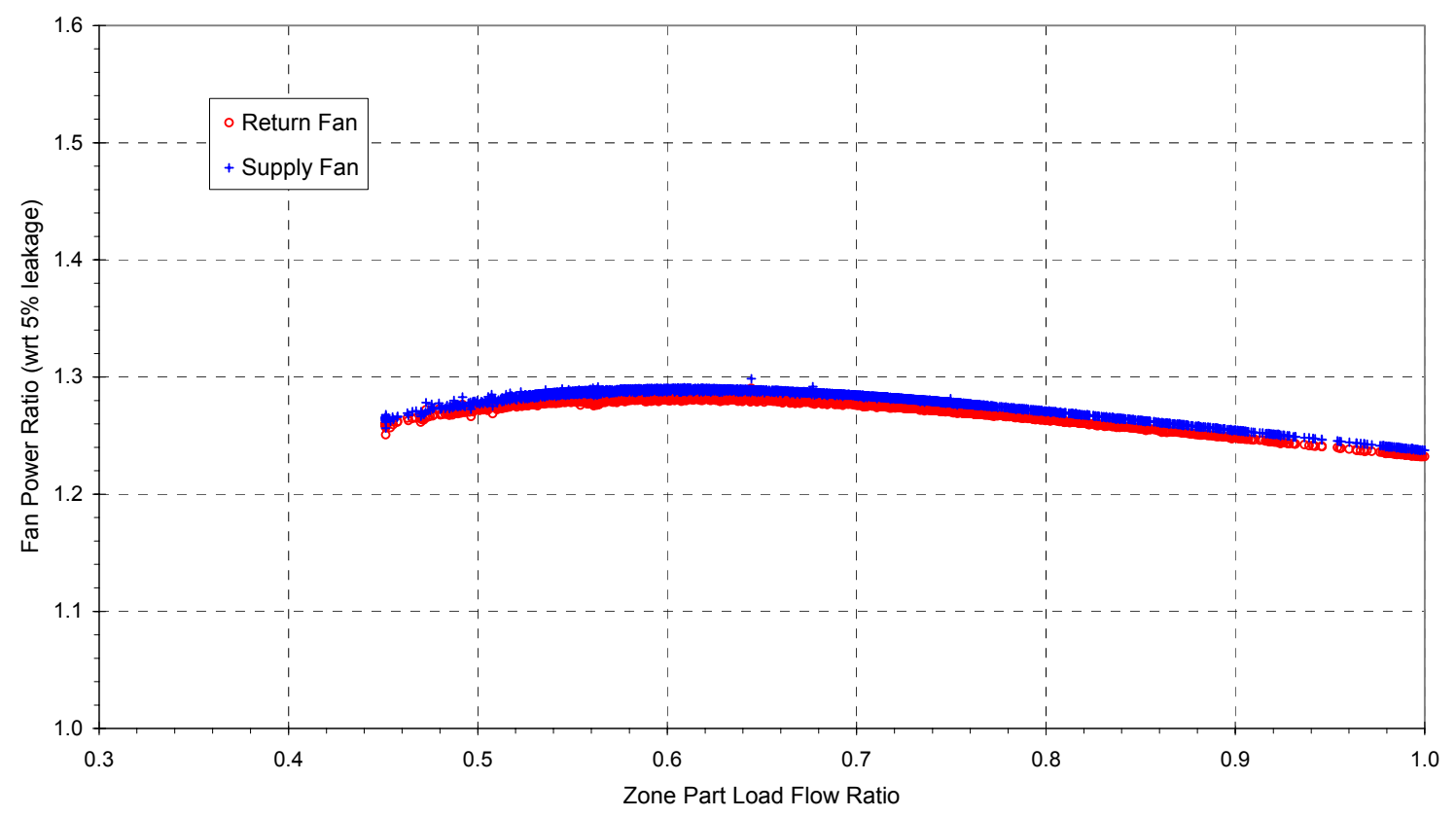

Figure 14. Dominant Upstream Leakage (10+2.5) - Fan Power Impacts

Compared to the tight duct system at design conditions, Figure 14 shows that the added upstream leakage increases supply and return fan power about $24 \%$. At the average zone-part-load-flow ratio (0.66), the power increases about $29 \%$ and $28 \%$ respectively for the supply and return fans. The average increase in total fan power for this dominant upstream leakage case is about $28 \%$.

The behavior with dominant upstream leakage is very different compared to the behavior for dominant downstream leakage. With a fixed leakage rate, the upstream leakage flow becomes a larger percentage of total airflow at lower zone-part-load-flow ratios. As a result, in the absence of downstream leakage, the fan power ratio would continually increase as the part load was reduced. However, the $2.5 \%$ downstream leakage in this case reduces the fan power ratio as the part load reduces, and the net effect is as shown in Figure 14.

\section{Combined Upstream and Downstream Leakage}

Figure 15 shows the results for the 10+10 leakage case (about 19\% total leakage), which combines the separate effects of dominant upstream leakage and dominant downstream leakage on fan power consumption. Overall, the increase in fan power due to the combined leakage is greater at all zone-part-load-flow ratios in this case than in either the dominant downstream or dominant upstream leakage cases described earlier. Compared to the tight duct system at design conditions, the supply and return fan power increase about 53\% and 51\% respectively. At the average zone-part-load-flow ratio (0.65), the total fan power increase due to leakage ranges from 45 to $54 \%$. The average increase in total fan power for this combined leakage case is about $50 \%$.

Figures 16 and 17 show the results for the 7.5+7.5 and 5+5 leakage cases (about 14\% and 10\% total leakage respectively). Compared to the $10+10$ case, as the downstream leakage fractions decrease, the scatter decreases significantly; the impact on reheat coil loads also decreases significantly. The average increase in total fan power for these two cases is about $30 \%$ and $13 \%$ respectively. 


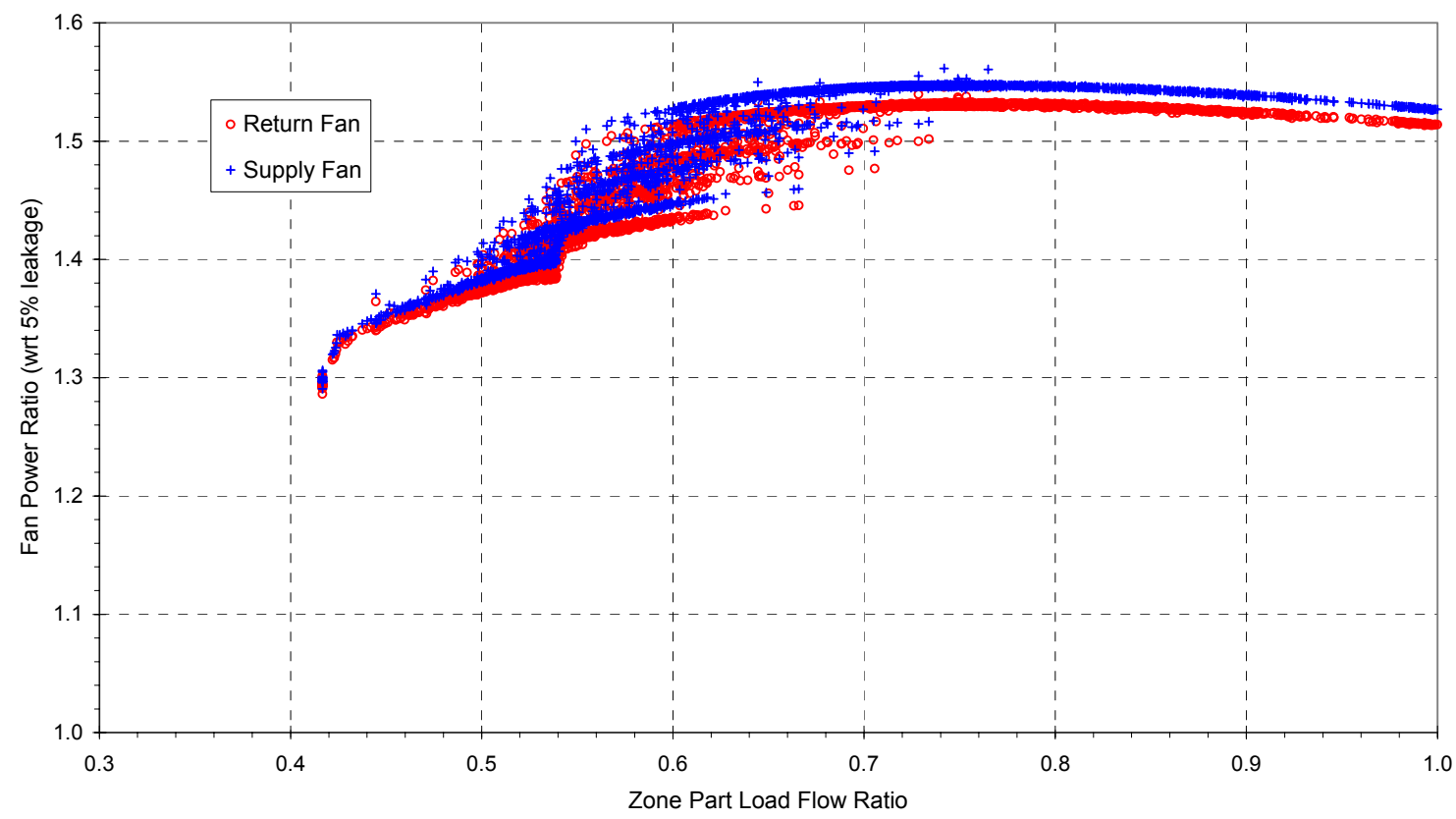

Figure 15. Upstream and Downstream Leaks (10+10) - Fan Power Impacts

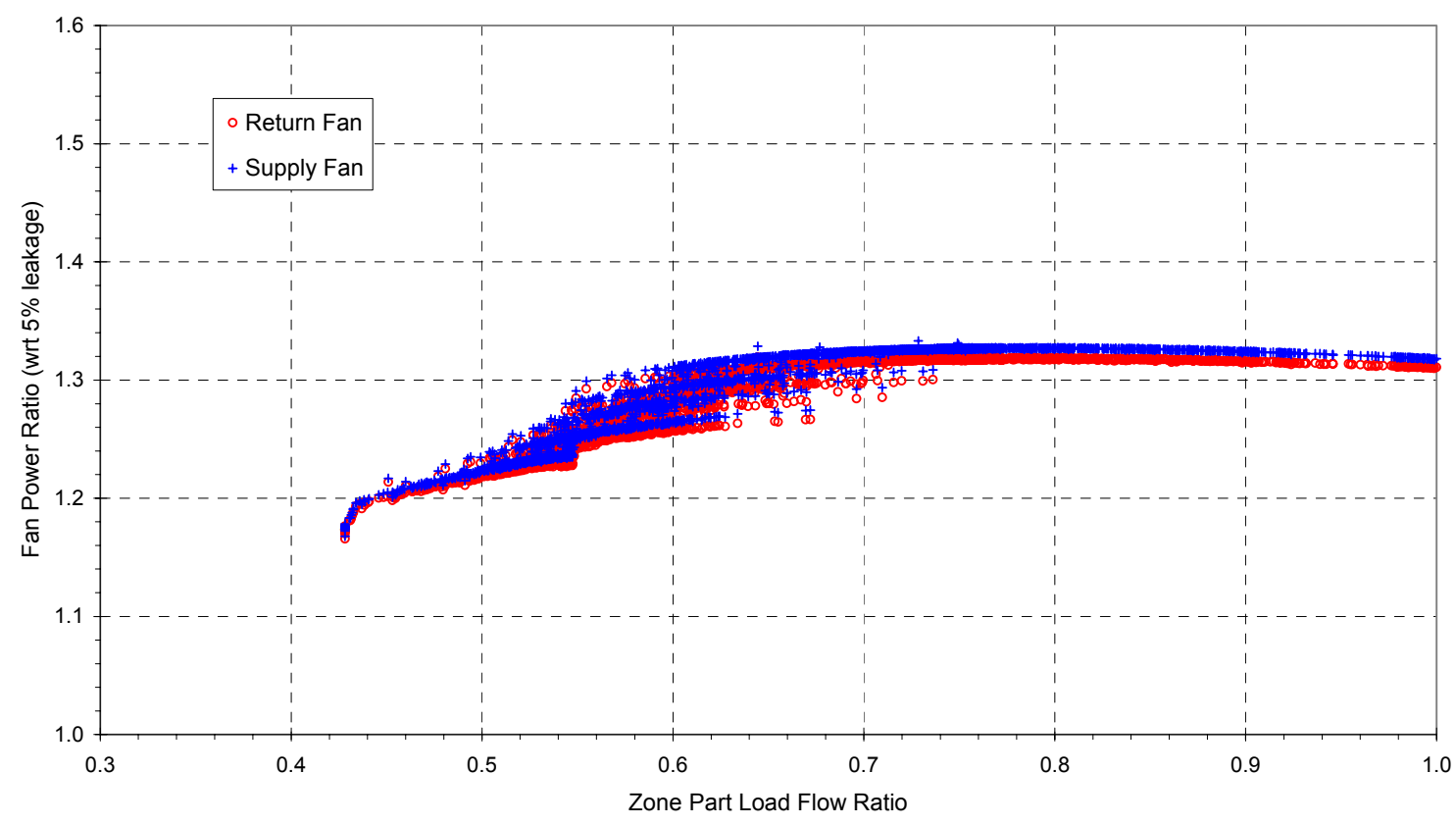

Figure 16. Upstream and Downstream Leaks (7.5+7.5) - Fan Power Impacts 


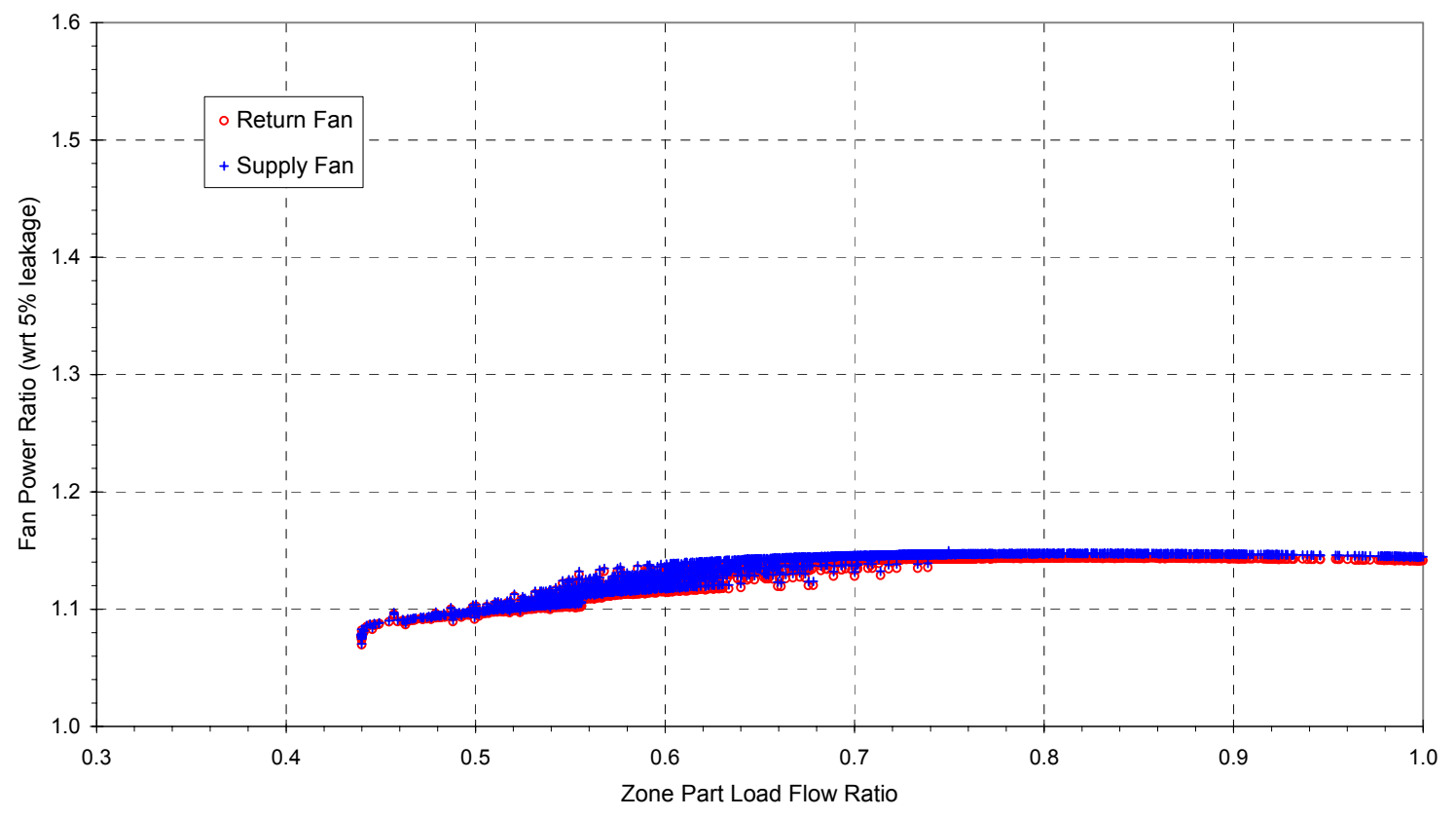

Figure 17. Upstream and Downstream Leaks (5+5) - Fan Power Impacts

\subsection{Energy Consumption}

Table III-1 in Appendix III summarizes the VAV distribution system energy performance for the 54 cases that we studied; the fractional energy uses by component and the energy increases due to duct leakage are listed in Tables III-2a and III-2b. The total HVAC site energy use reported includes supply and return fan electricity consumption, chiller and cooling tower electricity consumption, boiler electricity consumption, and boiler natural gas consumption. It does not include exhaust fan electricity consumption, which we did not model.

The coil loads listed in Table III-1 are large compared to total fan energy, but do not reflect enduse energy. However, the cooling and reheat coil loads can be related to plant site energy consumption by using the system-to-plant regression equations that we developed. Once this translation from coil loads to plant energy is made, Tables III-2a and III- $2 b$ show that annual total energy consumption for supply and return fans ranges from 10 to $25 \%$ of the total HVAC system energy consumption (17 to $33 \%$ of the total HVAC system electrical energy use). Annual cooling plant energy is the largest energy use component and ranges from 44 to $60 \%$ of the total HVAC system energy consumption ( 65 to $81 \%$ of the total HVAC system electrical energy use).

For comparison, California Energy Commission Year 2000 data (Brook 2002) indicate that about $36 \%$ of HVAC-related site electricity consumption in California's large commercial buildings is used by supply, return, and exhaust fans. Supply and return fans use about $60 \%$ of this fanrelated energy, or about $22 \%$ of HVAC-related electricity consumption. This latter fraction is consistent with the midpoint of our range (17 to 33\%). If we assume that the buildings that we simulated would use exhaust fan energy in the same proportion to supply and return fan energy as indicated by the CEC data, then our 17 to $33 \%$ supply and return fan energy fraction means that fans (supply, return, and exhaust) would use about 28 to 55\% of HVAC-related electricity consumption. 
Of particular interest are the fractional changes in site energy use resulting from duct leakage. These values are presented in the seven right-hand columns of Tables III-2a and III- $2 \mathrm{~b}$. For 10+10 leakage, total fan energy increases by 40 to $50 \%$. Cooling plant energy also increases ( 7 to $10 \%$ ), but reheat energy decreases (3 to 10\%). As described in the earlier discussion about dominant downstream leakage (Section 6.1), the reheat energy decreases with duct leakage due to VAV box operation at minimum turn down flows during reheating. In combination, the effect of fan and cooling energy increases (electrical), offset by reheat energy decreases (natural gas), increases total HVAC energy use by 2 to $14 \%$ for this case.

Compared to the significant increases in the $10+10$ case, the increases are much smaller for $5+5$ leakage: total fan energy increases by 10 to $14 \%$, cooling plant energy increases by 2 to $3 \%$, reheat energy decreases by 1 to $4 \%$, and total HVAC energy increases by 0 to $4 \%$.

In almost half the cases, the reheat energy decrease exceeds the corresponding cooling plant energy increase, particularly when downstream leakage is large. In a few cases, added duct leakage actually results in a slight reduction in total HVAC energy use compared to the tight duct case.

\subsection{Equipment Sizing Considerations}

An additional effect that duct leakage has on system performance is to increase the required size of system components. Tables IV-1a and IV-1b in Appendix IV summarize the maximum fan, VAV box, and zone airflows and the peak coil loads that occur over the annual simulation for the 54 cases that we analyzed. The impacts of duct leakage are presented in the four right-hand columns (fan airflows, VAV box airflows, and coil sizes), relative to the tight leakage case.

The fan size requirement increases by about 16 to $21 \%$ for $10+10$ leakage. Both cooling and reheat coil size requirements increase: 7 to $12 \%$ for the cooling coil, and 2 to $6 \%$ for the reheat coils. Compared to the significant increases in the 10+10 case, the equipment size increases are much smaller for 5+5 leakage: 5 to $6 \%$ for the supply fan, 2 to $3 \%$ for the cooling coil, and 1 to $2 \%$ for the reheat coil.

The size increases (especially for the $10+10$ case) are important because they translate into increased equipment capital costs, which are in addition to the increased energy operating costs described below.

\subsection{HVAC System Operating Costs}

Using our system-to-plant energy regression equations with energy cost data enables us to extend the simulation results to estimate duct leakage impacts on HVAC system operating costs. In particular, we calculated annual operating costs using year 2000 average commercial sector energy prices for California: \$0.0986/kWh and \$7.71/Million Btu (EIA 2003). These prices include demand charges, averaged over the total consumption for the year. In the discussion that follows, we ignored the separate effects of energy demand changes on demand charges. If demand charges were included, we expect that the actual operating cost increases would be larger than those reported here, because the largest fractional increases in energy use coincide with medium to full load operation of the HVAC system.

It is important to note that, because electrical energy costs much more (a factor of 3.7) than natural gas per unit of energy, the energy prices change the weighting of the energy contributions to the operating cost increases. Consequently, even the low total HVAC energy increases described in Section 6.2 still result in substantial cost increases in all but a few cases. 
Tables V-1a and V-1b in Appendix V present our estimates of HVAC system annual operating costs for the various leakage cases, along with the changes in cost relative to the tight duct case. The combined chiller and cooling tower operating cost increase is equal to about half of the combined supply and return fan cost increase. Including the cost decreases associated with the heating plant, the total plant energy cost increase equals about one-third of the fan cost increase. For the 10+10 leakage case, HVAC system annual operating costs increase by 9 to $18 \%(\$ 7,400$ to $\$ 9,500)$ relative to the tight duct case. The increase for $5+5$ leakage is 2 to $5 \%(\$ 1,800$ to $\$ 2,700)$.

The fractional and absolute cost increases do not necessarily correspond with each other, because the operating costs differ depending on building location and construction. For example, in the $10+10$ leakage case, Tables V-1a and V-1b show that the $9 \%$ fractional cost increase is achieved by a $\$ 7,500$ increase relative to an $\$ 87,000$ "tight duct" operating cost ("new" Pasadena CZ9 building); the $18 \%$ fractional cost increase is achieved by an $\$ 8,200$ increase relative to a $\$ 44,600$ operating cost ("Title 24" Oakland CZ3 building). The $\$ 7,400$ absolute cost increase is relative to a $\$ 63,300$ operating cost ("Title 24 " Pasadena CZ9 building) and corresponds to a fractional increase of about $12 \%$; the $\$ 9,500$ absolute increase is relative to a $\$ 77,300$ operating cost ("old" Sacramento CZ12 building) and also corresponds to a fractional increase of about $12 \%$.

\subsection{Duct Sealing Cost Effectiveness}

Figure 18 shows the range of increases in HVAC system annual operating costs due to leakage for all climates and building vintages, relative to the tight duct system (about $5 \%$ total leakage).

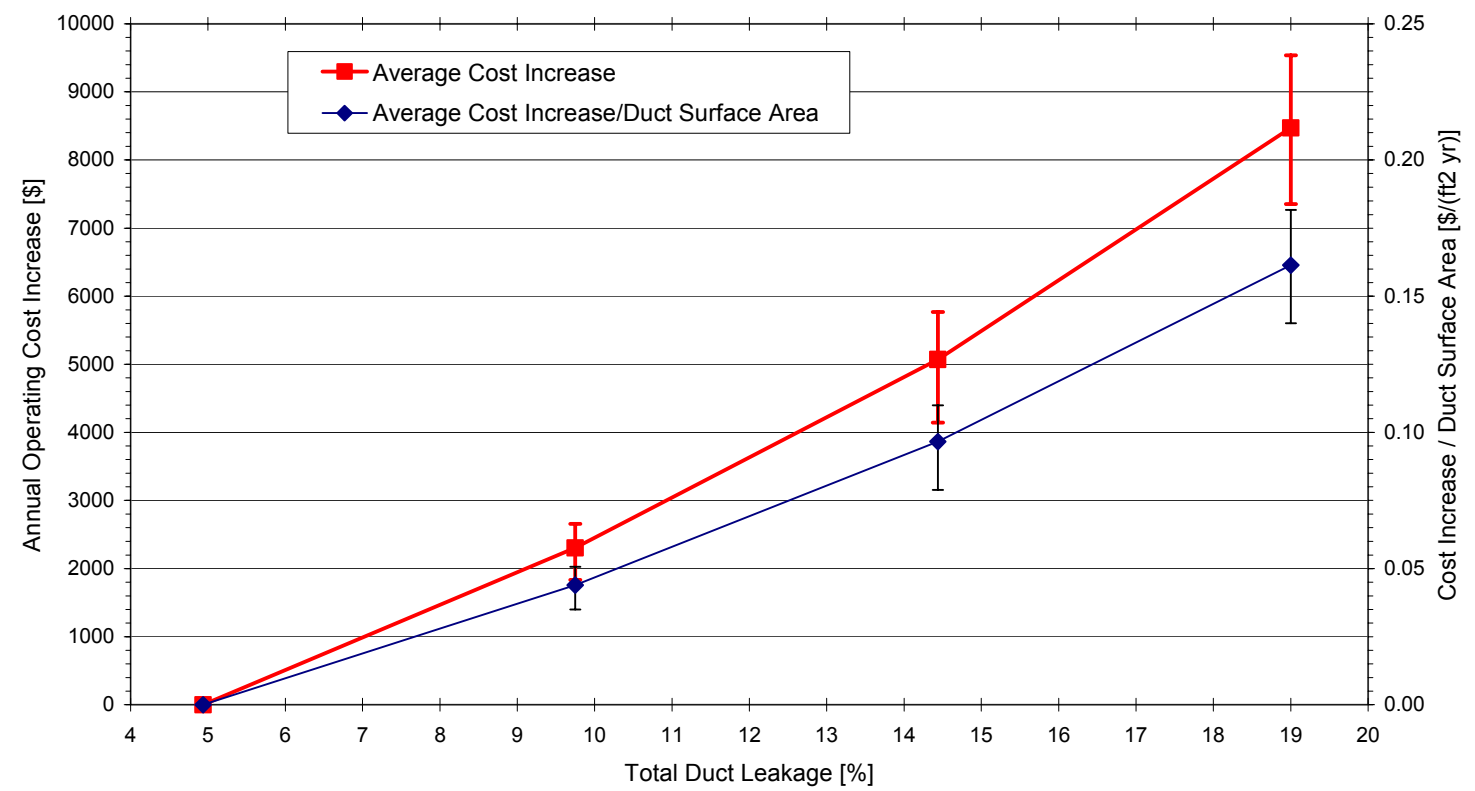

Figure 18. Duct Leakage Impacts on Annual HVAC Operating Costs

The values shown in Figure 18 assume that each floor's HVAC system, which serves 15,000 $\mathrm{ft}^{2}$ of conditioned floor area, has a duct surface area of 5,250 $\mathrm{ft}^{2}$. This surface area is based on commercial duct characterization data (Fisk et al. 2000). For large commercial HVAC systems, duct surface area ranges from 27 to $43 \%$ of the building floor area, and the area downstream of 
the VAV boxes ranges from 50 to $75 \%$ of the total duct surface area. Using typical ratios of $35 \%$ for the duct to floor area and $60 \%$ for the downstream duct area fraction, the duct surface area is $2,100 \mathrm{ft}^{2}$ upstream and 3,150 $\mathrm{ft}^{2}$ downstream. Based on the total duct surface area $\left(5,250 \mathrm{ft}^{2}\right)$, the operating costs compared to the tight system increase by 0.03 to $0.05 \$ / \mathrm{ft}^{2}$ for the $5+5$ leakage case, 0.08 to $0.11 \$ / \mathrm{ft}^{2}$ for the $7.5+7.5$ case, and 0.14 to $0.18 \$ / \mathrm{ft}^{2}$ for the $10+10$ leakage case.

Duct sealing costs vary with fitting-to-straight-duct ratio, pressure class, and other system variables. Tsal et al. (1998) have suggested that an upper bound for the one-time cost of duct sealing is $\$ 0.25 / \mathrm{ft}^{2}$ of duct surface area. SMACNA has suggested that a reasonable average sealing cost is $\$ 0.20 / \mathrm{ft}^{2}$ for new commercial installations (Stratton 1998). SMACNA could not provide a sealing cost estimate for retrofitting existing systems due to wide cost variations resulting from system variables and sealing methods.

Assuming a one-time duct sealing cost of $\$ 0.20 / \mathrm{ft}^{2}$, the average simple payback for the duct sealing is 5 years for the $5+5$ leakage case, 2 years for the $7.5+7.5$ case, and 1.3 years for the $10+10$ leakage case.

\section{CONCLUSIONS}

Our DOE-2/TRNSYS simulations indicate that a leaky VAV system (total leakage of about $19 \%$ ) will use about 40 to $50 \%$ more fan energy annually than a tight system (about 5\% leakage). Annual cooling plant energy also increases by about 7 to $10 \%$, but reheat energy decreases (about 3 to 10\%). In combination, the increase in total annual HVAC site energy is 2 to $14 \%$. The total HVAC site energy use includes supply and return fan electricity consumption, chiller and cooling tower electricity consumption, boiler electricity consumption, and boiler natural gas consumption.

Using year 2000 average commercial sector energy prices for California $(\$ 0.0986 / \mathrm{kWh}$ and \$7.71/Million Btu), the energy increases result in HVAC system annual operating cost increases ranging from 9 to $18 \%(\$ 7,400$ to $\$ 9,500)$. The low increases in total energy correspond to cases with large reductions in natural-gas-based reheat energy consumption due to the added leakage; the reheat reductions tend to offset the large electrical-based fan and cooling plant energy increases due to the added leakage. However, because electrical energy costs much more than natural gas per unit of energy, even the low total energy increases still result in substantial cost increases.

Normalized by duct surface area, the increases in HVAC system annual operating costs are 0.14 to $0.18 \$ / \mathrm{ft}^{2}$ for the $19 \%$ leakage case. Using a suggested one-time duct sealing cost of $\$ 0.20 / \mathrm{ft}^{2}$ of duct surface area, these results indicate that sealing leaky ducts in VAV systems has a simple payback period of about 1.3 years. Even with total leakage rates as low as $10 \%$, duct sealing is still cost effective. This suggests that duct sealing should be considered at least for VAV systems with $10 \%$ or more total duct leakage.

\section{OTHER ISSUES AND IMPLICATIONS}

Before duct performance in large commercial buildings can be accounted for in Title 24 nonresidential building energy standards, there are several issues that must be addressed and resolved. These include:

1. Specifying reliable duct air leakage measurement techniques that can be practically applied in the large commercial building sector. 
2. Defining the duct leakage condition for the standard building used in Title 24 compliance simulations.

3. Assuring consistency between simulated duct performance impacts and actual impacts.

4. Developing compliance tests for the Alternative Calculation Method (ACM) Approval Manual (CEC 2001b) to evaluate duct performance simulations.

Regarding Issues 1 and 2, new duct air leakage measurement techniques for large commercial buildings are already under development at LBNL. These efforts are focused on developing a rapid technique that measures leakage flows rather than leakage area, and we expect that it could be used to populate a database of duct leakage conditions in the existing building stock.

After the "typical" duct leakage for the building stock is defined, then a decision can be made about what duct leakage level to assign to the standard building. If the standard building description includes a typical duct air leakage rate, then proposed buildings will be rewarded for sealing ducts. If instead the standard building has a reduced leakage level, proposed buildings that are not sealed will be penalized. The decision about what leakage level to assume for the standard building description will depend upon the preparedness of the market to handle required duct efficiency improvements, as opposed to optional improvements.

In terms of prescriptive compliance options, if the standard-building duct performance parameters are established to correspond to typical duct air leakage, determining compliance using the prescriptive approach is straightforward. If the proposed building has a typical duct air leakage level and has ducts insulated to Title 24 requirements, the building complies with respect to ducts. In other words with nothing done to improve duct performance in the building, it would meet the minimal duct performance level in this case. On the other hand, if the standard building has tighter-than-typical duct air leakage specifications, then compliance would require either performance measurements (i.e., duct air leakage measurements), or increased energy efficiency of other building components.

With the standard building defined as having leaky ducts, improving the duct performance in the proposed building affects compliance only if the performance budget approach is used. If leaks are sealed as a compliance conservation measure, standardized testing methods must be adopted for the verification of reduced leakage rates. Leakage rates determined from the tests would be part of the duct performance input data in the performance compliance analysis for the proposed building.

For Issue 3, one study has already shown through detailed minute-by-minute field measurements in a large commercial building that duct leakage has a significant impact on HVAC system performance (Diamond et al. 2003). The extensive set of HVAC system performance data collected by Diamond et al. could be used to validate simulation tools that are used to predict the duct performance impacts.

Regarding Issue 4, several tests must be performed already on alternative calculation methods before they are approved. Although a test does not yet exist, the proper modeling of duct performance in these alternative methods should be evaluated as part of these capability tests. Given that the current two certified nonresidential compliance tools depend upon DOE-2.1E as the reference evaluation program, and that DOE-2.1E cannot properly account for duct thermal performance, it is expected that results obtained using an alternative calculation method that properly accounts for duct thermal performance might differ substantially from the reference program results. Thus, we recommend that a new reference program be identified for use at least 
in this test (e.g., EnergyPlus). A prerequisite in this case is that the reference method be appropriately validated against field measurements.

Three additional steps will be required to further develop duct-modeling capabilities that address limitations in existing models and to initiate strong market activity related to duct system improvements. We recommend that these steps include:

1. Implementing duct models in user-friendly commercially-available software for building energy simulation, validating the implementations with case studies and demonstrations, and obtaining certification for software use as a primary or alternative compliance tool in support of the Title 24 Nonresidential Standards.

2. Developing methodologies to deal with airflows entering VAV boxes from ceiling return plenums (e.g., to model parallel fan-powered VAV boxes), to deal with duct surface heat transfer effects, and to deal with static pressure reset and supply air temperature reset strategies.

3. Transferring information to practitioners through publications, conferences, workshops, and other education programs.

\section{GLOSSARY}

ACM Alternative Calculation Method

ASHRAE American Society of Heating, Refrigerating, and Air-Conditioning Engineers

CAV Constant Air Volume

CEC California Energy Commission

DOE U.S. Department of Energy

EDS Efficient Distribution Systems

EIA Energy Information Administration

GWh Giga Watt hours, $10^{9} \mathrm{Wh}, 10^{6} \mathrm{kWh}$

HVAC Heating, ventilating, and air conditioning

LBNL Lawrence Berkeley National Laboratory

MW Mega Watt, $10^{6} \mathrm{~W}$

PIER Public Interest Energy Research

SMACNA Sheet Metal and Air Conditioning Contractors' National Association VAV Variable Air Volume

\section{REFERENCES}

1. Brandemuehl, M.J., S. Gabel, and I. Andresen. 1993. "HVAC 2 Toolkit: Algorithms and Subroutines for Secondary HVAC System Energy Calculations". American Society of Heating, Refrigerating and Air-Conditioning Engineers, Inc.

2. Brook, M. 2002. "California Electricity Outlook: Commercial Building Systems". Presentation at PIER Buildings Program HVAC Diagnostics Meeting, Oakland, CA. April 16. 
3. CEC. 2001a. "Nonresidential Manual for Compliance with the 2001 Energy Efficiency Standards (for Nonresidential Buildings, High-Rise Residential Buildings, and Hotels/Motels)". California Energy Commission, P400-01-023, August.

4. CEC. 2001b. "Alternative Calculation Method (ACM) Approval Manual for the 2001 Energy Efficiency Standards for Nonresidential Buildings”. California Energy Commission, P400-01-011, April.

5. CEC. 2003a. "2005 Building Energy Efficiency Standards - Standards for Residential and Nonresidential Buildings". Consultant Draft Report, Workshop Draft 3, P400-03-001D3, February.

6. CEC. 2003b. "2005 Building Energy Efficiency Standards - Nonresidential ACM Manual Workshop Draft'. California Energy Commission, P400-03-004D, February 4.

7. Diamond, R., C. Wray, D. Dickerhoff, N. Matson, and D. Wang. 2003. "Thermal Distribution Systems in Commercial Buildings". Lawrence Berkeley National Laboratory Report, LBNL-51860.

8. EIA. 2003. "State Energy Data 2000 Price and Expenditure Data". Energy Information Agency, U.S. Department of Energy.

9. EIA. 2002. "1999 Commercial Buildings Energy Consumption Survey - Detailed Tables". Energy Information Administration, U.S. Department of Energy. August. http://www.eia.doe.gov/emeu/cbecs/pdf/alltables.pdf

10. Fisk, W.J., W. Delp, R. Diamond, D. Dickerhoff, R. Levinson, M. Modera, M. Nematollahi, and D. Wang. 2000. "Duct Systems in Large Commercial Buildings: Physical Characterization, Air Leakage, and Heat Conduction Gains". Energy and Buildings, Vol. 32, No. 1. LBNL-42339.

11. Franconi, E., W. Delp, and M. Modera. 1998. "Impact of Duct Air-Leakage on VAV System Energy Use”. Lawrence Berkeley National Laboratory Draft Report. LBNL-42417.

12. Franconi, E.M. 1999. "Thermodynamic Analysis for Improved HVAC Distribution System Performance". Ph.D. Dissertation, Department of Civil, Environmental, and Architectural Engineering, University of Colorado, Boulder.

13. Grot, R.A. and A.K. Persily. 1986. "Measured Air Infiltration and Ventilation Rates in Eight Large Office Buildings". American Society for Testing and Materials. ASTM STP 904, Measured Air leakage of Buildings, H.R. Treschel and P.L. Lagus, eds.

14. Huang, Y.J. 2003. Personal Communication. Lawrence Berkeley National Laboratory.

15. Huang, J. and E. Franconi. 1999. "Commercial Heating and Cooling Loads Component Analysis”. Lawrence Berkeley National Laboratory Report, LBL-37208.

16. Klein, S.A., W.A. Beckman, J.W. Mitchell, J.A. Duffie, N.A. Duffie, T.L. Freman, J.C. Mitchell, J.E. Braun, B.L. Evans, J.P. Kummer, R.E. Urban, A. Fiskel, and J.W. Thornton. 1996. “TRNSYS: A Transient System Simulation Program". Solar Energy Laboratory, University of Wisconsin-Madison. Version 14.2.

17. Knebel, D.E. 1983. "Simplified Energy Analysis using the Modified Bin Method". Atlanta: American Society of Heating, Refrigerating and Air-Conditioning Engineers, Inc. 
18. Kreider, J.F. and A. Rabl. 1994. "Heating and Cooling of Buildings: Design for Efficiency”. New York: McGraw-Hill.

19. Modera, M.P. 2002. "Proposed Revisions to 2005 Title 24 Energy Efficiency Standards: Addition of HVAC Transport Efficiency Concept". Memorandum to the California Energy Commission. October 31.

20. Modera, M. T. Xu, H. Feustel, N. Matson, C. Huizenga, F. Bauman, E. Arens, and T. Borgers. 1999. "Efficient Thermal Energy Distribution in Commercial Buildings". Lawrence Berkeley National Laboratory Report to California Institute for Energy Efficiency, LBNL-41365. August.

21. Pedersen, C.O., D.E. Fisher, J.D. Spitler, and R.J. Liesen. 1998. "Cooling and Heating Load Calculation Principles". Atlanta: American Society of Heating, Refrigeration, and Air-Conditioning Engineers, Inc.

22. Pietsch, J.A. 1991. "Water-Loop Heat Pump Systems: Assessment Study Update”. Electric Power Research Institute, EPRI- CU- 7535, Project 2480- 2, Final Report.

23. Stratton, J.H. 1998. Personal Communication. Director of Technical Services, SMACNA, Chantilly, VA. October 1.

24. Tsal, R.J., H.F. Behls, and L.P. Varvak. 1998. "T-Method Duct Design: Part V: Duct Leakage Calculation Technique and Economics". ASHRAE Transactions, V. 104, Pt. 2. American Society of Heating, Refrigerating and Air-Conditioning Engineers, Inc.

25. Winkelmann, F.C., B.E. Birdsall, W.F. Buhl, K.L. Ellington., and A.E. Erdem. 1993 a. “DOE-2 BDL Summary Version 2.1E”. LBNL-34946. Berkeley, Calif.: Lawrence Berkeley National Laboratory.

26. Winkelmann, F., B. Birdsall, F. Buhl, K. Ellington, E. Erdem, J. Hirsch, and S. Gates. 1993b. “DOE-2 Supplement, Version 2.IE”. Lawrence Berkeley National Laboratory, LBL-34947, November. Also Springfield, Virginia: National Technical Information Service.

27. Xu, T., O. Bechu, R. Carrié, D. Dickerhoff, W. Fisk, E. Franconi, Ø. Kristiansen, R. Levinson, J. McWilliams, D. Wang, M. Modera, T. Webster, E. Ring, Q. Zhang, C. Huizenga, F. Bauman, and E. Arens. 1999. "Commercial Thermal Distribution Systems". Lawrence Berkeley National Laboratory Report to the California Institute for Energy Efficiency and the California Energy Commission. LBNL-44320. December.

28. Wray, C.P. 2003. "Duct Thermal Performance Models for Large Commercial Buildings". Lawrence Berkeley National Laboratory Report. LBNL-53410. 


\section{APPENDIX I: BUILDING SCHEDULES}

Table I-1. Heating Set-Point Schedule $\left({ }^{\circ}\right.$ F)

\begin{tabular}{|c|c|c|c|c|c|c|c|c|c|c|c|}
\hline \multicolumn{3}{|c|}{ Weekday } & \multicolumn{3}{|c|}{ Saturday } & \multicolumn{3}{|c|}{ Sunday } & \multicolumn{3}{|c|}{ Holiday } \\
\hline $\begin{array}{c}\text { Start } \\
(\mathrm{Hr})\end{array}$ & $\begin{array}{l}\text { Stop } \\
\text { (Hr) }\end{array}$ & Value & $\begin{array}{l}\text { Start } \\
(\mathrm{Hr})\end{array}$ & $\begin{array}{l}\text { Stop } \\
\text { (Hr) }\end{array}$ & Value & $\begin{array}{l}\text { Start } \\
(\mathrm{Hr})\end{array}$ & $\begin{array}{l}\text { Stop } \\
\text { (Hr) }\end{array}$ & Value & $\begin{array}{l}\text { Start } \\
(\mathrm{Hr})\end{array}$ & $\begin{array}{l}\text { Stop } \\
\text { (Hr) }\end{array}$ & Value \\
\hline 1 & 5 & 60 & 1 & 5 & 60 & 1 & 5 & 60 & 1 & 5 & 60 \\
\hline 6 & 7 & 65 & 6 & 16 & 65 & 6 & 16 & 65 & 6 & 16 & 65 \\
\hline 8 & 18 & 70 & 17 & 24 & 60 & 17 & 24 & 60 & 17 & 24 & 60 \\
\hline 19 & 19 & 65 & & & & & & & & & \\
\hline 20 & 24 & 60 & & & & & & & & & \\
\hline
\end{tabular}

Table I-2. Cooling Set-Point Schedule $\left({ }^{\circ}\right.$ F)

\begin{tabular}{|c|c|c|c|c|c|c|c|c|c|c|c|}
\hline \multicolumn{3}{|c|}{ Weekday } & \multicolumn{3}{c|}{ Saturday } & \multicolumn{3}{c|}{ Sunday } & \multicolumn{3}{c|}{ Holiday } \\
\hline $\begin{array}{c}\text { Start } \\
(\mathrm{Hr})\end{array}$ & $\begin{array}{c}\text { Stop } \\
(\mathrm{Hr})\end{array}$ & Value & $\begin{array}{c}\text { Start } \\
(\mathrm{Hr})\end{array}$ & $\begin{array}{c}\text { Stop } \\
(\mathrm{Hr})\end{array}$ & Value & $\begin{array}{c}\text { Start } \\
(\mathrm{Hr})\end{array}$ & $\begin{array}{c}\text { Stop } \\
(\mathrm{Hr})\end{array}$ & $\begin{array}{c}\text { Vtart } \\
\text { Value }\end{array}$ & $\begin{array}{c}\text { Stop } \\
(\mathrm{Hr})\end{array}$ & Value \\
\hline 1 & 5 & 77 & 1 & 5 & 77 & 1 & 5 & 77 & 1 & 5 & 77 \\
6 & 18 & 73 & 6 & 18 & 73 & 6 & 18 & 73 & 6 & 18 & 73 \\
19 & 24 & 77 & 19 & 24 & 77 & 19 & 24 & 77 & 19 & 24 & 77 \\
\hline
\end{tabular}

Table I-3. Lighting Schedule (Fraction of Full Intensity)

\begin{tabular}{|c|c|c|c|c|c|c|c|c|c|c|c|}
\hline \multicolumn{3}{|c|}{ Weekday } & \multicolumn{3}{|c|}{ Saturday } & \multicolumn{3}{c|}{ Sunday } & \multicolumn{3}{c|}{ Holiday } \\
\hline $\begin{array}{c}\text { Start } \\
(\mathrm{Hr})\end{array}$ & $\begin{array}{c}\text { Stop } \\
(\mathrm{Hr})\end{array}$ & Value & $\begin{array}{c}\text { Start } \\
(\mathrm{Hr})\end{array}$ & $\begin{array}{c}\text { Stop } \\
(\mathrm{Hr})\end{array}$ & Value & $\begin{array}{c}\text { Start } \\
(\mathrm{Hr})\end{array}$ & $\begin{array}{c}\text { Stop } \\
(\mathrm{Hr})\end{array}$ & $\begin{array}{c}\text { Start } \\
\text { Value }\end{array}$ & $\begin{array}{c}\text { Stop } \\
(\mathrm{Hr})\end{array}$ & Value \\
\hline 1 & 4 & $5 \%$ & 1 & 5 & $5 \%$ & 1 & 5 & $5 \%$ & 1 & 5 & $5 \%$ \\
5 & 5 & $10 \%$ & 6 & 6 & $10 \%$ & 6 & 7 & $10 \%$ & 6 & 7 & $10 \%$ \\
6 & 6 & $20 \%$ & 7 & 7 & $15 \%$ & 8 & 17 & $15 \%$ & 8 & 17 & $15 \%$ \\
7 & 7 & $40 \%$ & 8 & 14 & $25 \%$ & 18 & 20 & $10 \%$ & 18 & 20 & $10 \%$ \\
8 & 8 & $70 \%$ & 15 & 17 & $20 \%$ & 21 & 24 & $5 \%$ & 21 & 24 & $5 \%$ \\
9 & 9 & $80 \%$ & 18 & 18 & $15 \%$ & & & & & & \\
10 & 17 & $85 \%$ & 19 & 24 & $10 \%$ & & & & & & \\
18 & 18 & $80 \%$ & & & & & & & & & \\
19 & 19 & $35 \%$ & & & & & & & & & \\
20 & 24 & $10 \%$ & & & & & & & & \\
\hline
\end{tabular}


Table I-4. Equipment Heat Gain Schedule (Fraction of Full Load)

\begin{tabular}{|c|c|c|c|c|c|c|c|c|c|c|c|}
\hline \multicolumn{3}{|c|}{ Weekday } & \multicolumn{3}{|c|}{ Saturday } & \multicolumn{3}{|c|}{ Sunday } & \multicolumn{3}{|c|}{ Holiday } \\
\hline $\begin{array}{l}\text { Start } \\
\text { (Hr) }\end{array}$ & $\begin{array}{l}\text { Stop } \\
\text { (Hr) }\end{array}$ & Value & $\begin{array}{l}\text { Start } \\
(\mathrm{Hr})\end{array}$ & $\begin{array}{l}\text { Stop } \\
\text { (Hr) }\end{array}$ & Value & $\begin{array}{l}\text { Start } \\
(\mathrm{Hr})\end{array}$ & $\begin{array}{l}\text { Stop } \\
\text { (Hr) }\end{array}$ & Value & $\begin{array}{l}\text { Start } \\
(\mathrm{Hr})\end{array}$ & $\begin{array}{l}\text { Stop } \\
\text { (Hr) }\end{array}$ & Value \\
\hline 1 & 5 & $15 \%$ & 1 & 7 & $15 \%$ & 1 & 7 & $15 \%$ & 1 & 7 & $15 \%$ \\
\hline 6 & 6 & $20 \%$ & 8 & 8 & $20 \%$ & 8 & 17 & $20 \%$ & 8 & 17 & $20 \%$ \\
\hline 7 & 7 & $35 \%$ & 9 & 14 & $25 \%$ & 18 & 24 & $15 \%$ & 18 & 24 & $15 \%$ \\
\hline 8 & 8 & $60 \%$ & 15 & 17 & $20 \%$ & & & & & & \\
\hline 9 & 16 & $70 \%$ & 18 & 24 & $15 \%$ & & & & & & \\
\hline 17 & 17 & $65 \%$ & & & & & & & & & \\
\hline 18 & 18 & $45 \%$ & & & & & & & & & \\
\hline 19 & 19 & $30 \%$ & & & & & & & & & \\
\hline 20 & 21 & $20 \%$ & & & & & & & & & \\
\hline 22 & 24 & $15 \%$ & & & & & & & & & \\
\hline
\end{tabular}

Table I-5. Air-Handler Operating Schedule (Supply and Return Fans)

\begin{tabular}{|c|c|c|c|c|c|c|c|c|c|c|c|}
\hline \multicolumn{12}{|c|}{ HVAC Fan (On/Off) } \\
\hline \multicolumn{3}{|c|}{ Weekday } & \multicolumn{3}{|c|}{ Saturday } & \multicolumn{3}{|c|}{ Sunday } & \multicolumn{3}{|c|}{ Holiday } \\
\hline $\begin{array}{c}\text { Start } \\
(\mathrm{Hr})\end{array}$ & $\begin{array}{l}\text { Stop } \\
\text { (Hr) }\end{array}$ & Value & $\begin{array}{l}\text { Start } \\
(\mathrm{Hr})\end{array}$ & $\begin{array}{l}\text { Stop } \\
\text { (Hr) }\end{array}$ & Value & $\begin{array}{l}\text { Start } \\
(\mathrm{Hr})\end{array}$ & $\begin{array}{l}\text { Stop } \\
\text { (Hr) }\end{array}$ & Value & $\begin{array}{l}\text { Start } \\
(\mathrm{Hr})\end{array}$ & $\begin{array}{l}\text { Stop } \\
\text { (Hr) }\end{array}$ & Value \\
\hline 1 & 5 & Off & 1 & 5 & Off & 1 & 24 & Off & 1 & 24 & Off \\
\hline 6 & 20 & On & 6 & 15 & On & & & & & & \\
\hline 21 & 24 & Off & 16 & 24 & Off & & & & & & \\
\hline
\end{tabular}

Table I-6. Air Infiltration Schedule (Fraction of Full Infiltration Airflow)

\begin{tabular}{|c|c|c|c|c|c|c|c|c|c|c|c|}
\hline \multicolumn{12}{|c|}{ Infiltration (\%) } \\
\hline \multicolumn{3}{|c|}{ Weekday } & \multicolumn{3}{|c|}{ Saturday } & \multicolumn{3}{|c|}{ Sunday } & \multicolumn{3}{|c|}{ Holiday } \\
\hline $\begin{array}{l}\text { Start } \\
(\mathrm{Hr})\end{array}$ & $\begin{array}{l}\text { Stop } \\
\text { (Hr) }\end{array}$ & Value & $\begin{array}{l}\text { Start } \\
(\mathrm{Hr})\end{array}$ & $\begin{array}{l}\text { Stop } \\
\text { (Hr) }\end{array}$ & Value & $\begin{array}{l}\text { Start } \\
(\mathrm{Hr})\end{array}$ & $\begin{array}{l}\text { Stop } \\
\text { (Hr) }\end{array}$ & Value & $\begin{array}{l}\text { Start } \\
(\mathrm{Hr})\end{array}$ & $\begin{array}{l}\text { Stop } \\
\text { (Hr) }\end{array}$ & Value \\
\hline 1 & 5 & $100 \%$ & 1 & 5 & $100 \%$ & 1 & 24 & $100 \%$ & 1 & 24 & $100 \%$ \\
\hline 6 & 20 & $0 \%$ & 6 & 15 & $0 \%$ & & & & & & \\
\hline 21 & 24 & $100 \%$ & 16 & 24 & $100 \%$ & & & & & & \\
\hline
\end{tabular}


Table I-7. Occupancy Schedule (Fraction of Full Occupancy)

\begin{tabular}{|c|c|c|c|c|c|c|c|c|c|c|c|}
\hline \multicolumn{10}{|c|}{ People (\%) } \\
\hline \multicolumn{3}{|c|}{ Weekday } & \multicolumn{3}{|c|}{ Saturday } & \multicolumn{3}{c|}{ Sunday } & \multicolumn{3}{c|}{ Holiday } \\
\hline $\begin{array}{c}\text { Start } \\
(\mathrm{Hr})\end{array}$ & $\begin{array}{c}\text { Stop } \\
\text { (Hr) }\end{array}$ & Value & $\begin{array}{c}\text { Start } \\
(\mathrm{Hr})\end{array}$ & $\begin{array}{c}\text { Stop } \\
(\mathrm{Hr})\end{array}$ & Value & $\begin{array}{c}\text { Start } \\
(\mathrm{Hr})\end{array}$ & $\begin{array}{c}\text { Stop } \\
(\mathrm{Hr})\end{array}$ & $\begin{array}{c}\text { Value } \\
\text { (Hr) }\end{array}$ & $\begin{array}{c}\text { Stop } \\
(\mathrm{Hr})\end{array}$ & Value \\
\hline 1 & 4 & $0 \%$ & 1 & 6 & $0 \%$ & 1 & 7 & $0 \%$ & 1 & 7 & $0 \%$ \\
5 & 5 & $5 \%$ & 7 & 7 & $5 \%$ & 8 & 20 & $5 \%$ & 8 & 20 & $5 \%$ \\
6 & 6 & $10 \%$ & 8 & 17 & $15 \%$ & 21 & 24 & $0 \%$ & 21 & 24 & $0 \%$ \\
7 & 7 & $25 \%$ & 18 & 20 & $5 \%$ & & & & & & \\
8 & 11 & $65 \%$ & 21 & 24 & $0 \%$ & & & & & & \\
12 & 13 & $60 \%$ & & & & & & & & & \\
14 & 17 & $65 \%$ & & & & & & & & & \\
18 & 18 & $40 \%$ & & & & & & & & & \\
19 & 19 & $25 \%$ & & & & & & & & & \\
20 & 20 & $10 \%$ & & & & & & & & \\
21 & 24 & $5 \%$ & & & & & & & & \\
\hline
\end{tabular}




\section{APPENDIX II: REGRESSION EQUATIONS AND COEFFICIENTS}

This Appendix lists the plant energy regression equations and their coefficients that we developed to translate the intermediate floor cooling and heating coil loads (predicted by the TRNSYS air-handling system simulations) to plant energy consumption and demand (i.e., chiller electricity, cooling tower electricity, boiler electricity, and boiler fuel).

Each equation correlates the energy demand predicted by DOE-2 in a given hour to the intermediate floor part load factor for that hour (PLRC for cooling, PLRH for heating). The part load factor is defined as the hourly coil load (summed over all zones on a floor, or over all zones in the building) divided by the maximum hourly coil load over all operating hours (summed over the corresponding floor or the entire building respectively).

Tables II-1a through II-2b demonstrate that the part load ratio for a single intermediate floor can be used to represent the part load ratio for the entire building. Therefore, we used the PLR's based on a single mid-height intermediate floor to translate the coil loads to plant energy consumption and demand.

Table II-1a. Cooling Part Load Ratio Equation (PLRC)

PLRC(Building ) = A x PLRC(Intermediate Floor)

$\mathrm{R}^{2}$ Range: 1.000

\begin{tabular}{|c|c|c|}
\hline Climate Zone & Building & A \\
\hline CZ3 & 1980 & 0.994 \\
(Oakland) & 1990 & 0.995 \\
& 2005 & 0.995 \\
\hline CZ9 & 1980 & 1.005 \\
(Pasadena) & 1990 & 1.002 \\
& 2005 & 0.997 \\
\hline CZ12 & 1980 & 0.996 \\
(Sacramento) & 1990 & 0.996 \\
& 2005 & 0.997 \\
\hline
\end{tabular}

Table II-1b. Cooling Part Load Ratio - Example Values

\begin{tabular}{|c|c|}
\hline $\begin{array}{c}\text { Cooling } \\
\text { Part Load Ratio } \\
\text { (Intermediate Floor) }\end{array}$ & $\begin{array}{c}\text { Predicted Cooling } \\
\text { Part Load Ratio } \\
\text { (Whole Building) }\end{array}$ \\
\hline 0 & 0 \\
\hline 0.1 & 0.099 \\
\hline 0.5 & 0.497 \\
\hline
\end{tabular}


Table II-2a. Heating Part Load Ratio Equation (PLRH)

PLRH(Building $)=\mathrm{A} \times$ PLRH[Intermediate Floor $]+\mathrm{B} \times$ PLRH[Intermediate Floor $]^{2}$

$\mathrm{R}^{2}$ Range: 0.9999 to 1.000

\begin{tabular}{|c|c|c|c|}
\hline Climate Zone & Building & $\mathrm{A}$ & $\mathrm{B}$ \\
\hline CZ3 & 1980 & 0.984 & 0.020 \\
(Oakland) & 1990 & 0.981 & 0.020 \\
& 2005 & 0.980 & 0.026 \\
\hline CZ9 & 1980 & 0.964 & 0.037 \\
(Pasadena) & 1990 & 0.964 & 0.036 \\
& 2005 & 0.953 & 0.046 \\
\hline CZ12 & 1980 & 0.978 & 0.026 \\
(Sacramento) & 1990 & 0.977 & 0.026 \\
& 2005 & 0.971 & 0.035 \\
\hline
\end{tabular}

Table II-2b. Heating Part Load Ratio - Example Values

\begin{tabular}{|c|c|}
\hline $\begin{array}{c}\text { Heating } \\
\text { Part Load Ratio } \\
\text { (Intermediate Floor) }\end{array}$ & $\begin{array}{c}\text { Predicted Heating } \\
\text { Part Load Ratio } \\
\text { (Whole Building) }\end{array}$ \\
\hline 0 & 0 \\
\hline 0.1 & 0.099 \\
\hline 0.5 & 0.497 \\
\hline
\end{tabular}

Each cooling equation that follows in Tables II-3a, II-3b, and II-4a represents the dimensional function $\mathrm{f}(\mathrm{PLR})$ that is used in the following relation:

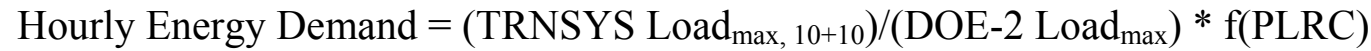

where

"TRNSYS Load $\max , 10+10 "$ is the maximum hourly cooling coil total load (sensible plus latent) determined using TRNSYS for the selected intermediate floor over all operating hours in the simulation case for the specified climate and building vintage combination, for the case with the maximum duct leakage (which requires the largest fans and coils), and

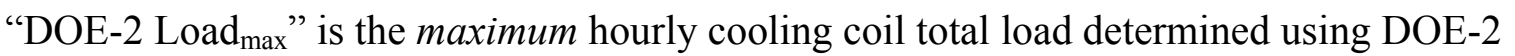
for the same floor, climate, and building vintage case.

The ratio of the TRNSYS and DOE- 2 coil loads serves as a correction to account for different equipment sizes. Specifically, we assume that plant size scales linearly with coil size. This means that an air-handling system with duct leakage (simulated by TRNSYS) that uses a cooling coil $50 \%$ larger than the one used in the associated DOE-2 simulation (with no duct leakage) will result in 50\% more chiller and cooling tower electricity being consumed at a given part load.

In the equation above, the parameter PLRC is the hourly coil part load factor determined using the hourly and maximum cooling coil loads from TRNSYS for the same floor, climate, and building vintage case: 


$$
\text { PLRC }_{\text {hour }}=\text { TRNSYS Load }_{\text {hour }} / \text { TRNSYS Load } \text { TRax }_{10+10}
$$

The $\mathrm{PLRC}_{\text {hour }}$ relation assumes that the same size fans and coils are used within a given climate and building vintage set of cases regardless of the leakage condition, and that the equipment sizes in those cases are based on the sizes required to meet the loads in the maximum leakage condition.

A similar set of relations is used with the heating equations in Tables II-5a, II-5b, II-6a, and II6b, which depend on PLRH rather than PLRC.

Table II-3a. Chiller Electricity Equation - Low PLRC

(PLRC[Intermediate Floor $]<=\sim 0.09$ )

Chiller Electricity (Building, kW) = A + B x PLRC[Intermediate Floor]

$\mathrm{R}^{2}$ Range: 0.9999 to 1.0000

\begin{tabular}{|c|c|c|c|c|}
\hline Climate Zone & Building & PLRC $<=$ & A & B \\
\hline CZ3 & 1980 & 0.089 & 9.185 & 426.201 \\
(Oakland) & 1990 & 0.089 & 8.938 & 415.787 \\
& 2005 & 0.091 & 7.310 & 335.231 \\
\hline CZ9 & 1980 & 0.086 & 12.395 & 602.760 \\
(Pasadena) & 1990 & 0.091 & 12.088 & 549.800 \\
& 2005 & 0.097 & 10.283 & 438.590 \\
\hline CZ12 & 1980 & 0.093 & 13.158 & 592.039 \\
(Sacramento) & 1990 & 0.093 & 12.684 & 566.690 \\
& 2005 & 0.095 & 9.890 & 435.552 \\
\hline
\end{tabular}

Table II-3b. Chiller Electricity Equation - High PLRC

$($ PLRC [Intermediate Floor $]>\sim 0.09$ )

Chiller Electricity $($ Building, $\mathrm{kW})=$

$\mathrm{A}+\mathrm{B} \times$ PLRC[Intermediate Floor] + C x PLRC[Intermediate Floor $]^{2}$

$\mathrm{R}^{2}$ Range: 0.9997 to 0.9998

\begin{tabular}{|c|c|c|c|c|c|}
\hline Climate Zone & Building & PLRC $>$ & A & B & C \\
\hline CZ3 & 1980 & 0.089 & 41.674 & 54.981 & 65.847 \\
(Oakland) & 1990 & 0.089 & 40.672 & 53.564 & 63.780 \\
& 2005 & 0.091 & 33.277 & 43.117 & 50.759 \\
\hline CZ9 & 1980 & 0.086 & 56.763 & 74.223 & 101.610 \\
(Pasadena) & 1990 & 0.091 & 55.621 & 66.529 & 87.714 \\
& 2005 & 0.097 & 47.259 & 52.271 & 68.044 \\
\hline CZ12 & 1980 & 0.093 & 60.760 & 69.440 & 97.390 \\
(Sacramento) & 1990 & 0.093 & 58.561 & 66.482 & 92.559 \\
& 2005 & 0.095 & 45.499 & 51.773 & 69.780 \\
\hline
\end{tabular}


Table II-3c. Chiller Electricity Consumption - Example Values

\begin{tabular}{|c|c|}
\hline $\begin{array}{c}\text { Cooling } \\
\text { Part Load Ratio } \\
\text { (Intermediate Floor) }\end{array}$ & $\begin{array}{c}\text { Predicted Chiller } \\
\text { Electricity Consumption } \\
\text { (kW) } \\
\text { (Whole Building) }\end{array}$ \\
\hline 0 & 0 \\
\hline 0.08 & 43.3 \\
\hline 0.50 & 85.6 \\
\hline
\end{tabular}

Table II-4a. Cooling Tower Electricity Equation

Cooling Tower Electricity (Building, $\mathrm{kW}$ ) =

$\mathrm{A}+\mathrm{B} \times$ PLRC[Intermediate Floor] $+\mathrm{C} \times$ PLRC[Intermediate Floor ${ }^{2}+$

D x PLRC[Intermediate Floor $]^{3}+$ E x PLRC[Intermediate Floor $]^{4}$

$\mathrm{R}^{2}$ Range: 0.9338 to 0.9997

\begin{tabular}{|c|c|c|c|c|c|c|}
\hline Climate Zone & Building & A & B & C & D & E \\
\hline CZ3 & 1980 & 14.614 & 1.591 & 7.699 & -9.158 & 4.965 \\
(Oakland) & 1990 & 14.267 & 1.514 & 7.547 & -9.048 & 4.907 \\
& 2005 & 11.669 & 1.252 & 6.139 & -7.374 & 4.011 \\
\hline CZ9 & 1980 & 19.859 & 0.208 & 27.112 & -62.199 & 51.365 \\
(Pasadena) & 1990 & 19.390 & 0.296 & 22.953 & -50.140 & 38.975 \\
& 2005 & 16.325 & 3.979 & -2.383 & 0.365 & 6.147 \\
\hline CZ12 & 1980 & 20.955 & 2.906 & 7.532 & -15.125 & 15.643 \\
(Sacramento) & 1990 & 20.198 & 2.783 & 7.468 & -15.694 & 15.968 \\
& 2005 & 15.724 & 3.131 & 0.236 & -0.982 & 5.966 \\
\hline
\end{tabular}

Table II-4b. Cooling Tower Electricity Consumption - Example Values

\begin{tabular}{|c|c|}
\hline $\begin{array}{c}\text { Cooling } \\
\text { Part Load Ratio } \\
\text { (Intermediate Floor) }\end{array}$ & $\begin{array}{c}\text { Predicted Cooling Tower } \\
\text { Electricity Consumption } \\
(\mathrm{kW}) \\
\text { (Whole Building) }\end{array}$ \\
\hline 0 & 0.000 \\
\hline 0.5 & 16.500 \\
\hline 0.8 & 18.159 \\
\hline
\end{tabular}


Table II-5a. Boiler Electricity Equation - Low PLRH

(PLRH[Intermediate Floor] $<=\sim 0.40$ )

Boiler Electricity $($ Building, $\mathrm{kW})=$

$\mathrm{A}+\mathrm{B} \times \mathrm{PLRH}[\text { Intermediate Floor] }+\mathrm{C} \text { x PLRH[Intermediate Floor }]^{2}$

$\mathrm{R}^{2}$ Range: 0.9924 to 0.9977

\begin{tabular}{|c|c|c|c|c|c|}
\hline Climate Zone & Building & PLRH $<=$ & A & B & C \\
\hline CZ3 & 1980 & 0.387 & 0.530 & 57.568 & 2.401 \\
(Oakland) & 1990 & 0.370 & 0.495 & 56.688 & 2.303 \\
& 2005 & 0.410 & 0.402 & 41.619 & 1.344 \\
\hline CZ9 & 1980 & 0.310 & 0.392 & 54.011 & 7.356 \\
(Pasadena) & 1990 & 0.315 & 0.371 & 52.832 & 4.766 \\
& 2005 & 0.348 & 0.322 & 34.293 & 4.139 \\
\hline CZ12 & 1980 & 0.357 & 0.661 & 74.052 & 8.906 \\
(Sacramento) & 1990 & 0.335 & 0.583 & 72.013 & 5.284 \\
& 2005 & 0.345 & 0.380 & 43.743 & 5.713 \\
\hline
\end{tabular}

Table II-5b. Boiler Electricity Equation - High PLRH

(PLRH[Intermediate Floor] > 0.40)

Boiler Electricity (Building, $\mathrm{kW})=\mathrm{A}$

$\mathrm{R}^{2}$ Range: 1.000

\begin{tabular}{|c|c|c|c|}
\hline Climate Zone & Building & PLRH $>$ & A \\
\hline CZ3 & 1980 & 0.387 & 23.195 \\
(Oakland) & 1990 & 0.370 & 21.731 \\
& 2005 & 0.410 & 17.797 \\
\hline CZ9 & 1980 & 0.310 & 17.966 \\
(Pasadena) & 1990 & 0.315 & 17.478 \\
& 2005 & 0.348 & 12.747 \\
\hline CZ12 & 1980 & 0.357 & 28.270 \\
(Sacramento) & 1990 & 0.335 & 25.661 \\
& 2005 & 0.345 & 16.149 \\
\hline
\end{tabular}

Table II-5c. Boiler Electricity Consumption - Example Values

\begin{tabular}{|c|c|}
\hline $\begin{array}{c}\text { Heating } \\
\text { Part Load Ratio } \\
\text { (Intermediate Floor) }\end{array}$ & $\begin{array}{c}\text { Predicted Boiler } \\
\text { Electricity Consumption } \\
(\mathrm{kW}) \\
\text { (Whole Building) }\end{array}$ \\
\hline 0 & 0.0 \\
\hline 0.2 & 12.1 \\
\hline 0.5 & 23.2 \\
\hline
\end{tabular}


Table II-6a. Boiler Fuel Equation - Low PLRH

(PLRH[Intermediate Floor] $<=\sim 0.40$ )

Boiler Fuel (Building, Btu/h) =

$\mathrm{A}+\mathrm{B} \times \mathrm{PLRH}[\text { Intermediate Floor] }+\mathrm{C} \text { x PLRH[Intermediate Floor }]^{2}$

$\mathrm{R}^{2}$ Range: 0.9990 to 0.9997

\begin{tabular}{|c|c|c|c|c|c|}
\hline Climate Zone & Building & PLRH $<=$ & A & B & C \\
\hline CZ3 & 1980 & 0.387 & 33,611 & $3,648,544$ & 152,214 \\
(Oakland) & 1990 & 0.370 & 31,341 & $3,592,824$ & 145,799 \\
& 2005 & 0.410 & 25,463 & $2,637,797$ & 84,964 \\
\hline CZ9 & 1980 & 0.310 & 24,834 & $3,423,115$ & 466,319 \\
(Pasadena) & 1990 & 0.315 & 23,536 & $3,348,410$ & 301,913 \\
& 2005 & 0.348 & 20,388 & $2,173,399$ & 262,440 \\
\hline CZ12 & 1980 & 0.357 & 41,880 & $4,693,275$ & 564,484 \\
(Sacramento) & 1990 & 0.335 & 37,007 & $4,563,984$ & 335,031 \\
& 2005 & 0.345 & 24,089 & $2,772,405$ & 361,904 \\
\hline
\end{tabular}

Table II-6b. Boiler Fuel Equation - High PLRH

(PLRH[Intermediate Floor] $>\sim 0.40$ )

Boiler Fuel (Building, Btu/h) = A + B x PLRH[Intermediate Floor]

$\mathrm{R}^{2}$ Range: 0.9984 to 0.9996

\begin{tabular}{|c|c|c|c|c|}
\hline Climate Zone & Building & PLRH $>$ & $\mathrm{A}$ & $\mathrm{B}$ \\
\hline CZ3 & 1980 & 0.387 & 447,637 & $2,651,439$ \\
(Oakland) & 1990 & 0.370 & 423,385 & $2,603,255$ \\
& 2005 & 0.410 & 333,343 & $1,934,786$ \\
\hline CZ9 & 1980 & 0.310 & 365,870 & $2,538,821$ \\
(Pasadena) & 1990 & 0.315 & 356,207 & $2,452,285$ \\
& 2005 & 0.348 & 244,708 & $1,646,832$ \\
\hline CZ12 & 1980 & 0.357 & 562,719 & $3,462,940$ \\
(Sacramento) & 1990 & 0.335 & 516,927 & $3,318,081$ \\
& 2005 & 0.345 & 319,932 & $2,068,909$ \\
\hline
\end{tabular}

Table II-6c. Boiler Fuel Consumption - Example Values

\begin{tabular}{|c|c|}
\hline $\begin{array}{c}\text { Heating } \\
\text { Part Load Ratio } \\
\text { (Intermediate Floor) }\end{array}$ & $\begin{array}{c}\text { Predicted Boiler } \\
\text { Fuel Consumption } \\
\text { (Btu/h) } \\
\text { (Whole Building) }\end{array}$ \\
\hline 0 & 0 \\
\hline 0.2 & 769,400 \\
\hline 0.5 & $1,773,400$ \\
\hline
\end{tabular}


APPENDIX III: ENERGY PERFORMANCE IMPACTS

Table III-1. Leakage Impacts on Annual Energy Use

\begin{tabular}{|c|c|c|c|c|c|c|c|c|c|c|c|c|c|c|}
\hline \multirow{3}{*}{\multicolumn{2}{|c|}{ CZ Vintage }} & \multicolumn{13}{|c|}{ Annual Site Energy Use [MWh] } \\
\hline & & $\begin{array}{c}\text { Supply } \\
\text { Fan }\end{array}$ & \multirow[t]{2}{*}{$\begin{array}{c}\text { Return } \\
\text { Fan } \\
\end{array}$} & \multirow[t]{2}{*}{$\begin{array}{l}\text { Both } \\
\text { Fans } \\
\end{array}$} & \multirow[t]{2}{*}{$\begin{array}{c}\text { Cooling } \\
\text { Coil }\end{array}$} & \multirow{2}{*}{$\begin{array}{r}\begin{array}{c}\text { Reheat } \\
\text { Coils }\end{array} \\
10+\end{array}$} & \multirow{2}{*}{$\begin{array}{c}\text { Chiller } \\
\text { Electricity } \\
10 \text { (Upstre }\end{array}$} & \multirow{2}{*}{$\begin{array}{c}\text { Tower } \\
\text { Electricity } \\
\mathbf{m}+\text { Down }\end{array}$} & \multirow{2}{*}{$\begin{array}{l}\text { Cooling } \\
\text { Energy } \\
\text { stream) L }\end{array}$} & \multirow{2}{*}{\begin{tabular}{|c|c} 
Boiler \\
Electricity \\
-eaks
\end{tabular}} & $\begin{array}{l}\text { Boiler } \\
\text { Fuel }\end{array}$ & $\begin{array}{l}\text { Heating } \\
\text { Energy }\end{array}$ & \begin{tabular}{|c|} 
Total \\
Electricity
\end{tabular} & \begin{tabular}{|c|} 
Total \\
Energy \\
\end{tabular} \\
\hline & & & & & & & & & & & & & & \\
\hline & Old & 141 & 49 & 190 & 1,201 & 232 & 297 & 77 & $\overline{374}$ & 13 & 257 & 270 & 578 & 835 \\
\hline 3 & New & 141 & 49 & 190 & 1,194 & 204 & 292 & 75 & 367 & 12 & 236 & 249 & 570 & 806 \\
\hline & T24 & 121 & 43 & 164 & 1,041 & 146 & 255 & 67 & 322 & 8 & 154 & 162 & 494 & 648 \\
\hline & Old & 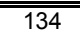 & 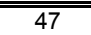 & $\overline{181}$ & 2,572 & $\overline{323}$ & $\overline{531}$ & 104 & 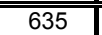 & $\overline{19}$ & 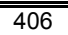 & $\overline{425}$ & $\overline{835}$ & 1,241 \\
\hline 9 & New & 133 & 47 & 179 & 2,626 & 421 & 513 & 103 & 616 & 24 & 524 & 548 & 819 & 1,343 \\
\hline & T24 & 109 & 39 & 148 & 2,120 & 175 & 415 & 91 & 505 & 9 & 200 & 209 & 663 & 862 \\
\hline & "Old & 154 & $\overline{54}$ & 208 & $\overline{2,162}$ & $\overline{385}$ & 40 & 94 & $\overline{532}$ & 23 & 2441 & $4 \overline{464}$ & $\overline{c 763}$ & 1,204 \\
\hline 12 & New & 152 & 53 & 205 & 2,101 & 332 & 423 & 90 & 513 & 20 & 400 & 420 & 739 & 1,139 \\
\hline & T24 & 118 & 42 & 160 & 1,737 & 184 & 350 & 77 & 427 & 11 & 215 & 226 & 597 & 813 \\
\hline & & & & & & $7.5+$ & 7.5 (Upstre & $\mathrm{am}+$ Dowr & stream) & Leaks & & & & \\
\hline & Old & 122 & 43 & 165 & 1,109 & 235 & 285 & 76 & 361 & 14 & 261 & 275 & $\overline{540}$ & 801 \\
\hline 3 & New & 122 & 43 & 165 & 1,107 & 208 & 281 & 75 & 355 & 13 & 241 & 254 & 532 & 773 \\
\hline & T24 & 105 & 37 & 142 & 959 & 148 & 245 & 66 & 311 & 8 & 156 & 164 & 461 & 616 \\
\hline & "Old & 1117 & 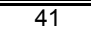 & 159 & 2,466 & 334 & 516 & 103 & 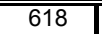 & $\overline{19}$ & $4 \quad 421$ & 4440 & 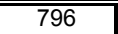 & 1,217 \\
\hline 9 & New & 117 & 41 & 158 & 2,495 & 437 & 495 & 102 & 597 & 25 & 543 & 568 & 780 & 1,323 \\
\hline & T24 & 95 & 34 & 129 & 2,026 & 180 & 403 & 90 & 493 & 10 & 206 & 216 & 632 & 837 \\
\hline & Old & 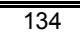 & $\overline{477}$ & 181 & $\begin{array}{l}2,077 \\
\end{array}$ & $\overline{389}$ & $\overline{c 427}$ & 93 & $\overline{520}$ & 23 & $=2446$ & $\overline{4469}$ & $\overline{724}$ & 1,169 \\
\hline 12 & New & 132 & 46 & 178 & 2,019 & 336 & 412 & 90 & 502 & 21 & 405 & 425 & 701 & 1,105 \\
\hline & T24 & 102 & 36 & 139 & 1,667 & 186 & 340 & 76 & 417 & 11 & 218 & 229 & 566 & 784 \\
\hline & & & & & & $10+$ & 2.5 (Upstre & am + Down & stream) L & -eaks & & & & \\
\hline & Old & 120 & 42 & 162 & 1,096 & 242 & 283 & 76 & 359 & 14 & 269 & 283 & 535 & 804 \\
\hline 3 & New & 119 & 42 & 161 & 1,091 & 216 & 279 & 75 & 353 & 13 & 250 & 263 & 528 & 778 \\
\hline & T24 & 102 & 36 & 138 & 943 & 152 & 243 & 66 & 309 & 8 & 160 & 168 & 455 & 615 \\
\hline & "Old & 120 & 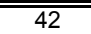 & 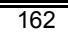 & $\overline{2,492}$ & 359 & $\overline{520}$ & 103 & 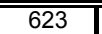 & $\overline{21}$ & $4 \quad 452$ & 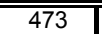 & $\overline{805}$ & 1,257 \\
\hline 9 & New & 121 & 43 & 164 & 2,534 & 470 & 501 & 102 & 603 & 27 & 583 & 610 & 793 & 1,376 \\
\hline & T24 & 95 & 34 & 129 & 2,031 & 191 & 404 & 90 & 494 & 10 & 219 & 229 & 633 & 852 \\
\hline & Old & 132 & 47 & 179 & 2,070 & 396 & 4426 & $\overline{93}$ & $\overline{518}$ & $\overline{24}$ & $4 \quad 454$ & 448 & $\overline{721}$ & 1,176 \\
\hline 12 & New & 131 & 46 & 177 & 2,010 & 344 & 410 & 90 & 500 & 21 & 415 & 436 & 698 & 1,113 \\
\hline & T24 & 101 & 36 & 136 & 1,656 & 190 & 339 & 76 & 415 & 11 & 224 & 235 & 563 & 787 \\
\hline & & & & & & $2.5+$ & 10 (Upstre & $\mathrm{am}+$ Down & stream) L & -eaks & & & & \\
\hline & Old & 110 & 39 & 148 & 1,044 & 232 & 276 & 76 & 352 & 13 & 257 & 270 & 513 & 770 \\
\hline 3 & New & 109 & 38 & 148 & 1,042 & 204 & 272 & 74 & 346 & 12 & 236 & 249 & 506 & 743 \\
\hline & T24 & 94 & 33 & 127 & 904 & 146 & 237 & 66 & 303 & 8 & 154 & 162 & 438 & 592 \\
\hline & Old & 102 & $\overline{c 36}$ & 138 & 2,347 & $\overline{323}$ & 4998 & 101 & $\overline{5999}$ & $\overline{19}$ & $=406$ & 425 & $\overline{756}$ & 1,162 \\
\hline 9 & New & 102 & 36 & 137 & 2,365 & 421 & 478 & 101 & 579 & 24 & 524 & 548 & 740 & 1,264 \\
\hline & T24 & 84 & 30 & 113 & 1,940 & 175 & 392 & 89 & 482 & 9 & 200 & 209 & 604 & 804 \\
\hline 12 & "Old & 1119 & $\overline{42}$ & $\overline{161}$ & $\begin{array}{l}2,010 \\
\end{array}$ & $\overline{385}$ & 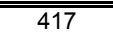 & $\overline{93}$ & $\overline{510}$ & $\overline{23}$ & $=4441$ & $\overline{4664}$ & $\overline{6993}$ & 1,135 \\
\hline 12 & New & 117 & 41 & 159 & 1,955 & 332 & 403 & 90 & 492 & 20 & 400 & 420 & 671 & 1,071 \\
\hline & T24 & 91 & 32 & 124 & 1,615 & 184 & 333 & 76 & 409 & 11 & 215 & 226 & 543 & 759 \\
\hline & & & & & & & (Upstrea & $\overline{n+\text { Downs }}$ & tream) Le & aks & & & & \\
\hline & Old & 107 & 38 & 144 & 1,028 & 239 & 274 & 76 & 350 & $\overline{14}$ & 265 & 279 & 508 & 773 \\
\hline 3 & New & 107 & 38 & 144 & 1,026 & 212 & 270 & 74 & 344 & 13 & 246 & 259 & 501 & 747 \\
\hline & T24 & 91 & 32 & 124 & 885 & 150 & 235 & 66 & 301 & 8 & 158 & 166 & 433 & 591 \\
\hline & Old & 104 & 37 & 1414 & $2,2,369$ & $\overline{346}$ & $\overline{501}$ & $\overline{101}$ & 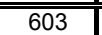 & $\overline{20}$ & $4 \quad 436$ & $\overline{c 456}$ & $\overline{764}$ & 1,200 \\
\hline 9 & New & 105 & 37 & 142 & 2,401 & 453 & 483 & 101 & 584 & 26 & 563 & 589 & 751 & 1,314 \\
\hline & T24 & 84 & 30 & 113 & 1,942 & 185 & 392 & 89 & 482 & 10 & 212 & 222 & 605 & 817 \\
\hline & "Old & "117 & $\overline{441}$ & 158 & $=2,001$ & 392 & (416 & $\overline{93}$ & $\overline{509}$ & $\overline{23}$ & 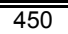 & $\overline{4473}$ & $\overline{6691}$ & 1,141 \\
\hline 12 & New & 116 & 41 & 156 & 1,945 & 340 & 401 & 89 & 491 & 21 & 410 & 431 & 668 & 1,078 \\
\hline & T24 & 89 & 32 & 121 & 1,603 & 188 & 332 & 76 & 408 & 11 & 221 & 232 & 540 & 761 \\
\hline & & & & & & $2.5+$ & .5 (Upstre & $\mathrm{am}+$ Dowr & istream) & Leaks & & & & \\
\hline & Old & $\overline{94}$ & $\overline{33}$ & 128 & 953 & $\overline{242}$ & 264 & 76 & 339 & 14 & 269 & 283 & 481 & 750 \\
\hline 3 & New & 94 & 33 & 127 & 952 & 216 & 260 & 74 & 334 & 13 & 250 & 264 & 474 & 725 \\
\hline & T24 & 80 & 29 & 109 & 820 & 152 & 226 & 66 & 292 & 8 & 160 & 168 & 409 & 569 \\
\hline & Old & $\overline{993}$ & $\overline{33}$ & $\overline{c 126}$ & 2,282 & 359 & $4 \overline{489}$ & 101 & $\overline{589}$ & $\overline{21}$ & $4 \quad 452$ & $\overline{4473}$ & $\overline{7377}$ & 1,189 \\
\hline 9 & New & 95 & 34 & 128 & 2,314 & 470 & 472 & 101 & 572 & 27 & 583 & 610 & 727 & 1,310 \\
\hline & T24 & 74 & 26 & 101 & 1,866 & 191 & 383 & 89 & 472 & 10 & 219 & 229 & 583 & 802 \\
\hline & OId & $\bar{~} 104$ & 37 & $\overline{1440}$ & $\begin{array}{l}1,933 \\
\end{array}$ & $\overline{396}$ & $\overline{4066}$ & $\overline{92}$ & $\overline{4499}$ & $\overline{24}$ & $=4455$ & $\begin{array}{l}478 \\
\end{array}$ & $\overline{c 663}$ & \begin{tabular}{|c|}
1,117 \\
\end{tabular} \\
\hline 12 & New & 102 & 36 & 139 & 1,878 & 344 & 392 & 89 & 481 & 21 & 415 & 437 & 641 & 1,056 \\
\hline & T24 & 79 & 28 & 107 & 1,546 & 190 & 324 & 76 & 400 & 11 & 224 & 235 & 518 & 742 \\
\hline
\end{tabular}


Table III-2a. Fractional Impacts of Leakage on Energy Uses

\begin{tabular}{|c|c|c|c|c|c|c|c|c|c|c|c|c|c|c|}
\hline & \multicolumn{3}{|c|}{ Total Energy Use [\%] } & \multicolumn{3}{|c|}{ Electrical Use [\%] } & \multicolumn{7}{|c|}{ Energy Increase Due to Leakage [\%] } \\
\hline & & $\begin{array}{l}\text { Both } \\
\text { Fans }\end{array}$ & $\begin{array}{l}\text { Cooling } \\
\text { Energy }\end{array}$ & $\begin{array}{l}\text { Heating } \\
\text { Energy }\end{array}$ & $\begin{array}{l}\text { Both } \\
\text { Fans }\end{array}$ & $\begin{array}{l}\text { Cooling } \\
\text { Energy }\end{array}$ & $\begin{array}{l}\text { Heating } \\
\text { Energy }\end{array}$ & $\begin{array}{l}\text { Both } \\
\text { Fans }\end{array}$ & $\begin{array}{c}\text { Cooling } \\
\text { Coil }\end{array}$ & $\begin{array}{c}\text { Reheat } \\
\text { Coils }\end{array}$ & \multirow[t]{2}{*}{$\begin{array}{l}\text { Cooling } \\
\text { Energy }\end{array}$} & \multirow[t]{2}{*}{$\begin{array}{l}\text { Heating } \\
\text { Energy }\end{array}$} & \multirow[t]{2}{*}{$\begin{array}{c}\text { Total } \\
\text { Electricity }\end{array}$} & $\begin{array}{l}\text { Total } \\
\text { Energy }\end{array}$ \\
\hline & & \multicolumn{10}{|c|}{$10+10$ (Upstream + Downstream) Leaks } & & & \\
\hline \multirow{3}{*}{3} & Old & 23 & 45 & 32 & $\overline{33}$ & 65 & 2 & 49 & 26 & $\overline{-4}$ & 10 & -5 & 20 & 11 \\
\hline & New & 24 & 46 & 31 & 33 & 65 & 2 & 49 & 25 & -5 & 10 & -6 & 20 & 11 \\
\hline & T24 & 25 & 50 & 25 & 33 & 65 & 2 & 50 & 27 & -4 & 10 & -4 & 21 & 14 \\
\hline \multirow{3}{*}{9} & Old & 15 & $\overline{51}$ & $\overline{34}$ & 22 & 76 & 2 & 43 & $\overline{13}$ & -10 & 8 & $\overline{-10}$ & 13 & $\overline{4}$ \\
\hline & New & 13 & 46 & 41 & 22 & 75 & 3 & 40 & 13 & -10 & 8 & -10 & 13 & 2 \\
\hline & T24 & 17 & 59 & 24 & 22 & 76 & 1 & 47 & 14 & -9 & 7 & -9 & 14 & 8 \\
\hline \multirow{7}{*}{12} & Old & 17 & 44 & 39 & 27 & 70 & 3 & 48 & 12 & -3 & 7 & -3 & 15 & 8 \\
\hline & New & 18 & 45 & 37 & 28 & 69 & 3 & 48 & 12 & -3 & 7 & -4 & 15 & 8 \\
\hline & T24 & 20 & 53 & 28 & 27 & 71 & 2 & 50 & 12 & -3 & 7 & -4 & 15 & 10 \\
\hline & Avg & 19 & 49 & 32 & 27 & 70 & 2 & 47 & 17 & -6 & 8 & -6 & 16 & 8 \\
\hline & Min & 13 & 44 & 24 & 22 & 65 & 1 & 40 & 12 & -10 & 7 & -10 & 13 & 2 \\
\hline & Max & 25 & 59 & 41 & 33 & 76 & 3 & 50 & 27 & -3 & 10 & -3 & 21 & 14 \\
\hline & & \multicolumn{13}{|c|}{$7.5+7.5$ (Upstream + Downstream) Leaks } \\
\hline & Old & 21 & 45 & 34 & 31 & 67 & 3 & 29 & 16 & -3 & 6 & -3 & 12 & 7 \\
\hline 3 & New & 21 & 46 & 33 & 31 & 67 & 2 & 29 & 16 & -4 & 6 & -4 & 12 & 7 \\
\hline & T24 & 23 & 50 & 27 & 31 & 67 & 2 & 30 & 17 & -2 & 6 & -3 & 13 & 8 \\
\hline & Old & 13 & $\overline{51}$ & 36 & 20 & $\overline{78}$ & 2 & 25 & $\overline{\overline{8}}$ & $\overline{-\overline{-7}}$ & $\overline{\overline{5}}$ & $\overline{-17}$ & 8 & $\overline{2}$ \\
\hline 9 & New & 12 & 45 & 43 & 20 & 77 & 3 & 23 & 8 & -7 & 4 & -7 & 7 & 1 \\
\hline & T24 & 15 & 59 & 26 & 20 & 78 & 2 & 28 & 9 & -6 & 4 & -6 & 8 & 4 \\
\hline & "Oाd & 15 & $\overline{444}$ & $\overline{40}$ & $\overline{25}$ & $\overline{\overline{72}}$ & $\overline{\overline{3}}$ & $\overline{29}$ & $\overline{7}$ & $\overline{-\overline{-2}}$ & $\overline{\overline{4}}$ & $\overline{-2}$ & $\overline{9}$ & $\overline{5}$ \\
\hline 12 & New & 16 & 45 & 38 & 25 & 72 & 3 & 29 & 7 & -2 & 4 & -3 & 9 & 5 \\
\hline & T24 & 18 & 53 & 29 & 24 & 74 & 2 & 30 & 8 & -2 & 4 & -3 & 9 & 6 \\
\hline & Avg & 17 & 49 & 34 & 25 & 72 & 2 & 28 & 11 & -4 & 5 & -4 & 10 & 5 \\
\hline & Min & 12 & 44 & 26 & 20 & 67 & 2 & 23 & 7 & -7 & 4 & -7 & 7 & 1 \\
\hline & Max & 23 & 59 & 43 & 31 & 78 & 3 & 30 & 17 & -2 & 6 & -2 & 13 & 8 \\
\hline & & & & & & $10+2$ & 5 (Upstre & $a m+$ & Downstre & am) Lea & & & & \\
\hline & Old & 20 & 45 & 35 & 30 & 67 & $\overline{3}$ & 27 & 15 & $\overline{0}$ & 6 & $\overline{0}$ & 11 & 7 \\
\hline 3 & New & 21 & 45 & 34 & 31 & 67 & 2 & 27 & 15 & 0 & 6 & 0 & 11 & 7 \\
\hline & T24 & 22 & 50 & 27 & 30 & 68 & 2 & 27 & 15 & 0 & 6 & 0 & 11 & 8 \\
\hline & Old & 13 & 50 & 38 & 20 & 77 & $\overline{3}$ & 28 & $\overline{9}$ & $\overline{0}$ & $\overline{6}$ & $\overline{0}$ & $\overline{9}$ & 6 \\
\hline 9 & New & 12 & 44 & 44 & 21 & 76 & 3 & 28 & 10 & 0 & 5 & 0 & 9 & 5 \\
\hline & T24 & 15 & 58 & 27 & 20 & 78 & 2 & 28 & 9 & 0 & 5 & 0 & 9 & 6 \\
\hline & Old & 15 & 44 & 41 & 25 & 72 & $\overline{3}$ & 28 & $\overline{7}$ & $\overline{0}$ & 4 & $\overline{0}$ & $\overline{9}$ & 5 \\
\hline 12 & New & 16 & 45 & 39 & 25 & 72 & 3 & 27 & 7 & 0 & 4 & 0 & 9 & 5 \\
\hline & T24 & 17 & 53 & 30 & 24 & 74 & 2 & 28 & 7 & 0 & 4 & 0 & 9 & 6 \\
\hline & Avg & 17 & 48 & 35 & 25 & 72 & 3 & 27 & 10 & $\overline{0}$ & 5 & 0 & 10 & 6 \\
\hline & Min & 12 & 44 & 27 & 20 & 67 & 2 & 27 & 7 & 0 & 4 & 0 & 9 & 5 \\
\hline & Max & 22 & 58 & 44 & 31 & 78 & 3 & 28 & 15 & 0 & 6 & 0 & 11 & 8 \\
\hline
\end{tabular}


Table III-2b. Fractional Impacts of Leakage on Energy Uses

\begin{tabular}{|c|c|c|c|c|c|c|c|c|c|c|c|c|c|c|}
\hline & \multicolumn{3}{|c|}{ Total Energy Use [\%] } & \multicolumn{3}{|c|}{ Electrical Use [\%] } & \multicolumn{7}{|c|}{ Energy Increase Due to Leakage [\%] } \\
\hline & & \multirow{2}{*}{$\begin{array}{l}\text { Both } \\
\text { Fans }\end{array}$} & \multirow{2}{*}{$\begin{array}{l}\text { Cooling } \\
\text { Energy }\end{array}$} & \multirow{2}{*}{$\begin{array}{l}\text { Heating } \\
\text { Energy }\end{array}$} & \multirow{2}{*}{$\begin{array}{l}\text { Both } \\
\text { Fans }\end{array}$} & \multirow{2}{*}{$\begin{array}{l}\text { Cooling } \\
\text { Energy }\end{array}$} & \multirow{2}{*}{$\begin{array}{l}\text { Heating } \\
\text { Energy }\end{array}$} & \multirow{2}{*}{$\begin{array}{l}\text { Both } \\
\text { Fans } \\
\end{array}$} & \multirow{2}{*}{$\begin{array}{c}\text { Cooling } \\
\text { Coil }\end{array}$} & \multirow{2}{*}{$\begin{array}{l}\text { Reheat } \\
\text { Coils }\end{array}$} & \multirow{2}{*}{$\begin{array}{l}\text { Cooling } \\
\text { Energy }\end{array}$} & \multirow{2}{*}{$\begin{array}{l}\text { Heating } \\
\text { Energy }\end{array}$} & \multirow{2}{*}{$\begin{array}{c}\text { Total } \\
\text { Electricity }\end{array}$} & \multirow{2}{*}{$\begin{array}{c}\text { Total } \\
\text { Energy }\end{array}$} \\
\hline $\mathrm{CZ}$ & Vintage & & & & & & & & & & & & & \\
\hline & & \multicolumn{13}{|c|}{$2.5+10$ (Upstream + Downstream) Leaks } \\
\hline \multirow{3}{*}{3} & Old & 19 & 46 & 35 & 29 & 69 & 3 & 16 & 10 & -4 & 4 & -5 & 7 & 3 \\
\hline & New & 20 & 47 & 34 & 29 & 68 & 2 & 16 & 9 & -5 & 4 & -6 & 7 & 3 \\
\hline & $\mathrm{T} 24$ & 22 & 51 & 27 & 29 & 69 & 2 & 17 & 10 & -4 & 4 & -4 & 7 & 4 \\
\hline \multirow{3}{*}{9} & "Old & $\overline{c 12}$ & $\overline{52}$ & 37 & $\overline{\overline{18}}$ & 79 & $\overline{\overline{2}}$ & $\overline{\overline{9}}$ & 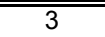 & -10 & $\overline{2}$ & -10 & 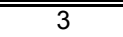 & $\overline{-2}$ \\
\hline & New & 11 & 46 & 43 & 19 & 78 & 3 & 7 & 2 & -10 & 1 & -10 & 2 & -4 \\
\hline & T24 & 14 & 60 & 26 & 19 & 80 & 2 & 12 & 4 & -9 & 2 & -9 & 4 & 0 \\
\hline \multirow{7}{*}{12} & "Old & $\overline{14}$ & 45 & $\overline{441}$ & 23 & $\overline{74}$ & $\overline{3}$ & $\overline{14}$ & 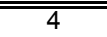 & -3 & $\overline{2}$ & -3 & $\overline{55}$ & 2 \\
\hline & New & 15 & 46 & 39 & 24 & 73 & 3 & 15 & 4 & -3 & 2 & -4 & 5 & 1 \\
\hline & T24 & 16 & 54 & 30 & 23 & 75 & 2 & 16 & 4 & -3 & 2 & -4 & 5 & 2 \\
\hline & Avg & 16 & 50 & 35 & 24 & 74 & 2 & 14 & 6 & -6 & 3 & -6 & 5 & 1 \\
\hline & Min & 11 & 45 & 26 & 18 & 68 & 2 & 7 & 2 & -10 & 1 & -10 & 2 & -4 \\
\hline & Max & 22 & 60 & 43 & 29 & 80 & 3 & 17 & 10 & -3 & 4 & -3 & 7 & 4 \\
\hline & & $5+5(U$ & ostream & + Downs & tream & Leaks & & & & & & & & \\
\hline & Old & 19 & 45 & 36 & 28 & 69 & 3 & 13 & 8 & -1 & 3 & -2 & 6 & 3 \\
\hline 3 & New & 19 & 46 & 35 & 29 & 69 & 3 & 13 & 8 & -2 & 3 & -2 & 6 & 3 \\
\hline & T24 & 21 & 51 & 28 & 29 & 70 & 2 & 14 & 8 & -1 & 3 & -1 & 6 & 4 \\
\hline & "Old & 12 & 50 & 38 & 18 & 79 & 3 & 11 & 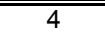 & -3 & 2 & -4 & 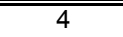 & 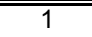 \\
\hline 9 & New & 11 & 44 & 45 & 19 & 78 & 3 & 10 & 4 & -4 & 2 & -3 & 3 & 0 \\
\hline & T24 & 14 & 59 & 27 & 19 & 80 & 2 & 12 & 4 & -3 & 2 & -3 & 4 & 2 \\
\hline & Old & 14 & 45 & 41 & 23 & 74 & 3 & 13 & $\overline{44}$ & -1 & 2 & -1 & $\overline{44}$ & 2 \\
\hline 12 & New & 15 & 46 & 40 & 23 & 73 & 3 & 13 & 4 & -1 & 2 & -1 & 4 & 2 \\
\hline & T24 & 16 & 54 & 30 & 22 & 76 & 2 & 13 & 4 & -1 & 2 & -1 & 4 & 3 \\
\hline & Avg & 16 & 49 & 36 & 23 & 74 & 3 & 13 & 5 & -2 & 2 & -2 & 5 & 2 \\
\hline & Min & 11 & 44 & 27 & 18 & 69 & 2 & 10 & 4 & -4 & 2 & -4 & 3 & 0 \\
\hline & Max & 21 & 59 & 45 & 29 & 80 & 3 & 14 & 8 & -1 & 3 & -1 & 6 & 4 \\
\hline & & & & & & $2.5+2$ & 5 (Upstre & am + & Downstr & eam) Lea & ks & & & \\
\hline & Old & 17 & 45 & 38 & 27 & 71 & 3 & & & & & & & \\
\hline 3 & New & 18 & 46 & 36 & 27 & 70 & 3 & & & & & & & \\
\hline & $\mathrm{T} 24$ & 19 & 51 & 30 & 27 & 71 & 2 & & & & & & & \\
\hline & Old & 11 & 50 & 40 & 17 & 80 & 3 & & & & & & & \\
\hline 9 & New & 10 & 44 & 47 & 18 & 79 & 4 & & & & & & & \\
\hline & T24 & 13 & 59 & 29 & 17 & 81 & 2 & & & & & & & \\
\hline & Old & 13 & 45 & 43 & 21 & 75 & $\overline{4}$ & & & & & & & \\
\hline 12 & New & 13 & 46 & 41 & 22 & 75 & 3 & & & & & & & \\
\hline & T24 & 14 & 54 & 32 & 21 & 77 & 2 & & & & & & & \\
\hline & Avg & 14 & 49 & 37 & 22 & 75 & 3 & & & & & & & \\
\hline & Min & 10 & 44 & 29 & 17 & 70 & 2 & & & & & & & \\
\hline & Max & 19 & 59 & 47 & 27 & 81 & 4 & & & & & & & \\
\hline
\end{tabular}




\section{APPENDIX IV: EQUIPMENT SIZING IMPACTS}

Table IV-1a. Leakage Impacts on Equipment Sizing

\begin{tabular}{|c|c|c|c|c|c|c|c|c|c|c|c|c|}
\hline \multirow{2}{*}{\multicolumn{2}{|c|}{ CZ Vintage }} & \multicolumn{3}{|c|}{ Maximum Airflows [scfm] } & \multicolumn{2}{|c|}{ Zone Part Load Flow Ratio } & \multicolumn{2}{|c|}{ Maximum Load [kW] } & \multicolumn{4}{|c|}{ Increase Due to Leakage [\%] } \\
\hline & & $\begin{array}{c}\text { Supply } \\
\text { Fan }\end{array}$ & $\begin{array}{c}\text { VAV } \\
\text { Boxes }\end{array}$ & $\begin{array}{l}\text { Zone } \\
\text { Supply }\end{array}$ & Avg & RMS & \multirow{2}{*}{$\begin{array}{l}\begin{array}{c}\text { Cooling } \\
\text { Coil }\end{array} \\
\text { nstream }\end{array}$} & \multirow{2}{*}{$\begin{array}{c}\text { Reheat } \\
\text { Coils }\end{array}$} & \multirow[t]{2}{*}{$\begin{array}{c}\text { Supply } \\
\text { Fan }\end{array}$} & \multirow[t]{2}{*}{$\begin{array}{l}\text { VAV } \\
\text { Boxes }\end{array}$} & \multirow[t]{2}{*}{$\begin{array}{c}\text { Cooling } \\
\text { Coil }\end{array}$} & \multirow[t]{2}{*}{$\begin{array}{l}\text { Reheat } \\
\text { Coils }\end{array}$} \\
\hline & & \multicolumn{5}{|c|}{$10+10$ (Upstream + Downstream) Leaks } & & & & & & \\
\hline & Old & 14,615 & 13,311 & 11,980 & 0.57 & 0.13 & 138 & 77 & 16 & 8 & 8 & 5 \\
\hline 3 & New & 14,513 & 13,212 & 11,891 & 0.57 & 0.14 & 134 & 69 & 16 & 8 & 8 & 5 \\
\hline & $\mathrm{T} 24$ & 11,317 & 10,264 & 9,238 & 0.62 & 0.13 & 119 & 59 & 17 & 8 & 8 & 6 \\
\hline & Old & 18,078 & 15,956 & 14,361 & 0.59 & 0.09 & 155 & 52 & 19 & 8 & 77 & 2 \\
\hline 9 & New & 17,988 & 15,612 & 14,051 & 0.63 & 0.07 & 160 & 54 & 21 & 8 & 12 & 2 \\
\hline & $\mathrm{T} 24$ & 12,756 & 11,235 & 10,111 & 0.65 & 0.09 & 141 & 38 & 19 & 8 & 9 & 4 \\
\hline \multirow{7}{*}{12} & Old & 17,463 & $\begin{array}{c}15,774 \\
\end{array}$ & 14,197 & 0.58 & 0.12 & 175 & 99 & 17 & 8 & 8 & 6 \\
\hline & New & 17,001 & 15,363 & 13,826 & 0.58 & 0.13 & 169 & 86 & 17 & 8 & 8 & 5 \\
\hline & T24 & 11,719 & 10,503 & 9,453 & 0.65 & 0.12 & 142 & 53 & 18 & 8 & 9 & 5 \\
\hline & & & & Avg & $\overline{0.61}$ & 0.11 & & & 18 & 8 & 9 & 4 \\
\hline & & & & Min & 0.57 & 0.07 & & & 16 & 8 & 7 & 2 \\
\hline & & & & Max & 0.65 & 0.14 & & & 21 & 8 & 12 & 6 \\
\hline & & \multicolumn{11}{|c|}{$7.5+7.5$ (Upstream + Downstream) Leaks } \\
\hline & Old & 13,877 & 12,951 & 11,980 & 0.57 & 0.13 & 134 & 75 & 10 & 5 & 5 & 3 \\
\hline 3 & New & 13,779 & 12,855 & 11,891 & 0.58 & 0.13 & 131 & 68 & 10 & 5 & 5 & 3 \\
\hline & T24 & 10,735 & 9,987 & 9,238 & 0.62 & 0.13 & 116 & 58 & 11 & 5 & 5 & 4 \\
\hline & "Old & $\bar{~} 17,031$ & 715,525 & $\bar{~} 14,361$ & 0.60 & $\begin{array}{l}0.08 \\
\end{array}$ & $\bar{~} 151$ & $\bar{~} 52$ & $\overline{12}$ & $\overline{5}$ & $\bar{~} 5$ & $\overline{11}$ \\
\hline 9 & New & 16,877 & 15,190 & 14,051 & 0.64 & 0.07 & 149 & 54 & 13 & 5 & 5 & 1 \\
\hline & T24 & 12,011 & 10,931 & 10,111 & 0.66 & 0.09 & 137 & 37 & 12 & 5 & 6 & 2 \\
\hline \multirow{7}{*}{12} & "Old & 10.547 & $=15,348$ & $\overline{14} 14,197$ & 0.58 & 0.12 & $\overline{c 170}$ & 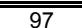 & $\bar{~} 11$ & $\overline{5}$ & $\bar{~} 5$ & 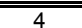 \\
\hline & New & 16,110 & 14,947 & 13,826 & 0.58 & 0.13 & 164 & 85 & 11 & 5 & 5 & 3 \\
\hline & T24 & 11,083 & 10,219 & 9,453 & 0.65 & 0.12 & 137 & 52 & 11 & 5 & 6 & 3 \\
\hline & & & & Avg & 0.61 & 0.11 & & & 11 & 5 & 5 & 3 \\
\hline & & & & Min & 0.57 & 0.07 & & & 10 & 5 & 5 & 1 \\
\hline & & & & Max & 0.66 & 0.13 & & & 13 & 5 & 6 & 4 \\
\hline & & \multicolumn{11}{|c|}{$10+2.5$ (Upstream + Downstream) Leaks } \\
\hline \multirow{3}{*}{3} & Old & 13,491 & 12,287 & 11,980 & 0.58 & 0.12 & 133 & 73 & 7 & 0 & 4 & 0 \\
\hline & New & 13,396 & 12,196 & 11,891 & 0.58 & 0.13 & 130 & 66 & 7 & 0 & 4 & 0 \\
\hline & T24 & 10,447 & 9,475 & 9,238 & 0.63 & 0.12 & 115 & 56 & 8 & 0 & 4 & 0 \\
\hline \multirow{3}{*}{9} & Old & 16,687 & 14,729 & 14,361 & 0.61 & 0.08 & 151 & $\overline{51}$ & 10 & 0 & $\overline{5}$ & 0 \\
\hline & New & 16,605 & 14,411 & 14,051 & 0.66 & 0.06 & 152 & 53 & 11 & 0 & 7 & 0 \\
\hline & T24 & 11,775 & 10,370 & 10,111 & 0.67 & 0.08 & 137 & 36 & 10 & 0 & 5 & 0 \\
\hline & 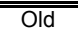 & $\bar{~} 16,120$ & $=714,561$ & 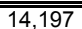 & $\overline{c 0.59}$ & $\overline{c 0.11}$ & $\overline{c 169}$ & 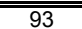 & $\overline{8}$ & $\overline{0}$ & 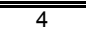 & $\overline{0}$ \\
\hline 12 & New & 15,693 & 14,181 & 13,826 & 0.59 & 0.12 & 163 & 82 & 8 & 0 & 4 & 0 \\
\hline & T24 & 10,818 & 9,695 & 9,453 & 0.66 & 0.11 & 136 & 51 & 9 & 0 & 5 & 0 \\
\hline & & & & Avg & 0.62 & 0.10 & & & 9 & 0 & 5 & 0 \\
\hline & & & & Min & 0.58 & 0.06 & & & 7 & 0 & 4 & 0 \\
\hline & & & & Max & 0.67 & 0.13 & & & 11 & 0 & 7 & 0 \\
\hline
\end{tabular}


Table IV-1b. Leakage Impacts on Equipment Sizing

\begin{tabular}{|c|c|c|c|c|c|c|c|c|c|c|c|c|}
\hline \multirow{2}{*}{\multicolumn{2}{|c|}{ CZ Vintage }} & \multicolumn{3}{|c|}{ Maximum Airflows [scfm] } & \multicolumn{2}{|c|}{ Zone Part Load Flow Ratio } & \multicolumn{2}{|c|}{ Maximum Load [kW] } & \multicolumn{4}{|c|}{ Increase Due to Leakage [\%] } \\
\hline & & $\begin{array}{l}\text { Supply } \\
\text { Fan }\end{array}$ & $\begin{array}{l}\text { VAV } \\
\text { Boxes }\end{array}$ & $\begin{array}{l}\text { Zone } \\
\text { Supply }\end{array}$ & Avg & RMS & $\begin{array}{c}\text { Cooling } \\
\text { Coil }\end{array}$ & $\begin{array}{c}\text { Reheat } \\
\text { Coils }\end{array}$ & \multirow[t]{2}{*}{$\begin{array}{c}\text { Supply } \\
\text { Fan }\end{array}$} & \multirow[t]{2}{*}{$\begin{array}{l}\text { VAV } \\
\text { Boxes }\end{array}$} & \multirow[t]{2}{*}{$\begin{array}{l}\text { Cooling } \\
\text { Coil }\end{array}$} & $\begin{array}{l}\text { Reheat } \\
\text { Coils }\end{array}$ \\
\hline & & \multicolumn{8}{|c|}{$2.5+10$ (Upstream + Downstream) Leaks } & & & \\
\hline & Old & 13,612 & 13,311 & 11,980 & 0.57 & 0.13 & 132 & 77 & 8 & 8 & 3 & 5 \\
\hline 3 & New & 13,512 & 13,212 & 11,891 & 0.57 & 0.14 & 129 & 69 & 8 & 8 & 3 & 5 \\
\hline & T24 & 10,507 & 10,264 & 9,238 & 0.62 & 0.13 & 114 & 59 & 8 & 8 & 4 & 6 \\
\hline \multirow{3}{*}{9} & 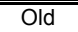 & 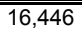 & 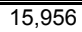 & 14,361 & 0.59 & 0.09 & 148 & $\overline{52}$ & $\overline{88}$ & 8 & $\overline{3}$ & 2 \\
\hline & New & 16,160 & 15,612 & 14,051 & 0.63 & 0.07 & 143 & 54 & 8 & 8 & 1 & 2 \\
\hline & $\mathrm{T} 24$ & 11,586 & 11,235 & 10,111 & 0.65 & 0.09 & 134 & 38 & 8 & 8 & 3 & 4 \\
\hline \multirow{3}{*}{12} & Old & 16,164 & 15,774 & 14,197 & 0.58 & 0.12 & 167 & 99 & 8 & 8 & 4 & 6 \\
\hline & New & 15,741 & 15,363 & 13,826 & 0.58 & 0.13 & 161 & 86 & 8 & 8 & 3 & 5 \\
\hline & T24 & 10,784 & 10,503 & 9,453 & 0.65 & 0.12 & 134 & 53 & 8 & 8 & 4 & 5 \\
\hline & & & & $\overline{A v g}$ & 0.61 & 0.11 & & & 8 & 8 & 3 & 4 \\
\hline & & & & Min & 0.57 & 0.07 & & & 8 & 8 & 1 & 2 \\
\hline & & & & Max & 0.65 & 0.14 & & & 8 & 8 & 4 & 6 \\
\hline & & \multicolumn{11}{|c|}{$5+5$ (Upstream + Downstream) Leaks } \\
\hline \multirow{3}{*}{3} & Old & 13,195 & 12,610 & 11,980 & 0.58 & 0.13 & 131 & 74 & 5 & 3 & 2 & 1 \\
\hline & New & 13,101 & 12,517 & 11,891 & 0.58 & 0.13 & 127 & 67 & 5 & 3 & 2 & 1 \\
\hline & $\mathrm{T} 24$ & 10,197 & 9,724 & 9,238 & 0.62 & 0.13 & 113 & 57 & 5 & 3 & 3 & 2 \\
\hline \multirow{3}{*}{9} & Old & 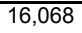 & $\bar{~} 15,116$ & $\overline{~ 14,361}$ & 0.61 & 0.08 & 147 & $\overline{51}$ & 6 & 3 & 2 & 1 \\
\hline & New & 15,857 & 14,790 & 14,051 & 0.65 & 0.06 & 145 & 54 & 6 & 3 & 2 & 1 \\
\hline & $\mathrm{T} 24$ & 11,326 & 10,643 & 10,111 & 0.66 & 0.09 & 133 & 37 & 6 & 3 & 3 & 1 \\
\hline \multirow{3}{*}{12} & Old & 15,702 & 14,944 & 14,197 & 0.58 & 0.12 & 166 & 95 & 5 & 3 & 3 & 2 \\
\hline & New & 15,289 & 14,554 & 13,826 & 0.59 & 0.12 & 160 & 83 & 5 & 3 & 3 & 2 \\
\hline & T24 & 10,496 & 9,951 & 9,453 & 0.66 & 0.11 & 133 & 51 & 5 & 3 & 3 & 1 \\
\hline & & & & $\overline{A v g}$ & 0.61 & 0.11 & & & 5 & 3 & 2 & 1 \\
\hline & & & & Min & 0.58 & 0.06 & & & 5 & 3 & 2 & 1 \\
\hline & & & & Max & 0.66 & 0.13 & & & 6 & 3 & 3 & 2 \\
\hline & & & & $2.5+2$ & pstream & eam) Lea & & & & & & \\
\hline & Old & 12,565 & 12,287 & 11,980 & 0.58 & 0.12 & 128 & 73 & & & & \\
\hline 3 & New & 12,473 & 12,196 & 11,891 & 0.58 & 0.13 & 125 & 66 & & & & \\
\hline & $\mathrm{T} 24$ & 9,699 & 9,475 & 9,238 & 0.63 & 0.12 & 110 & 56 & & & & \\
\hline & "Old & $\bar{~} 15,181$ & $\overline{c 14,729}$ & $\bar{~} 14,361$ & 0.61 & 0.08 & 144 & 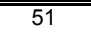 & & & & \\
\hline 9 & New & 14,917 & 14,411 & 14,051 & 0.66 & 0.06 & 142 & 53 & & & & \\
\hline & T24 & 10,695 & 10,370 & 10,111 & 0.67 & 0.08 & 130 & 36 & & & & \\
\hline & Old & $\overline{14,921}$ & $\bar{~} 14,561$ & 14,197 & 0.59 & 0.11 & 162 & 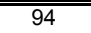 & & & & \\
\hline 12 & New & 14,530 & 14,181 & 13,826 & 0.59 & 0.12 & 156 & 82 & & & & \\
\hline & T24 & 9,954 & 9,695 & 9,453 & 0.66 & 0.11 & 130 & 51 & & & & \\
\hline & & & & $\overline{A v g}$ & 0.62 & 0.10 & & & & & & \\
\hline & & & & Min & 0.58 & 0.06 & & & & & & \\
\hline & & & & Max & 0.67 & 0.13 & & & & & & \\
\hline
\end{tabular}


APPENDIX V: OPERATING COST IMPACTS

Table V-1a. Leakage Impacts on Annual HVAC System Operating Costs

\begin{tabular}{|c|c|c|c|c|c|c|c|c|c|c|c|}
\hline & \multicolumn{4}{|c|}{ Annual Operating Cost [\$] } & \multicolumn{6}{|c|}{ Cost Increase Due to Leakage } \\
\hline & & \multirow{2}{*}{$\begin{array}{l}\text { Both } \\
\text { Fans }\end{array}$} & \multirow[b]{2}{*}{ Cooling } & \multirow[b]{2}{*}{ Heating } & \multirow[b]{2}{*}{ Total } & \multirow{2}{*}{$\begin{array}{c}\text { Fans } \\
\$ / y r\end{array}$} & \multirow{2}{*}{$\begin{array}{c}\text { Cooling } \\
\$ / y r\end{array}$} & \multirow{2}{*}{$\begin{array}{l}\text { Heating } \\
\$ / y r\end{array}$} & \multicolumn{3}{|c|}{ Total } \\
\hline $\mathrm{CZ}$ & Vintage & & & & & & & & $\$ / y r$ & $\%$ & $\$ / \mathrm{ft} 2$ \\
\hline & & \multicolumn{10}{|c|}{$10+10$ (Upstream + Downstream) Leaks } \\
\hline \multirow{3}{*}{3} & Old & 18,754 & 36,907 & 8,088 & 63,749 & 6,170 & 3,457 & -390 & 9,237 & 17 & 0.18 \\
\hline & New & 18,721 & 36,227 & 7,435 & 62,383 & 6,172 & 3,320 & -445 & 9,047 & 17 & 0.17 \\
\hline & $\mathrm{T} 24$ & 16,134 & 31,793 & 4,842 & 52,769 & 5,409 & 2,994 & -198 & 8,204 & 18 & 0.16 \\
\hline \multirow{3}{*}{9} & Old & 17,848 & 62,643 & 12,523 & 93,014 & 5,376 & 4,533 & $-1,422$ & 8,487 & 10 & 0.16 \\
\hline & New & 17,694 & 60,689 & 16,127 & 94,510 & 5,049 & 4,264 & $-1,837$ & 7,475 & 9 & 0.14 \\
\hline & T24 & 14,598 & 49,836 & 6,178 & 70,611 & 4,658 & 3,299 & -605 & 7,352 & 12 & 0.14 \\
\hline \multirow{3}{*}{12} & Old & 20,489 & $\overline{52,490}$ & $\overline{c 13,851}$ & 86,831 & $\begin{array}{ll}6,638 \\
\end{array}$ & $\overline{3,334}$ & -435 & 9,538 & 12 & 0.18 \\
\hline & New & 20,254 & 50,630 & 12,508 & 83,392 & 6,592 & 3,163 & -506 & 9,249 & 12 & 0.18 \\
\hline & T24 & 15,782 & 42,077 & 6,715 & 64,574 & 5,249 & 2,675 & -283 & 7,642 & 13 & 0.15 \\
\hline & & & & Avg & 74,648 & 5,701 & 3,449 & -680 & 8,470 & 13 & 0.16 \\
\hline & & & & Min & 52,769 & 4,658 & 2,675 & $-1,837$ & 7,352 & 9 & 0.14 \\
\hline & & & & Max & 94,510 & 6,638 & 4,533 & -198 & 9,538 & 18 & 0.18 \\
\hline & & \multicolumn{10}{|c|}{$7.5+7.5$ (Upstream + Downstream) Leaks } \\
\hline \multirow{3}{*}{3} & Old & 16,270 & 35,594 & 8,217 & 60,081 & 3,685 & 2,145 & -261 & 5,569 & 10 & 0.11 \\
\hline & New & 16,235 & 35,014 & 7,583 & 58,832 & 3,686 & 2,107 & -298 & 5,496 & 10 & 0.10 \\
\hline & $\mathrm{T} 24$ & 13,958 & 30,662 & 4,908 & 49,528 & 3,233 & 1,862 & -132 & 4,963 & 11 & 0.09 \\
\hline \multirow{3}{*}{9} & Old & $\overline{15,631}$ & 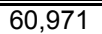 & 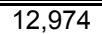 & $\overline{c 89,576}$ & 3,159 & $\overline{22,861}$ & -970 & $\overline{c 5,050}$ & 6 & 0.10 \\
\hline & New & 15,602 & 58,853 & 16,724 & 91,178 & 2,957 & 2,427 & $-1,240$ & 4,144 & 5 & 0.08 \\
\hline & $\mathrm{T} 24$ & 12,689 & 48,618 & 6,378 & 67,685 & 2,750 & 2,081 & -405 & 4,426 & 7 & 0.08 \\
\hline \multirow{3}{*}{12} & Old & $\overline{177,803}$ & $\overline{51,262}$ & 13,997 & 83,062 & $3,3,952$ & $\overline{2,106}$ & -289 & $\overline{5,769}$ & 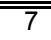 & 0.11 \\
\hline & New & 17,588 & 49,465 & 12,674 & 79,726 & 3,925 & 1,999 & -340 & 5,583 & 8 & 0.11 \\
\hline & T24 & 13,659 & 41,103 & 6,808 & 61,569 & 3,126 & 1,701 & -191 & 4,637 & 8 & 0.09 \\
\hline & & & & Avg & 71,249 & 3,386 & 2,143 & -458 & 5,071 & 8 & 0.10 \\
\hline & & & & Min & 49,528 & 2,750 & 1,701 & $-1,240$ & 4,144 & 5 & 0.08 \\
\hline & & & & Max & 91,178 & 3,952 & 2,861 & -132 & 5,769 & 11 & 0.11 \\
\hline & & \multicolumn{10}{|c|}{$10+2.5$ (Upstream + Downstream) Leaks } \\
\hline \multirow{3}{*}{3} & Old & 15,967 & 35,402 & 8,477 & 59,846 & 3,382 & 1,953 & -1 & 5,334 & 10 & 0.10 \\
\hline & New & 15,916 & 34,828 & 7,880 & 58,624 & 3,368 & 1,921 & -1 & 5,288 & 10 & 0.10 \\
\hline & $\mathrm{T} 24$ & 13,606 & 30,467 & 5,039 & 49,113 & 2,881 & 1,668 & -1 & 4,548 & 10 & 0.09 \\
\hline \multirow{3}{*}{9} & Old & 15,953 & 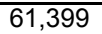 & $\overline{113,943}$ & 91,295 & 3,480 & 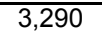 & -1 & 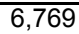 & 8 & 0.13 \\
\hline & New & 16,124 & 59,437 & 17,963 & 93,523 & 3,479 & 3,012 & -1 & 6,489 & 7 & 0.12 \\
\hline & $\mathrm{T} 24$ & 12,747 & 48,672 & 6,782 & 68,201 & 2,808 & 2,135 & 0 & 4,942 & 8 & 0.09 \\
\hline \multirow{3}{*}{12} & OId & 177,665 & $\overline{c 51,120}$ & 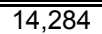 & 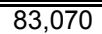 & $3 \overline{3,814}$ & $\overline{c 1,965}$ & $\overline{-1-2}$ & 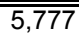 & $\overline{77}$ & 0.11 \\
\hline & New & 17,413 & 49,302 & 13,013 & 79,728 & 3,751 & 1,836 & -1 & 5,585 & 8 & 0.11 \\
\hline & T24 & 13,449 & 40,939 & 6,997 & 61,385 & 2,916 & 1,537 & -1 & 4,452 & 8 & 0.08 \\
\hline & & & & $\overline{A v g}$ & 71,643 & 3,320 & 2,146 & $\overline{-1}$ & $\overline{5,465}$ & 8 & 0.10 \\
\hline & & & & Min & 49,113 & 2,808 & 1,537 & -2 & 4,452 & 7 & 0.08 \\
\hline & & & & Max & 93,523 & 3,814 & 3,290 & 0 & 6,769 & 10 & 0.13 \\
\hline
\end{tabular}


Table V-1b. Leakage Impacts on Annual HVAC System Operating Costs

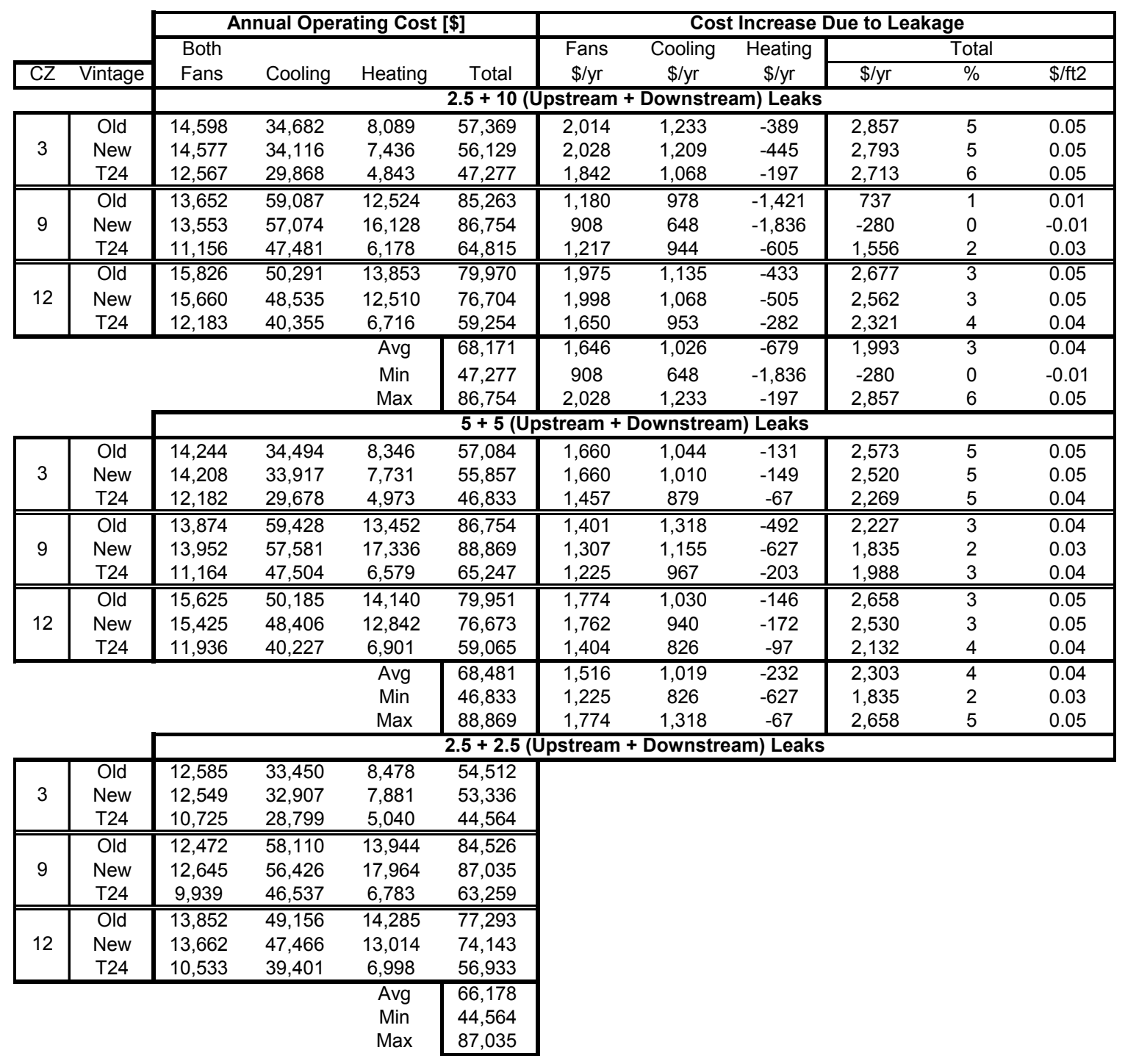

